UNIVERSIDADE DE SÃO PAULO

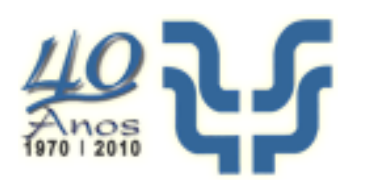

INSTITUTO DE PSICOLOGIA

ISABELLA BERTELLI CABRAL DOS SANTOS

Desconto do futuro e percepção de tempo

São Paulo

2012 
ISABELLA BERTELLI CABRAL DOS SANTOS

\title{
Desconto do futuro e percepção de tempo
}

\author{
Dissertação de Mestrado apresentada ao Instituto de Psicologia \\ da Universidade de São Paulo, como parte dos requisitos para obtenção \\ de título de Mestre em Psicologia.
}

Área de Concentração: Psicologia Experimental - Comportamento Animal.

Orientadora: Profa. Dra. Vera Silvia Raad Bussab

São Paulo

2012 


\section{AUTORIZO A REPRODUÇÃO E DIVULGAÇÃO TOTAL OU PARCIAL DESTE TRABALHO, POR QUALQUER MEIO CONVENCIONAL OU ELETRÔNICO, PARA FINS DE ESTUDO E PESQUISA, DESDE QUE CITADA A FONTE.}

\section{Catalogação na publicação}

Biblioteca Dante Moreira Leite

Instituto de Psicologia da Universidade de São Paulo

Santos, Isabella Bertelli Cabral dos.

Desconto do futuro e percepção de tempo / Isabella Bertelli Cabral dos Santos; orientadora Vera Silvia Raad Bussab. -- São Paulo, 2012.

$94 \mathrm{f}$.

Dissertação (Mestrado - Programa de Pós-Graduação em Psicologia. Área de Concentração: Psicologia Experimental) - Instituto de Psicologia da Universidade de São Paulo.

1. Psicologia cognitiva 2. Percepção de tempo 3. Desconto do futuro I. Título. 
Nome: Santos, Isabella Bertelli Cabral

Título: Desconto do futuro e percepção de tempo

Dissertação de Mestrado apresentada ao Instituto de Psicologia da Universidade de São Paulo para obtenção de título de Mestre em Psicologia.

Aprovado em:

Banca Examinadora

Prof. Dr.:

Instituição:

Assinatura:

Prof. Dr.:

Instituição:

Assinatura:

Prof. Dr.:

Instituição:

Assinatura: 
"O tempo é o maior tesouro de que um homem pode dispor; embora inconsumível, o tempo é o nosso melhor alimento; sem medida que o conheça, o tempo é contudo nosso bem de maior grandeza: não tem começo, não tem fim; rico não é o homem que coleciona e se pesa num amontoado de moedas, nem aquele, devasso, que estende, mãos e braços, em terras largas; rico só é o homem que aprendeu, piedoso e humilde, a conviver com o tempo, aproximando-se dele com ternura, não se rebelando contra o seu curso, brindando-o antes com sabedoria para receber dele os favores e não sua ira; o equilíbrio da vida está essencialmente deste bem supremo, e quem souber com acerto a quantidade de vagar, ou a de espera, que se deve pôr nas coisas, não corre nunca o risco, ao buscar por elas, de defrontar-se com o que não é; pois só a justa medida do tempo dá a justa natureza das coisas."

Monólogo de Raul Cortez no final de Lavoura Arcaica (filme dirigido por Luiz Fernando Carvalho). O texto (adaptado) é do livro de mesmo nome, de Raduan Nassar. 


\section{RESUMO}

SANTOS, I.B.C. (2011). Desconto do futuro e percepção de tempo. Dissertação de Mestrado, Instituto de Psicologia, Universidade de São Paulo, São Paulo.

A tomada de decisão quase sempre envolve a dimensão temporal e no ser humano, como nos outros animais, há um viés em favorecer o presente, fenômeno chamado de desconto do futuro. Entender em que condições e contextos os vieses cognitivos como o desconto do futuro ocorrem nos ajuda a compreender o funcionamento da cognição humana, e pode fornecer caminhos para prevenir a sua ocorrência quando são prejudiciais. Há pouco consenso sobre os antecedentes psicológicos do desconto do futuro, e o nível em que ele ocorre varia conforme a espécie, o sexo, a idade, os indivíduos, e os diferentes contextos para o mesmo indivíduo. Há poucos estudos que investigam a relação entre escolhas intertemporais e a percepção subjetiva do tempo. Para compreender o fenômeno do desconto do futuro e os mecanismos psicológicos relacionados a ele, nesse estudo investigamos a influência da percepção subjetiva de tempo. Participaram 208 pessoas, 117 mulheres e 91 homens com idades entre 18 e 71 anos, que responderam a um questionário online, anônima e voluntariamente. Foram perguntados o gênero, a idade, escolaridade, estado civil, se o participante possuía ou não filhos e em seguida o participante respondia a quatro instrumentos: (1) “Cenário do Cupom”, para verificar a taxa de desconto do futuro, com quatro condições experimentais que corresponderam a diferentes modos de apresentação do intervalo de tempo de três meses, (2) “Aversão ao Risco”, para verificar a aversão ao risco e (3) "Distância da data” e (4) “Zimbardo Time Perspective Inventory - ZTPI, para verificar a percepção subjetiva de tempo. Não foi encontrada diferença significativa na taxa de desconto do futuro entre as quatro condições experimentais, contudo foi encontrada uma correlação positiva entre taxa de desconto do futuro e distância subjetiva da data em geral, juntando-se os quatro grupos e independente da apresentação. As análises indicaram que as mulheres dessa amostra apresentam maior taxa de desconto do futuro, são mais avessas ao risco, e mais propensas à orientação temporal do futuro. Os jovens, apresentaram, com relação aos mais velhos, maior taxa de desconto do futuro e maior propensão ao tempo presente. Além da distância subjetiva temporal, as variáveis gênero e idade foram as únicas que correlacionaram com diferenças na taxa de desconto do futuro. O instrumento "Cenário do cupom” pode não 
ter sido adequado para acessar a taxa de desconto do futuro dos participantes quando se considera o gênero, já que outros fatores podem ter causado o maior valor pedido, e não uma maior propensão ao presente.

Palavras-chave: Desconto do futuro. Percepção de tempo. Psicologia cognitiva. 
SANTOS, I.B.C. (2011). Future discounting and time perception. Dissertação de Mestrado, Instituto de Psicologia, Universidade de São Paulo, São Paulo.

Every moment we have to decide, and during this process cognitive biases can occur. Decision making almost always includes the temporal dimension. Human beings and other animals prefer the present, phenomenon known as future discounting. There is almost no consensus about the psychological antecedents of future discounting. Its occurrence varies with the species, the individual, the gender, the age, and different contexts for the same individual. We can understand the functioning of human mind studying the cognitive biases and the context of their occurrence, moreover we can prevent their occurrence when they are prejudicial. There are not many studies on intertemporal choice and time perception, therefore we want to contribute to the literature, adding data and reflections in this area. We explored the time perception, trough four experimental conditions, and controlling gender, age, marital status and if the participant had children or not. We had 208 participants, 117 women and 91 men, ages varying from 18 and 71, which answered to an anonymous online questionnaire, voluntarily. There were four instruments, one to verify the discounting future rate ("Gift certificate Scenario” ) with four experimental conditions corresponding to four different ways of presenting the three months interval, one to verify risk aversion ("Risk aversion"), and two to verify time perception ("Distance to the date", "Zimbardo time perspective inventory"). There was no difference in the four experimental conditions; women had a higher future discounting rate than men, and younger participants had a higher discounting rate than older participants. Women were more risk averse than men. Younger participants had more propensity to the present than older participants. Women had more propensity to the future than men. The higher the discounting rate, higher the subjective distance of the date. There were no influence of the way the date is present, neither the participant's marital status or if the participant had children or not. Age and gender showed an influence in time perception and future discounting.

Key Words: Future discounting. Time perception. Cognitive psychology. Evolutionary psycology.

\section{SUMÁRIO}




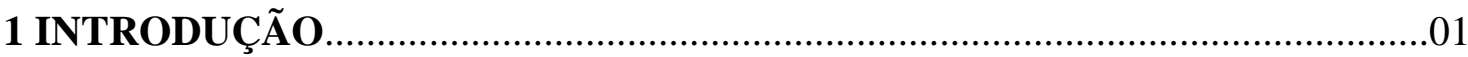

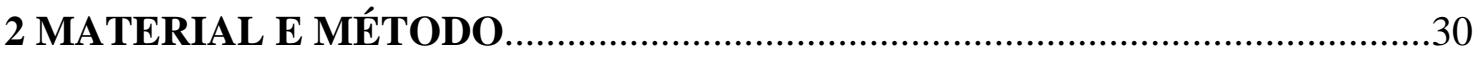

3 RESULTADOS............................................................................................

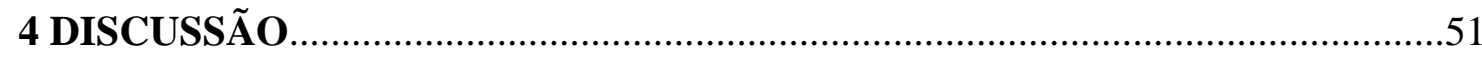

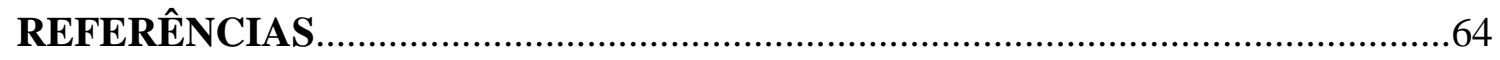

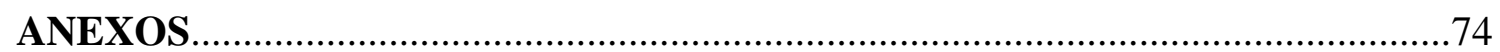

ÍNDICE 


\section{INTRODUÇÃO}

1.1 Tomada de decisão e vieses cognitivos................................................................

1.2 Escolhas intertemporais: desconto do futuro.................................................

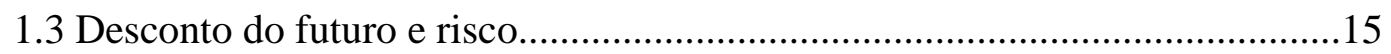

1.4 Antecedentes psicológicos do desconto do futuro.........................................19

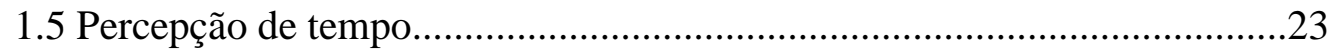

1.6 Desconto do futuro e percepção de tempo....................................................27

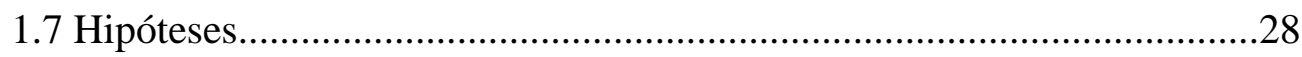

\section{MATERIAL E MÉTODO}

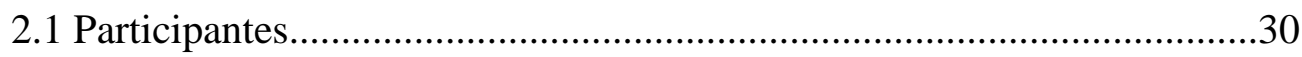

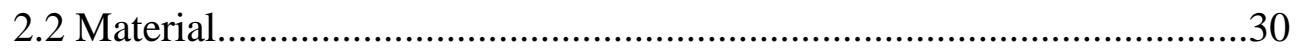

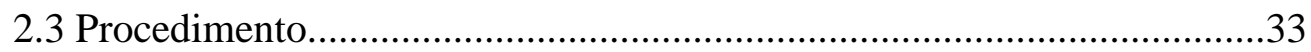

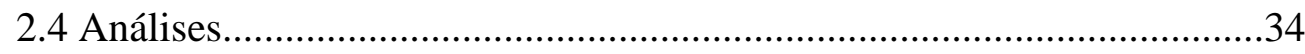

\section{ANÁLISES}

3.1 Análise descritiva geral..........................................................................36

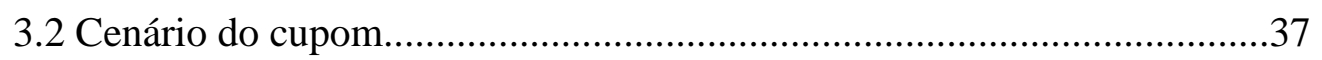

3.3 Distância da data......................................................................................41

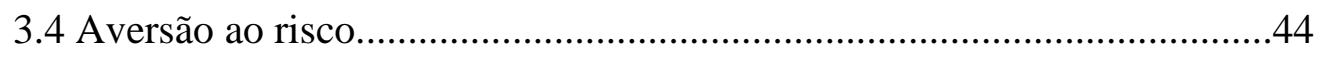

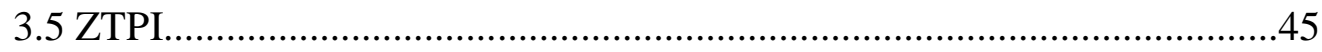

\section{DISCUSSÃO}

4.1 Retomada dos resultados........................................................................51

4.2 Diferenças de gênero.................................................................................52

4.3 Diferenças de idade...................................................................................5

4.4 Diferenças na percepção subjetiva temporal entre os quatro grupos experimentais em "distância da data"..... 
4.5 Desconto do futuro e distância subjetiva da data.......................................58

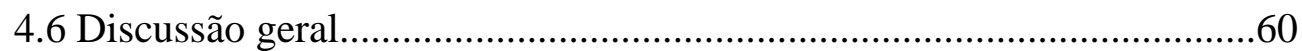

4.7 Reflexões sobre o método....................................................................62

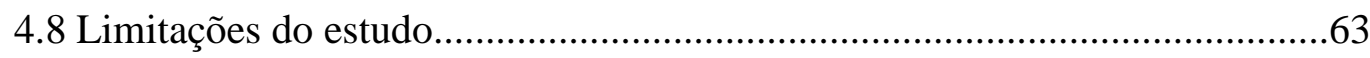

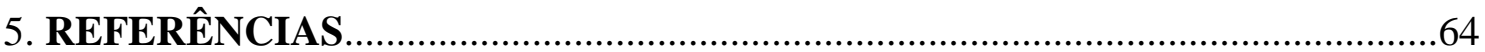

\section{ANEXOS}

ANEXO A - Aprovação do Comitê de Ética...................................................................74

ANEXO B - Termo de consentimento livre e esclarecido e material metodológico.......75 


\section{INTRODUÇÃO}

\subsection{Tomada de decisão e vieses cognitivos}

Decidir é o processo de escolha de um dentre vários cenários alternativos e ocorre a quase todo momento. O processo de decisão envolve tanto situações cotidianas do indivíduo como que roupa vestir quanto maiores como se casar agora ou esperar, ou mesmo decisões em escalas maiores que a individual, como a decisão política de investir ou não em educação.

O estudo da tomada de decisão foi inicialmente influenciado pela economia, em que a teoria da utilidade econômica predominava (Baron, 2008). A teoria, inserida no modelo moderno de finanças da década de 1970, pressupunha um modelo de agente racional. O ser humano era visto como um ser racional que tomava decisões de modo a maximizar as conseqüências desejadas, por exemplo, no contexto financeiro, esperava-se que as decisões levassem à posse de uma quantia maior de dinheiro (Thaler, 2000).

Na teoria da utilidade econômica, "utilidade” se referia às conseqüências desejadas pelas pessoas (Manktellow, 1999), por exemplo, um bom emprego, um carro, amor, dinheiro, respeito, felicidade etc. Foi desenvolvido o modelo normativo que descreve a maximização da utilidade, ou seja, que atitudes as pessoas deveriam tomar para que seus objetivos fossem alcançados (Baron, 2008). Os psicólogos começaram a se interessar pelo tema por volta de 1950 (Baron, 2008), e os estudos na área de comportamento e cognição ganharam uma importante contribuição com os trabalhos de Tversky e Kahneman (1974, Kahneman \& Tversky, 1979).

Tversky e Kahneman (1974, Kahneman \& Tversky, 1979) realizaram estudos sobre o processamento de informações na tomada de decisão e criaram o conceito de "vieses cognitivos", e o campo de pesquisas que inauguraram ficou conhecido como "Heurísticas e vieses”. Para os autores, em grande parte das situações cotidianas, o tempo para decisões é limitado e a energia gasta na cognição não pode ser alta todo o tempo. Além disso, os problemas a ser enfrentados podem ser complexos, as informações disponíveis podem ser incompletas, e não há certeza das conseqüências das decisões a serem tomadas, daí a denominação feita pelos autores de "tomada de decisão sob incerteza”. Os autores descreveram um processamento rápido que ocorreria através de atalhos cognitivos.As 
heurísticas são atalhos mentais, que quando levam a erros sistemáticos são chamadas de vieses. Para esse campo teórico, os vieses são assim chamados porque desviam de um padrão de comparação considerado o correto, no caso, o dos padrões normativos da lógica e da teoria da probabilidade. Uma lista de vieses cognitivos foi criada, e desde então vieses descritos por outros pesquisadores têm sido adicionados àqueles definidos por Tversky e Kahneman.

Esses autores investigaram a cognição humana através de experimentos simples. Por exemplo, quando perguntaram a pessoas qual sequência era mais provável ao se jogar moedas $($ cara $=$ A e coroa $=0$ ), a sequência AOAOOA foi julgada como mais provável de ocorrer do que as sequências AAAOOO e AAAAOA. Apesar de todas serem igualmente prováveis, a primeira, por conter alternações, parece mais representativa de uma série aleatória e assim parece ser a mais provável (Tversky \& Kahneman, 1983).

Pediram também a voluntários que lessem o perfil de uma mulher, e que depois julgassem qual dos dois cenários era mais provável (Tversky \& Kahnemann, 1983). "Linda tem 31 anos, é solteira, é sincera e muito inteligente. Ela se formou em filosofia. Quando estudante, era muito preocupada com questões de discriminação e justiça social e participou de protestos anti-nucleares.” As duas opções eram - 1) Linda é caixa de banco. 2) Linda é caixa de banco e participa do movimento feminista. Cerca de $80 \%$ dos participantes responderam que a segunda opção era a mais provável. Porém, matematicamente, uma conjunção, ou seja, uma operação com dois constituintes, não pode ser mais provável do que a operação contendo somente um dos constituintes. O viés ficou conhecido como "falácia da conjunção” (conjunction fallacy). Possíveis explicações para a resposta dos participantes envolvem o conceito de representatividade, em que as pessoas tendem a escolher a resposta que mais lhes parece representativa da situação.

Tversky e Kahneman (1974) pediram a participantes que estimassem a quantidade em percentual do total de países africanos presentes na Organização das Nações Unidas. Determinaram que um número entre zero e 100 fosse estabelecido através de uma roleta da fortuna, e primeiramente os sujeitos deveriam dizer se o número de países africanos presentes na ONU era maior ou menor do que o número indicado pela roleta, ajustando para cima ou para baixo. E num próximo passo, estimar a quantidade sem considerar o número da roleta. Mesmo com a instrução de ignorar o número da roleta, os participantes no segundo momento estimaram números próximos aos sorteados na roleta, ainda que para um grupo o número 
tenha sido extremamente baixo, e para outro, bastante alto, como se não conseguissem não usar o número sorteado como âncora, ainda que ele fosse absurdo nessa situação.

O viés da ancoragem (anchoring bias) foi então descrito como esse ajustamento de nossa estimativa numérica a respeito de algo com base em uma âncora arbitrária. Assim se for necessário estimar o valor de algo depois de recebermos uma informação de um valor (âncora), ele será enviesado pela âncora, mesmo que essa âncora seja um número arbitrário.

O excesso de confiança (overconfidence) foi também descrito como um viés. Nele, as pessoas quase sempre se julgam acima da média em alguma característica perguntada, mesmo que em geral a média seja altamente representativa. Em geral esse viés é mais forte em características que envolvem alguma habilidade, como por exemplo, se a pessoa é bom motorista, se tem capacidade de liderança, se tem bom relacionamento com as pessoas. Tem sido mais encontrado em homens (Barber \& Odean, 2001).

Também foi descrito o viés de aversão à perda (loss aversion), em que as perdas parecem pesar mais do que os ganhos, de modo que ficamos mais tristes em perder $\mathrm{R} \$ 10,00$ do que ficamos felizes em ganhar R\$10,00. No viés retrospectivo (hindsight bias), julgamos um evento com maior probabilidade de ocorrer depois de saber que ele realmente ocorreu, mesmo que as chances dele ter acontecido fossem as mesmas que de outros eventos (Fischoff \& Beyth, 1975). Depois de saber que certo candidato venceu as últimas eleições, ao voltar no cenário de antes dos resultados, julgamos que a probabilidade desse candidato ganhar era maior do que os números realmente indicavam. É como se não conseguíssemos voltar na época anterior sem levar em conta que não tínhamos a informação de que aquele candidato venceria.

Na ilusão de foco (focusing illusion) a nossa atenção é desviada para apenas um aspecto, que acaba tendo mais importância do que deveria. Foi perguntado a alguns sujeitos quão felizes eram com a vida deles em geral, e quantos encontros amorosos haviam tido no mês passado. Quando a ordem das perguntas era essa, não havia correlação entre as duas respostas, porém quando eram invertidas e a dos encontros era a primeira, havia alta correlação entre as respostas, indicando que houve um foco na questão amorosa dos sujeitos e seu peso foi maior na avaliação da felicidade geral (Strack, Martin \& Schwarz, 1988).

Assim, a noção principal que Kahneman e Tversky estabeleceram era a de que no julgamento e tomada de decisão muitas vezes as pessoas podem se comportar de maneira que 
não as leva a seus objetivos, e uma das causas é que nossos julgamentos intuitivos podem ser enganadores. Esses julgamentos enganadores, contudo, são cometidos de maneiras sistemáticas e regulares, e podem revelar o funcionamento da mente.

Simon (1957), outro importante autor no campo da psicologia cognitiva, explicou a ocorrência desses vieses em termos de racionalidade limitada (bounded rationality), na qual descreve que as pessoas têm limitações no processamento de informações, e tendem a fazer o melhor que podem dadas as limitações a que estão sujeitas. Considera-se que o autor tenha contribuído para uma compreensão da cognição humana mais realista, em que não seríamos completamente racionais e não agiríamos como máquinas perfeitas. Nossa capacidade de processar informações é limitada, portanto em situações de incerteza tendemos a utilizar regras práticas, as heurísticas ou vieses, para tomar decisões (Bettman, Johnson \& Payne, 1991), e que normalmente levam a saídas satisfatórias.

Assim, tanto Tversky e Kahneman quanto Simon apresentam uma alternativa mais realista ao modelo de racionalidade adotado pela economia. Porém, esses autores não rompem totalmente com o modelo de funcionamento lógico, porque colocam ressalvas que ainda sustentam essa noção. O ser humano é visto como uma máquina quase perfeita, cujo propósito é atingir seus objetivos (que seriam conscientes e bem definidos), e as limitações, incluindo os vieses cognitivos, os impediriam de agir com precisão.

Posteriormente, outros autores desenvolveram novas visões, como o neurocientista António Damásio (em “O erro de Descartes”, 1994), que trouxe as emoções ao palco da racionalidade. Com o conceito de marcadores somáticos, mostrou que as emoções não são obstáculos, e sim que são necessárias para um funcionamento socialmente adequado na tomada de decisões.

Somando-se à essa mudança na visão das emoções, estudos recentes têm trabalhado com a noção de inconsciente, trazida inicialmente por Freud e posteriormente modificada de várias maneiras por diferentes linhas teóricas. Na psicologia social muitas pesquisas indicaram que na tomada de decisão existem influências importantes sobre as quais os indivíduos não estão conscientes (Bargh, 2006).

Haselton e colaboradores (2009), em uma crítica semelhante ao modelo do ser humano racional, afirmam que ainda há muitos pesquisadores que acreditam que os vieses cognitivos sejam erros genuínos da cognição humana. Mesmo com a noção de racionalidade limitada, 
ainda se pensa que se não houvesse limitações, como todas as informações estarem disponíveis, ou toda a atenção voltada para o problema, dentre outras, a mente seria um processador de informações perfeito logicamente.

Os autores (Haselton et al., 2009) ressaltam, porém, que a mente humana foi selecionada naturalmente para resolver vários problemas como vida em sociedade, busca de parceiros, cuidados com a prole, alimentação, e não para ser uma máquina de funcionamento lógico. Compreender que tipos de problemas tinham que ser solucionados em nosso ambiente de adaptação evolutiva auxilia no entendimento de como a mente evoluiu para pensar, e, portanto, ajuda também a entender como surgiram os assim denominados vieses. Os problemas ecológicos que a espécie teve que enfrentar provavelmente nos levaram a desenvolver raciocínios efetivos para lidar com eles (Tooby \& DeVore, 1987). Assim, não seriam erros ou vieses, e sim o processamento mental normal necessário para lidar com os problemas evolutivos típicos dos seres humanos.

Cosmides e Tooby, dois dos fundadores da psicologia evolucionista (Tooby \& Cosmides, 1992), consideram a mente mais semelhante a um canivete-suíço, que evoluiu resolvendo problemas específicos do ambiente. A chave para entender a mente, afirmam, é entender o contexto ambiental que a espécie enfrentou durante a evolução (Cosmides \& Tooby, 1994):

Métodos de tomada de decisão racionais... lógica, matemática, teoria da probabilidade... são computacionalmente fracos - incapazes de resolver os problemas adaptativos naturais que nossos ancestrais tiveram que resolver com segurança para poder se reproduzir. Essa performance pobre na maioria dos problemas naturais (pelos métodos considerados racionais) é a razão primária pela qual especializações para a resolução de problemas foram favorecidas pela seleção natural em vez de solucionadores gerais de problemas. Apesar das vastas alegações em contrário, a mente humana não é pior do que racional... mas pode frequentemente ser melhor do que racional. (p. 329).

Para Fodor (2000) não há evidências de que o funcionamento adequado da mente humana seja a busca pela verdade, aqui considerada como o mais próximo do fato ou da realidade. Concordando com o autor, Pinker (2005) afirma que a seleção natural não está comprometida com a busca da verdade por si, e que as crenças de um indivíduo que podem lhe dar vantagens não necessariamente carregam a verdade. Por exemplo, é vantajoso acreditar que seu próprio grupo seja melhor que os outros e especial (Chow, Lowery \& Knowles, 2008 citados em Haselton et al., 2009), e que seu parceiro amoroso é o melhor que existe (Murray, Holmes, Dolderman \& Griffin, 2000 citados em Haselton et al., 2009). 
No processo evolutivo, o que importa é quanto o processamento de informações contribui para a sobrevivência e reprodução, e não o quanto está relacionado com a verdade, embora normalmente a aproximação com a verdade leve a maior sucesso. Um paralelo pode ser feito com nosso sistema visual, que não funciona como uma câmera registrando o mundo como ele é, e apresenta as denominadas ilusões, porém elas normalmente levam a uma maior adaptação ao mundo e raramente causam problemas sérios. Assim, a denominação ilusões visuais pode ser criticada, porque sugere uma distorção, quando na verdade o que nosso sistema visual faz é uma interpretação do ambiente que é vantajosa para nossa espécie, e não pode ser considerada uma distorção porque não há um modelo ao qual se comparar. A comparação com uma câmera de filmagem é pobre, afinal o objetivo da câmera ao filmar é diferente dos propósitos de um ser vivo de certa espécie ao enxergar.

O ponto de partida para entender como a mente funciona pode ser refletir sobre o que ela evoluiu para fazer adequadamente. Haselton e colaboradores (2009) chamam a atenção para o fato de que somos uma espécie muito social, portanto é esperado que consigamos resolver problemas relacionados à vida social, como detecção de trapaceiros (Cosmides \& Tooby, 2005), avaliação de interesse de um parceiro sexual, compreensão e respeito à hierarquia social, identificação de pessoas de fora do grupo etc. As pesquisas na área de psicologia evolucionista têm indicado que somos bons nesses campos, que representam domínios ecológicos válidos, ou seja, situações que tivemos que enfrentar no ambiente de adaptação evolutiva.

Já nas pesquisas do campo da heurística e vieses alguns dos vieses identificados representam situações artificiais. Por exemplo, nos experimentos sobre probabilidade os participantes têm demonstrado um desempenho muito distante com relação ao que seria matematicamente correto (por exemplo, em Tversky \& Kahneman, 1974). Porém, as pesquisas costumam envolver situações artificiais, que pouco têm a ver com os problemas que fomos selecionados para resolver.

Além disso, Haselton e colaboradores (2009) atestam que muitos dos vieses representam, na verdade, erros de gerenciamento (management errors), em que o erro menos custoso é selecionado em vez de um erro mais custoso. Um exemplo é o viés descrito como percepção exagerada de interesse sexual (sexual overperception) por parte dos homens (Haselton \& Buss, 2000), em que eles tendem a achar que qualquer mínimo sinal por parte das mulheres significa que elas estão interessadas sexualmente neles, como um simples olhar 
ou sorriso. Nesse caso, é menos custoso em termos de reprodução para o homem ele acreditar que há interesse e investir na relação com a mulher, do que o contrário, pois se a mulher realmente estivesse apresentando sinais de interesse e ele não reparasse, perderia uma chance de se reproduzir.

Portanto, a crítica que Haselton e colaboradores (2009) fazem é que normalmente os estudiosos não consideram o contexto ambiental em que o processamento de informações foi selecionado naturalmente, assim o julgamento do que é ou não uma decisão racional se torna pouco acurado. Os humanos existem e funcionam em um ambiente, e sob essa perspectiva, os vieses não são erros graves de uma mente irracional, mas são processamentos que normalmente levam soluções adequadas, quando verificadas as situações naturais em que ocorrem.

Em suma, à crítica de que o modelo do ser humano racional pressupõe que o ser humano funciona como uma máquina, pode ser acrescentada a crítica de Haselton e colaboradores (2009), de que o modelo também carece de uma perspectiva do ser humano como um animal, que evoluiu naturalmente em um contexto específico, para solucionar problemas típicos da espécie.

Portanto, ao modelo de racionalidade que originou o conceito dos vieses cognitivos várias críticas foram feitas, alguns exemplos são a da falta de consideração do papel das emoções e do processamento não consciente, e a da não contextualização do ser humano como um animal que existem em um ambiente.

As críticas, contudo, não necessariamente levam ao abandono do estudo dos vieses cognitivos. Ao contrário, acrescentam a ele novos modos de interpretação, que consideram outros fatores e de diferentes formas. Pode-se compreender os vieses, por exemplo, não como falhas da mente humana, e sim como descrições do funcionamento do nosso processamento mental. Estudá-los nos ajudam a entender esse funcionamento, e assim nos prover de mais conhecimento para desenvolver formas de modificá-lo, quando isso é desejado.

\subsection{Escolhas intertemporais: desconto do futuro}


Para sobreviver e se reproduzir, os animais têm que tomar decisões e a maioria delas envolve a dimensão do tempo. As denominadas escolhas intertemporais se referem a escolhas entre opções cujas conseqüências podem ocorrer em tempos diferentes, por exemplo, a decisão de fumar um cigarro ou não envolve duas conseqüências: a imediata, que é o prazer associado ao ato de fumar, e a posterior, que é a chance de aumento de doenças, como câncer de pulmão. Guardar dinheiro na poupança envolve o sacrifício de não gastá-lo agora, mas a possibilidade de gastá-lo no futuro.

É praticamente consenso entre as pesquisas que envolvem escolhas intertemporais que as recompensas futuras têm um valor menor para os humanos do que as presentes, fenômeno chamado de desconto do futuro - conceito estudado desde o início do século passado (uma revisão do tema pode ser encontrada em Frederick, Loewenstein, \& O’Donoghue, 2003). A recompensa futura é desvalorizada, descontada ou diminuída comparada a consequências imediatas, o que tem sido descrito como um viés cognitivo em favorecer o presente. Preferese o imediato ao posterior, quando se trata de consequências positivas, além disso, conseqüências futuras como dinheiro ou esforço a serem gastos no futuro são subestimadas (Akerlof, 1991; Soman, 1998). É como se fôssemos míopes: bons para enxergar o que está perto, mas ruins para enxergar o que está longe.

O desconto do futuro é considerado um viés quando esperar pelo futuro é considerado mais racional, de acordo com o modelo da maximização da utilidade. Ainda assim, os indivíduos têm demonstrado forte preferência pelo presente, não importando se a decisão que levaria a seus objetivos seria a de esperar pelo futuro. Essa compreensão do desconto do futuro como um viés será discutida posteriormente.

Muitos estudos que envolvem esse fenômeno, assim como o dos outros vieses, têm sido realizados na área da economia, envolvendo recompensas financeiras como forma de medida do desconto do futuro. A menor quantia de dinheiro que pode ser acessada imediatamente é muitas vezes preferida em vez de uma quantia maior, que só pode ser adquirida no futuro (Thaler, 1981). A menor quantia, porém imediata, possui um maior valor subjetivo (ou descontado) com relação à quantia mais alta, porém posterior.

A taxa em que futuras recompensas são desvalorizadas com relação ao tempo é chamada de taxa de desconto do futuro (future discounting) ou desconto temporal (temporal discounting), e apresentar uma alta taxa de desconto significa preferir o mais imediato ao posterior. Tanto em humanos quanto em outros animais, o modelo matemático de desconto 
hiperbólico tem sido o mais aceito para descrever a taxa de desconto do futuro (Kirby \& Marakovic, 1995) (Figura 1).

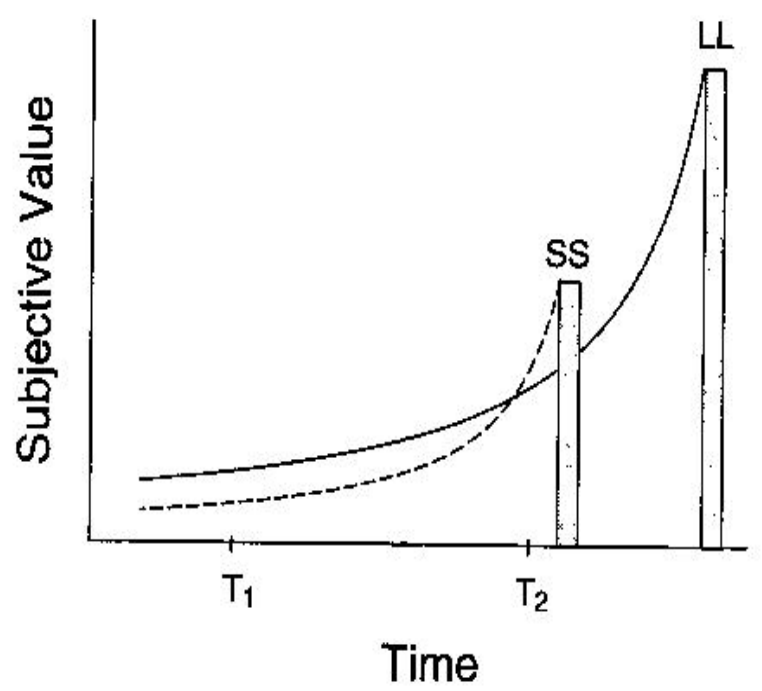

Figura 1: O valor subjetivo de uma recompensa menor e mais próxima e de uma maior e posterior em função do tempo. A altura das barras representa o tamanho real da recompensa (Green \& Myerson, 2004).

No desconto do futuro, ocorre o fenômeno conhecido por inversão de preferência (preference reversal), que pode ser visto na figura 1, no ponto de intersecção entre as curvas. A preferência pela recompensa menor e mais próxima ocorre até certo ponto, pois quando ela for recebida muito distante do presente, a recompensa maior e posterior começa a ser preferida.

Em estudo de Green, Fristoe e Myerson (1994), os participantes podiam optar entre receber $\$ 20,00$ imediatamente ou $\$ 50,00$ dali a um ano, e a maioria escolhia a primeira opção (desconto do futuro). Porém, quando os pesquisadores acrescentavam gradativamente mais tempo a essas opções (receber $\$ 20,00$ em dois meses ou $\$ 50,00$ em um ano; receber $\$ 20,00$ em três meses e \$50,00 em dois anos e assim por diante), os participantes começavam a inverter as escolhas, e preferir a recompensa maior e posterior. Os resultados são descritos na figura 2. 


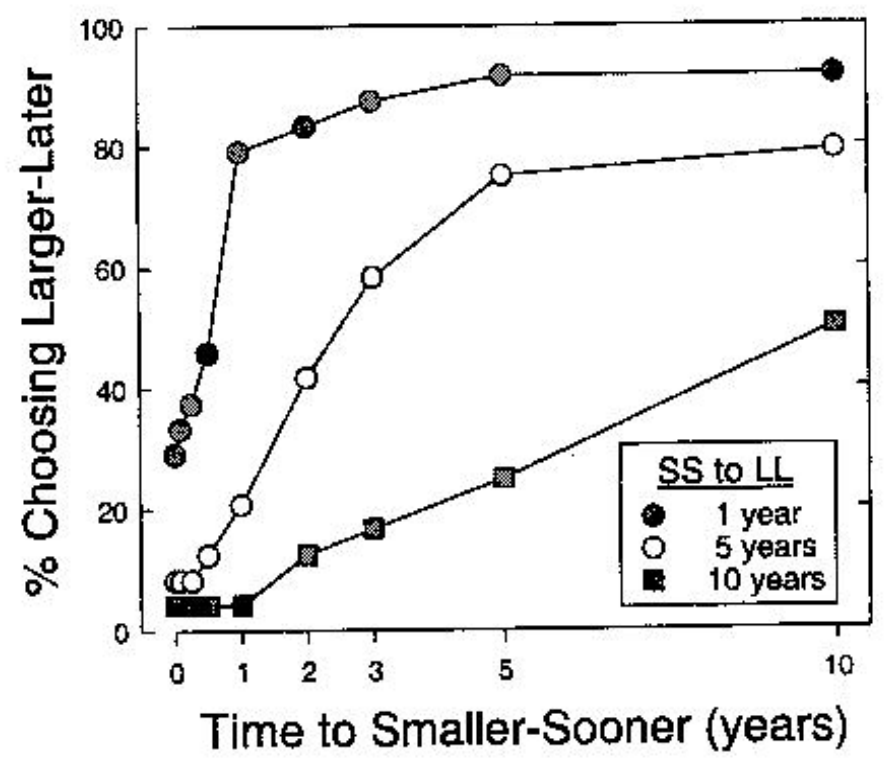

Figura 2: Porcentagem de participantes que escolhiam a recompensa maior e posterior, em função do tempo de espera até o recebimento da recompensa menor e mais próxima. As três curvas representam três condições experimentais: o tempo entre a recompensa menor e mais próxima e a maior e posterior ( 1 ano, 5 anos e 10 anos) (Green \&Myerson, 2004).

Essa inversão na preferência tem sido compreendida como uma diferença na velocidade de diminuição do valor subjetivo da recompensa. O valor subjetivo da recompensa maior e posterior diminuiria mais lentamente do que o valor subjetivo da recompensa menor e mais próxima conforme o recebimento da última se torna mais atrasado (Green \&Myerson, 2004).

Há vários modos de se acessar a denominada taxa de desconto do futuro dos indivíduos. Um deles é a tarefa de "escolha” (choice), em que se pergunta, por exemplo, se a pessoa prefere receber $\mathrm{R} \$ 200,00$ hoje ou $\mathrm{R} \$ 220,00$ amanhã. Nesse caso, os valores e a distância de atraso de recebimento da recompensa (nesse caso, um dia), já estão dados, e a tarefa do participante é optar entre uma delas. Outra forma é o matching, em que se deixa um espaço para o participante preencher: "Receber R\$ 370,00 em 17 semanas, é o mesmo que receber em 56 semanas”. Variações na forma de apresentação do problema de matching são possíveis. A primeira forma de medição tem como principal vantagem o fácil entendimento para o participante, e a segunda permite a sua livre expressão, proporcionando dados que não necessariamente eram esperados pelos pesquisadores. 
De acordo com Read, Frederick, Orsel e Rahman (2005), os processos psicológicos subjacentes às duas tarefas são diferentes (por exemplo, Tversky, Sattath \& Slovic, 1988; Frederick \& Shafir, 2004). Na tarefa de matching são necessários cálculos matemáticos, e o indivíduo pode acabar fazendo esses cálculos em cima de características que são pouco relevantes. Por exemplo, pode colocar um valor que seja múltiplo do primeiro valor oferecido em vez de pensar em características mais relevantes como aproximar o intervalo em valor de horas de trabalho (Frederick \& Shafir, 2004). Portanto, na tarefa de matching, habilidades matemáticas e de raciocínio envolvendo tempo e números são mais requeridas do que na tarefa de “escolha”, em que os dados já são apresentados, poupando recursos cognitivos do participante.

O método de "escolha” tem sido mais utilizado do que o de matching (Read \& Roelfsma, 2003), porém esses autores encontraram resultados semelhantes quanto à forma matemática da curva do desconto do futuro utilizando o método matching. Assim, mesmo que as tarefas cognitivas sejam diferentes, resultam em uma taxa de desconto do futuro semelhantes. Isso sugere que a taxa de desconto do futuro é relativamente estável, pois mesmo sendo acessada através de diferentes experimentos, que envolvem processamentos diferentes, ela se mantém, ou que os instrumentos, apesar de diferentes, acessam o mesmo fenômeno.

Os estudos já realizados apontam que o nível de desconto do futuro varia de acordo com fatores contextuais, culturais, individuais etc. Entender em que condições ocorre o desconto do futuro, como construto teórico assim definido, auxilia na compreensão do próprio conceito e dos relacionados a ele.

Quanto a fatores contextuais, há a recompensa, em que a maioria dos estudos envolve o dinheiro e poucos envolvem outras gratificações. Em um deles os benefícios futuros ocorriam na saúde, e houve resultados similares aos estudos com dinheiro (Chapman \& Sonnenberg, 2000). Assim como as pessoas preferem o dinheiro imediatamente, ainda que uma quantia maior possa ser adquirida no futuro, elas normalmente preferem prazeres e bemestar imediatos, como dormir e comer um doce, do que se exercitar e fazer dieta. As boas conseqüências para a saúde de se exercitar e se alimentar de modo equilibrado parecem ocorrer em um futuro muito distante. 
Com relação ao tamanho da recompensa, a taxa de desconto do futuro também varia, fenômeno denominado efeito da magnitude: quanto maior a recompensa, maior o desconto do futuro (Thaler, 1981; Green, Fristoe \& Myerson, 1994).

A respeito de diferenças culturais, Haipeng e colaboradores (Haipeng, Sharon \& Akshay, 2005) fizeram um estudo intercultural utilizando o cenário de uma compra online e as preferências na entrega do produto. Encontraram que os ocidentais descontam o futuro em um grau mais alto do que os orientais, e além disso, os ocidentais valorizam mais o consumo imediato dos bens do que os orientais.

Com relação às diferenças individuais, muitos fatores já foram pesquisados. Um deles é a diferença entre os gêneros, em que os experimentos diferem em seus resultados. Não foi encontrada diferença na taxa de desconto entre homens e mulheres em estudos de Kollins (2003), Reynolds, Karraker, Horn \& Richards (2003) e De Wit e colaboradores (2007). Alguns estudos encontraram que as mulheres descontam o futuro mais do que os homens (Logue \& Anderson, 2001; Reynolds et al., 2006). Em estudo de Kirby e Marakovic (1995) nos quais perguntaram se o indivíduo prefere receber uma quantia menor amanhã ou maior alguns dias depois, comparando idades e classes sociais semelhantes, os homens preferem a primeira opção. Em todos esses experimentos citados, foi utilizado o método de "escolha” para determinar a taxa de desconto do futuro. Em estudo de Zimbardo, Boyd e Keogh (1999), os homens apresentaram maior escore quanto à propensão a ter uma perspectiva de tempo voltada para o presente do que as mulheres.

Apesar dessas variações de resultados em função do gênero, em metanálise de Silverman (2003) as mulheres apresentam maior capacidade de adiar a gratificação, em que a diferença com relação aos homens foi pequena, mas significativa. O autor analisou 33 estudos, nas quais a recompensa era real e não hipotética. Quanto a essa dimensão, no estudo de Kirby e Marakovic (1995) em que os homens eram mais descontadores, tratava-se de um cenário hipotético. Quando realizaram um estudo semelhante envolvendo recompensas reais, não houve diferença entre os gêneros.

Embora haja divergências entre as pesquisas quanto a diferenças de gênero, a metanálise de Silverman (2003), assim como o estudo de Zimbardo, Boyd e Keogh (1999) fortalecem a noção de que as mulheres são menos imediatistas. Contudo, há indicações de que essa diferença possa não ser tão grande, e de que haja diferenças entre estudos em que a recompensa é real ou hipotética. 
É possível ainda que outras variáveis individuais interajam com o gênero, como possuir ou não filhos. Silverman (2003) cita o livro sobre maternidade de Rubenstein (1998), em que diz que as mulheres são mais aptas a fazer sacrifícios pelos filhos do que os homens. Além disso, Bjorklund e Kipp (1996) sugerem que em situações em que as necessidades de outras pessoas estão envolvidas, as mulheres são ainda mais capazes de adiar a gratificação. Também o estado civil poderia influenciar na taxa de desconto, talvez os solteiros invistam mais no presente e os casados no futuro, porém pesquisas precisam ser feitas. Não foram encontrados estudos que investigassem a diferença na taxa de desconto do futuro entre pessoas que têm filhos e as que não têm e as de diferentes estados civis, variáveis que poderiam acrescentar dados importantes à discussão das diferenças na capacidade de adiar a gratificação entre os gêneros.

Quanto à faixa etária, as crianças costumam ser bastante voltadas para o presente. A preferência por recompensas imediatas, ainda que a recompensa futura seja maior, parece surgir cedo. Mischel e colaboradores (1989) descreveram que crianças de quatro anos, tendo a possibilidade de escolher entre receber imediatamente um brinquedo não tão interessante, ou um mais interessante cinco minutos depois, escolhiam a primeira opção. Também preferiam comer um só marshmallow imediatamente, do que esperar alguns segundos e ficar com todo o pacote (Shoda et al., 1990).

Adolescentes demonstram uma orientação ao futuro mais fraca do que os adultos, porque aceitam mais uma recompensa menor imediatamente do que uma maior depois (Steinberg et al., 2009). Ao longo da vida, a taxa de desconto do futuro tende a decair (Green et al. 1999), ou seja, pessoas mais velhas dão mais peso para o futuro (Green, Fry \& Myerson, 1994). A figura abaixo representa a curva de desconto do futuro em diferentes grupos etários, representada através do valor subjetivo de uma recompensa e do atraso de tempo em que ela será recebida (Green et al., 1999): 


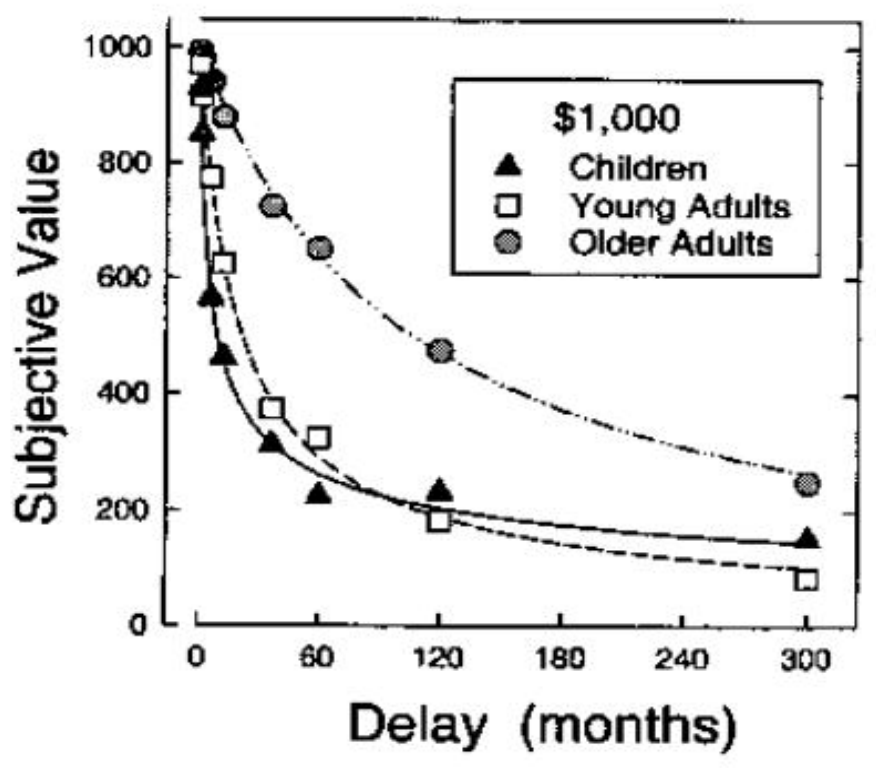

Figura 3: O valor subjetivo de $\$ 1.000$ em função do tempo de atraso de recebimento em meses para três diferentes grupos etários: crianças, adultos jovens e adultos mais velhos.

Com relação a abuso de substâncias, usuários de drogas tendem a apresentar maior desconto do futuro (Kirby et al. 1999), sendo bastante voltados para o presente (Zimbardo \& Boyd, 1999). Fumantes descontam mais o futuro do que não fumantes (Reynolds et al., 2004). Weller e colaboradores (2008) encontraram que mulheres obesas apresentam maior desconto do futuro do que mulheres não-obesas em cenários envolvendo dinheiro.

Em estudo de Stanovich e West (2008), os autores não encontraram uma correlação entre a presença de grande números de vieses cognitivos e capacidade cognitiva. Assim, pessoas mais inteligentes não necessariamente apresentam menos vieses em tarefas experimentais, assim como o oposto.

Características de personalidade também podem influenciar na taxa de desconto. Os extrovertidos e impulsivos descontam mais o futuro do que os introvertidos e pouco impulsivos (Green, Myerson \& Ostaszewski, 1999; Eysenck, Eysenck \& Barret, 1985). Contudo, não houve diferença entre pessoas que gostam de sensações fortes, como esportes radicais, e as que não gostam (Zuckerman, 1971).

Em estudo com idosos, Green e Myerson (1996) compararam os de renda alta e baixa quanto à taxa de desconto do futuro. As curvas dos dois grupos eram hipérboles, porém nos idosos com renda baixa ela era mais íngreme, sugerindo que descontam mais o futuro do que 
os de alta renda. Deve-se destacar a importância de se estudar fatores conjugados, como aqui foram a idade e a renda, pois as interações entre eles podem ser úteis para escolarecer a natureza subjacente do fenômeno do desconto do futuro.

Portanto, a partir dos estudos aqui citados há evidências de que tanto certas situações contextuais e mais maleáveis (como qual a recompensa e seu tamanho, distância temporal de recebimento) quanto características individuais e mais estáveis (como gênero, idade, personalidade) exercem influência na taxa de desconto do futuro.

\subsection{Desconto do futuro e risco}

As escolhas intertemporais costumam envolver outras dimensões contextuais além de qualidade, tamanho da recompensa e distância temporal, por exemplo envolvem também a probabilidade. Na área de decisão sob incerteza, Kahneman e Tversky (1979, Tversky \& Kahneman, 1979) desenvolveram a teoria do prospecto (prospect theory). Quando se deparam com escolhas que envolvem probabilidades, as pessoas superestimam probabilidades baixas, e subestimam probabilidades altas, e escolhem com base no valor do produto, e não de acordo com as reais probabilidades.

A teoria do prospecto não trata especificamente de escolhas intertemporais. Esperar pelo futuro normalmente envolve riscos como o da perda do recurso desejado ou da presença de mudanças que dificultem ou impossibilitem o acesso a ele. Assim, é possível que processos cognitivos subjacentes semelhantes ocorram na avaliação de riscos e probabilidade e nas escolhas intertemporais (Green \& Myerson, 1996).

Daly e Wilson (2005) atentam para o fato de que a preferência pelo recurso de acesso imediato pode ser adaptativa, pois quanto mais se adia o tempo de se aproveitar um benefício, maior é a probabilidade de perdê-lo. Para um chimpanzé, por exemplo, pode ser mais adaptativa a ânsia por consumir o recurso imediatamente (bananas, por exemplo), do que um mecanismo que o levasse a preferir guardar as bananas - em que haveria uma grande chance de outros membros do grupo acessar e roubar a comida.

O desconto do futuro é um comportamento comum no reino animal. Pombos famintos, que tenham a possibilidade de escolher entre receber comida imediatamente pelo tempo de 2 
segundos, ou receber comida 10 segundos após bicar no dispositivo, mas pelo tempo de 6 segundos, escolhem a primeira opção (Baron, 2008). Ratos com sede preferem uma quantidade menor de água imediatamente, do que uma maior quantidade depois (Richards, Mitchell, De Wit, \& Seiden, 1997).

Contudo, em alguns casos o adiamento do consumo dos bens é adaptativo. Os esquilos cinza (sciurus carolinensis) estocam castanhas, e se lembram da localização de cada uma delas no momento apropriado, meses depois no inverno (Jacobs \& Liman, 1991). Gerber, Reichman \& Roughgarden (2003) desenvolveram um modelo de previsão para mudanças no forrageamento, em que as estratégias dos animais de estocar ou consumir imediatamente o alimento variavam com relação à abundância de presas e à riqueza calórica dos alimentos. Portanto, uma série de variáveis influencia na decisão dos animais entre o imediato ou o posterior. Em algumas situações o imediato é mais adaptativo, principalmente pelo risco de perda do recurso, e em outras, o estoque é essencial para que o animal sobreviva posteriormente.

No caso humano, a preferência pelo tempo presente em relação ao futuro também nem sempre leva a conseqüências negativas, como o termo viés do desconto do futuro sugere. Por exemplo, levando-se em conta a teoria da utilidade econômica, em se tratando de dinheiro, adquirir a maior quantia de dinheiro poderia ser o mais racional. Portanto, receber R\$ 20,00 amanhã seria mais racional do que preferir receber $\mathrm{R}$ \$,00 hoje. O desconto do futuro é nesse contexto considerado um viés, ou algo negativo, como impulsividade, porque o maior benefício seria adquirir mais dinheiro, mesmo com tempo de espera, porque há uma alta chance da pessoa estar viva e em condições semelhantes no dia seguinte para receber a quantia.

Porém, preferir uma quantia menor de dinheiro imediatamente pode ser a escolha mais adequada em um país em crise, em que não há confiança no governo e nos bancos, que podem não cumprir a promessa de oferecer uma quantia maior no futuro, por exemplo. Nesse caso, as condições contextuais são conhecidas (o país está em crise), portanto ainda de acordo com a teoria da utilidade, a escolha da menor quantia imediatamente seria racional, dadas as condições econômicas. Assim, do mesmo modo que os animais que estocam comida mudam suas decisões de consumo imediato ou estoque de acordo com as condições ambientais, o ser humano pode estar mais voltado para o presente ou para o futuro de acordo com o contexto, e a decisão de privilegiar o presente pode ser racional, dadas as condições. 
Mais difícil, entretanto, é avaliar cenários incertos. A economia do país pode estar estável agora, mas há uma chance de se tornar ruim nos próximos meses. A inflação pode fazer com que receber $\mathrm{R} \$ 10,00$ hoje deixe o indivíduo com mais dinheiro do que se ele receber $\mathrm{R} \$ 50,00$ daqui a uma semana. O indivíduo pode morrer no período de espera para receber o dinheiro, o que faria com que receber $\mathrm{R} \$ 10,00$ hoje o deixasse com mais dinheiro do que receber R\$ 100,00 daqui a um mês. Ou o contrário, hoje o indivíduo é pobre, e daqui a dois meses pode ganhar na loteria e ficar milionário, então receber $\mathrm{R} \$ 10,00$ hoje vale mais do que receber $\mathrm{R} \$ 1.000$ daqui a dois meses.

Portanto, esperar para usufruir de um recurso no futuro envolve o risco de perdê-lo, ou de ele não valer tanto, pois a situação pode mudar e o recurso pode não estar mais disponível ou ser menos valioso. Várias das escolhas humanas envolvem o risco, e tanto humanos quanto outros animais parecem ser avessos a ele, ou seja, tendem a evitar situações de risco (Chen, Kalra \& Sun 2009; Kacelnik \& Bateson 1996; Simonsohn, 2009; Weber, Shafir \& Blais, 2004).

Em situações de risco em geral, as mulheres parecem ser mais avessas ao risco do que os homens. Em experimentos que envolviam a possibilidade de arriscar em situações de negócios, com aplicações de menor rendimento e mais garantidas ou de maior rendimento, mas menos garantidas (como poupança versus investimento em ações), as mulheres apresentaram maior aversão ao risco do que os homens (Hudgens \& Fatkin, 1985; Johnson \& Powell, 1994; Sexton \& Bowman-Upton, 1990; Levin et al., 1988; Powell \& Ansic, 1997).

As mulheres também apresentam menor chance de se envolver em comportamentos de risco como uso de drogas e atividades criminosas (Daly \& Wilson, 1988), assim como são mais avessas ao risco em jogos de azar (Levin, Snyder, Chapman, 1988; Hartog, Ferrer-iCarbonell, Jonker, 2002). Os homens buscam mais sensações fortes como esportes radicais do que as mulheres (Zuckerman, Eysenck \& Eysenck, 1978).

A mensuração do risco, ou seja, a medida do quanto o indivíduo é propenso a se arriscar em situações de alto risco explícito, é chamada de desconto probabilístico (probability discounting). As relações entre o desconto do futuro e aquelas do desconto probabilístico são discutidas em revisão de Green e Myerson (2004), que afirmam que ambas as formas de desconto são descritas pela mesma forma de função matemática (Figura 4). 
Do mesmo modo que o desconto do futuro envolve muitas vezes a escolha dentre uma recompensa menor e mais próxima a uma maior e mais distante, no desconto probabilístico a escolha é entre uma recompensa menor e com menos risco e uma maior, com mais risco. Quando duas recompensas estão longe no futuro, o indivíduo tende a escolher a maior (reversão na preferência), assim como quando as chances de receber as duas recompensas são baixas (alto risco), o indivíduo tende a escolher a maior.

Assim, quando duas recompensas têm risco baixo, mas não idêntico (por exemplo, risco de perda de $0,5 \%$ e de $0,7 \%$ ), o indivíduo tende a preferir a recompensa maior, mesmo que ela estiver associada a um ligeiro aumento de risco (no caso, de 0,7\%), e quando as probabilidades de risco aumentam proporcionalmente (por exemplo, se tornando 1,5\% e 2,1\%), tendem a preferir a menor e com menos risco (a de 1,5\%) (Rachlin, Castrogiovanni, \& Cross, 1987). Desse modo, ocorre uma reversão da preferência quando a taxa de risco muda, similar à reversão na preferência quando o tempo muda no desconto do futuro, em que o risco baixo seria o tempo distante, e o risco alto, o tempo mais próximo.

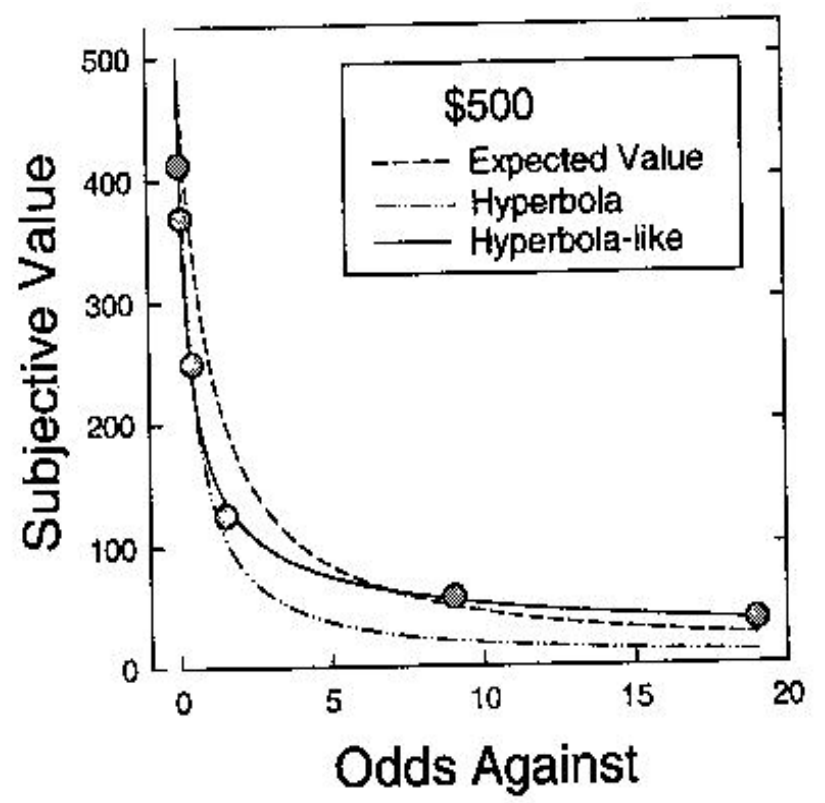

Figura 4: O valor subjetivo de $\$ 500$ como função das chances contra seu recebimento. A curva semelhante a uma hipérbole se adequa aos resultados, sendo parecida com a curva do desconto do futuro. Dados do Experimento 1 de Green, Myerson \& Ostaszewski (1999). 
Para acessar o desconto probabilístico, uma das formas é uma medida de aversão ao risco, através de tarefas de escolha financeira semelhantes às do desconto do futuro. $\mathrm{O}$ indivíduo pode optar entre receber $\$ 10$ com certeza ou ter 50\% de chance de ganhar $\$ 20$ ou receber $\$ 100$ com certeza e ter a chance de ganhar \$500 e assim por diante. Estudos demonstram que pessoas que têm aversão ao risco com relação a pequenas quantias de dinheiro, têm ainda mais aversão conforme a quantidade de dinheiro em jogo aumenta (Green, Myerson \& Ostaszewski, 1999).

Para Green e Myerson (2004) a inabilidade para adiar a gratificação (alta taxa de desconto do futuro) está relacionada com a tendência a assumir riscos e apostar em jogos de azar (baixa aversão ao risco). No mesmo sentido, menor aversão ao risco financeiro e a alta taxa de desconto do futuro estavam correlacionadas em pesquisa de Petry \& Casarella (1999). Contudo, em pesquisa de Guth e Sonsino (2001), participantes que apresentaram alto grau de aversão ao risco também eram mais descontadores do futuro. Portanto, a relação entre esses dois fenômenos não é tão esclarecida. Para esses autores (Anderhub, Guth, Gneezy \& Sonsino, 2001), o tempo de espera para receber a recompensa significa risco, portanto aqueles que são mais avessos ao risco tendem a preferir receber o prêmio imediatamente. Assim, haveria dois aspectos no consumo imediato de um recurso: o prazer de usufruí-lo agora e o risco praticamente inexistente de não ter acesso a ele. Entretanto, as pesquisas apresentam dados conflitantes sobre a relação entre desconto do futuro e aversão ao risco.

Alguns autores questionam se o desconto probabilístico e o desconto do futuro são apenas um processo geral de desconto (Green \& Myerson, 2004), ou se algum dos dois é mais fundamental e o outro é consequência. Fehr (2002) argumenta que o processo fundamental é o desconto probabilístico, e que o desconto do futuro surge porque intervalos maiores aumentam a probabilidade de perda de acesso ao recurso, visão comum em estudos sobre forrageamento de outros animais (Houston, Kacelnik \& McNamara, 1982). Se são o mesmo processo, variáveis que afetam um deles deveriam afetar o outro de forma semelhante, o que não tem sido encontrado em pesquisas até o momento (Green \& Myerson, 2004). Para Green e Myerson (2004) ambos deveriam ser mais estudadas juntos, pois grande parte das decisões que tomamos envolvendo a dimensão temporal também envolvem a dimensão do risco, e mais dados sobre a relação entre os dois poderiam ser discutidos. 
As mais diversas pesquisas têm encontrado a presença do fenômeno do desconto do futuro, porém há menos consenso na discussão sobre os seus antecedentes psicológicos (Soman et al, 2005). Uma das visões mais conhecidas é a aproximação com o conceito da impulsividade, de Ainslie (1975). Para o autor, somos impulsivos quando escolhemos a recompensa menor e imediata a uma maior e posterior.

Alguns autores trabalham com a idéia de disputa entre diferentes selves (Parfit, 1971, 1987; Schelling, 1984). Do mesmo modo que em um grupo social um indivíduo pode brigar com outro por recursos (por exemplo, dinheiro), nas escolhas intertemporais seria como se o self do presente estivesse brigando com o self do futuro (Baron, 2008). Assim, teríamos um viés em relação ao nosso self do presente, porque o self do futuro está distante. É como se a satisfação que se tem ao consumir um item hoje, por exemplo, fosse maior do que a satisfação de consumi-lo no futuro, simplesmente porque o self do futuro é quase outra pessoa, com quem temos uma ligação mais fraca do que com o self do presente.

Essa facilidade com que privilegiamos o self do presente faz com que desenvolvamos mecanismos psicológicos de autocontrole (Ainslie, 1992; Strotz, 1955; Thaler, 1981). No exemplo anterior das conseqüências na área da saúde, as pessoas costumam desenvolver algumas formas de autocontrole para manter a saúde, por exemplo, se matricular em uma academia e ir porque o mês já foi pago, passar longe das docerias, possuir apenas vegetais na geladeira. Quanto a dinheiro, pode-se deixar o cartão de crédito em casa, sair com poucas notas, pedir ao banco para colocar uma quantia do salário na poupança automaticamente etc. São formas de considerar o self do futuro, garantindo para ele boas condições de vida, como ter saúde e dinheiro.

Baron (2008) questiona se deveríamos realmente considerar o self do futuro tanto quanto consideramos o do presente, ou seja, se a noção de desconto do futuro como um viés realmente se aplica. O autor cita Parfit (1987), que considera que nossa preocupação com nosso self do futuro deveria ser a mesma que temos com uma pessoa próxima a nós, como um parente. Afinal, o self do futuro ainda não é a pessoa do agora, mas será um dia alguém muito relacionado com o que somos hoje. Portanto, se nos preocupamos com nossas mães e pais, que são pessoas bastante próximas a nós, mas não são nós, deveríamos nos preocupar com nós mesmos no futuro. Essa preocupação deveria existir, porém não deveria ser tão alta quanto a preocupação com o self do presente. 
Para Baron (2008) deveríamos planejar nossas vidas como um todo composto de partes, e o presente seria apenas uma delas. Viver apenas pensando no presente imediato talvez não beneficie todas as outras partes, daí porque o autor concorda que existe um viés para o presente e que deveríamos amenizá-lo através do autocontrole. Aliás, o autor frisa que é justamente porque sabemos que o futuro é importante que quando percebemos que o negligenciamos desenvolvemos várias formas de autocontrole.

Outros autores explicam o desconto do futuro com o auxílio de conceitos cognitivos de representação de presente e futuro (Malkoc \& Zauberman, 2006; Trope \& Liberman, 2003), outros com diferenças individuais na orientação temporal (Carstensen, Isaacowitz, \& Charles, 1999; Zimbardo \& Boyd, 1999). Essas visões não são incompatíveis com as anteriores, contudo o foco dos autores é diferente.

Em revisão da área de escolhas intertemporais, Soman e colaboradores (2005) acreditam que entender melhor a percepção de tempo é um fator crítico para se entender as escolhas intertemporais. Para eles, haveria duas questões de interesse: o tempo de espera da recompensa (chamado de "atraso”) deve ser medido pelo tempo objetivo (o do relógio) ou pelo tempo percebido subjetivamente? E se é o tempo percebido, trata-se do tempo percebido no momento? Ainda poderia ser acrescentado, o tempo percebido como uma medida mais estável da personalidade, uma orientação temporal (como em Zimbardo \& Boyd, 1999)?

Zauberman, Kim, Malkoc e Bettman (2009) realizaram alguns estudos referentes à primeira questão, e afirmam que nas pesquisas feitas com desconto do futuro o tempo era medido objetivamente, por exemplo, um atraso de um mês era contado como realmente um mês. Sugerem que o foco deveria ser em como as pessoas percebem o atraso da recompensa, ou seja, em como elas mapeiam o tempo objetivo através de percepções subjetivas de tempo, em que um mês objetivo pode não corresponder a um mês subjetivo.

Em um dos seus estudos, aos participantes era mostrado um cenário hipotético em que eles ganhavam um vale-presente de $\$ 75,00$. Era então perguntado quanto que esse valepresente deveria valer para que eles esperassem um mês (ou um ano, ou três anos, nos outros grupos de participantes) para usá-lo, em vez de usar imediatamente. Em seguida, deveriam marcar em uma régua de 180 milímetros em que na ponta esquerda estava escrito "muito curto” e na ponta direita, “muito longo” quão distante consideravam hoje em relação ao tempo que deveriam esperar para usar o vale-presente. A média em milímetros para três meses foi de 105.85, para um ano foi de 131.25, e para três anos, 140. Estatisticamente, não houve 
diferença entre as condições de um ano e de três anos. Os resultados mostraram que a estimativa subjetiva do futuro muda menos do que o tempo real, em que a diferença entre um ano e três anos é muito pequena, demonstrando uma insensibilidade ao horizonte temporal mais distante.

Além disso, quanto mais longe era percebida a distância da espera, maior a taxa de desconto do futuro. Assim, concluímos que quanto mais longe subjetivamente está a data de entrega de uma recompensa, mais difícil é aceitar a espera, e preferimos algo imediato, mesmo que menor. Novamente, isso pode ser relacionado ao conceito de self do futuro: quanto mais distante sentimos que o self do futuro está, mais difícil é sentirmos uma ligação com ele. Ou ainda com o risco, pois quanto mais distante sentimos que está o recurso, maior achamos que é a probabilidade de o perdermos.

Para os autores, a percepção de tempo humana não é acurada, e seus estudos dão suporte à idéia de que o tempo subjetivo é contraído em relação ao tempo objetivo. Um tempo de espera de três anos, subjetivamente, é próximo ao tempo de espera de um ano. Os autores sugerem que chamar a atenção para a dimensão do tempo pode contribuir para um melhor mapeamento temporal, que por sua vez poderá facilitar a compreensão do desconto do futuro.

Outro aspecto do tempo subjetivo foi destacado por Read e colaboradores (2005), que atestam que os pesquisadores da escolha intertemporal não se preocupam se a forma como o atraso é descrito interfere nos resultados. Nos experimentos em que a conseqüência de uma escolha ocorrerá no futuro, os pesquisadores podem escrever esse tempo de várias formas, em dias, meses, data de calendário (por exemplo, "Você prefere receber $\mathrm{R} \$ 50,00$ hoje ou R \$110,00 no dia 16 de maio de 2011?”, ou “Você prefere receber $\mathrm{R} \$ 50,00$ hoje ou $\mathrm{R} \$ 110,00$ daqui a dois meses?”). Em seu artigo, Read e colaboradores (2005) pesquisaram o efeito de apresentar o tempo da conseqüência em forma de data de calendário ou unidades de atraso, que se refere ao tempo em que a recompensa será dada, contando a partir de hoje até a data futura (por exemplo, em dias ou meses).

Demonstraram que o tempo é tratado de modo diferente quando mostrado como data e como atraso, já que ao visualizar a data, os participantes demonstraram menor desconto do futuro. Os autores descreveram o date/delay effect, ou efeito data/atraso, em que o futuro é mais descontado quando é apresentado em forma de atraso (6 meses) do que em forma de data (16 de setembro). 
Zauberman e colaboradores (2009) especulam que o date/delay effect se relaciona com a percepção subjetiva, em que a data seria percebida como mais próxima do tempo presente, ou seja, mais contraída do que o atraso. Convidaram 28 estudantes a estimar a duração de tempo em uma régua de 180 milímetros, em que para metade deles o intervalo era descrito como atraso (por exemplo, uma semana) e para a outra metade, como data de calendário (24 de outubro). Os estudantes estimaram como mais longo o intervalo quando mostrado como atraso (média de $65.36 \mathrm{~mm}$ ) do que como data de calendário (38.79 mm).

Não foi encontrado um estudo utilizando ainda outra forma de descrição da data, por exemplo, utilizando uma situação comemorativa ou um feriado (“seu aniversário” ou "feriado do dia do trabalho"). Pode-se conjecturar que o efeito seria mais semelhante ao da data (16 de setembro) do que do atraso (6 meses), porque a forma de feriado é pontual, não representando um intervalo de tempo corrido, como no atraso.

Ainda se pode questionar o efeito de utilizar números em forma escrita (três) ou em numeral arábico (3). Em alguns modelos de processamento de informações numéricas, é proposto que os números arábicos e verbais têm uma rota direta, sem passar por uma representação de quantidade intermediária (Dehaene \& Cohen, 1995). Assim, o processamento de ambas as formas de apresentação de números seria semelhante.

A estreita relação entre o desconto do futuro e a percepção de tempo merece mais investigação. É possível que, como os autores citados apontaram, grande parte dos estudos na área de desconto temporal tenha considerado o tempo como uma medida objetiva, que seria compreendida igualmente por todos. O questionamento desse pressuposto, através da melhor compreensão de como os humanos entendem o tempo, pode levar a importantes elucidações e mudanças na compreensão do desconto do futuro.

\subsection{Percepção de tempo}

Não é recente a noção de que o tempo subjetivo é diferente do tempo objetivo, aquele contado através dos relógios. Alguns autores se dedicaram a estudar o fenômeno da percepção de tempo sob variados pontos de vista teóricos e com variados objetos de estudos. William James, considerado o pai da psicologia americana, considerava que a perspectiva de tempo é o conhecimento do passado e do futuro, que está misturado com o que consideramos o presente 
(Zimbardo \& Boyd, 2008). Para Paul Fraisse, o pai do estudo psicológico do tempo, nossas ações no presente não dependem somente do que está acontecendo no momento, mas também do que experienciamos no passado e de nossas expectativas futuras (Zimbardo \& Boyd, 2008).

O tempo parece ser uma dimensão mais maleável do que outras, porque é mais facilmente manipulável experimentalmente: pode-se tanto torná-lo um detalhe sem importância, quanto realçá-lo, colocando-o em destaque. Em pesquisas que envolvem dinheiro, por exemplo, ele sempre tem importância e não é ignorado, porém, “o tempo pode ficar tanto nos bastidores quanto ser o elemento principal” (Ebert \& Prelec, 2007).

Além disso, as pessoas têm dificuldade em compreender o tempo como uma dimensão independente, e tendem a vinculá-lo a acontecimentos e sentimentos. Têm também dificuldade em estimar a duração de um evento (Fredrickson \& Kahneman 1993), e dificuldade em avaliar a duração de algo em isolamento, sem contexto (Ariely \& Loewenstein 2000; Hsee, 2000). Porém a maior parte das pesquisas foi feita considerando o tempo passado, e não o futuro (Zauberman et al., 2009).

Há diferenças culturais na percepção do tempo. Graham (1981) definiu três tipos de orientação temporal, a linear-separable, circular traditional e procedural-traditional. Os europeus apresentariam a primeira, em que o tempo é visto como um contínuo do passado ao presente e ao futuro, e ao tempo é atribuído um valor monetário, “tempo é dinheiro”, pois sabe-se que tempo e dinheiro têm uma relação próxima. Na segunda orientação, que seria típica de algumas culturas latinas, o tempo é visto como cíclico, e a orientação é mais voltada para o presente. Na última orientação, mais comum aos índios americanos nativos, o tempo é menos importante, e não há uma correlação entre tempo e dinheiro (ou algo de valor).

Hofstede e Bond (1988) trabalharam com as diferenças na orientação temporal entre ocidente e oriente, e encontraram que as culturas asiáticas valorizam mais o futuro do que o presente quando comparadas às culturas ocidentais.

Ainda na linha de comparações interculturais, Robert Levine, autor de vários estudos mais recentes na área, através das lentes da psicologia social pesquisou a atitude em relação ao tempo, que ele denominou "marcha da vida” (no original, pace of life - Levine \& Norenzayan, 1999), que se relaciona com o comportamento social dos membros de certa comunidade. Através de medidas como acurácia dos relógios, velocidade de caminhada, 
velocidade de transações financeiras, e outras, ele calculou a "marcha da vida” em várias cidades e países. Em seus resultados, por exemplo, o Japão demonstrou ser uma sociedade com alto índice, o que significa um ritmo rápido, e o México, um baixo índice, demonstrando um ritmo mais lento.

Levine influenciou muitos outros pesquisadores, dentre eles Philip Zimbardo e John Boyd. Esses autores dedicaram muitas pesquisas a entender a percepção de tempo, porém seu foco, diferentemente de Levine, foi no indivíduo, em como aspectos do ambiente são internalizados, estando presentes em seus pensamentos, comportamentos e sentimentos. Essa atitude com relação ao tempo, que eles chamaram de perspectiva de tempo (time perspective), seriam aprendidas. A comunidade, a cultura, a família, a religião, as limitações socioeconômicas, geográficas, o momento político etc., podem influenciar a perspectiva temporal de um indivíduo.

As perspectivas de tempo se referem às crenças, atitudes, valores e comportamentos relacionados ao tempo, e seriam predominantemente quanto ao futuro, presente ou passado. Zimbardo e Boyd (1999) desenvolveram um questionário que mede essa perspectiva, o Zimbardo Time Perspective Inventory (ZTPI). As cinco dimensões medidas (passadonegativo, presente-hedonístico, futuro, passado-positivo, e presente-fatalístico) refletem atitudes, experiências pessoais e sociais frente a essas dimensões temporais. Trata-se de uma medida mais relacionada à personalidade, a características mais estáveis das pessoas, podendo ser usada para pesquisas sobre diferenças individuais. O ZTPI foi adaptado e validado no Brasil em estudo de Milfont, Andrade, Belo e Pessoa (2008), e consiste em várias sentenças afirmativas envolvendo o tempo, em que o indivíduo deve responder o quanto cada uma tem a ver com ele.

Pessoas voltadas para o passado poderiam ter tanto muitas memórias positivas, como de rituais familiares, situações boas da infância, objetivos atingidos, sucesso, quanto memórias negativas, como aspectos ruins da infância, fracassos, sofrimentos. Tanto em um caso quanto no outro, se tornam quadros mentais de referência. Essas pessoas querem garantir que o presente e o futuro não sejam piores do que o passado.

A dimensão do futuro, como descrita por Zimbardo e Boyd (1999), se refere a quanto o indivíduo prefere o planejamento, a quanto não gosta de estar atrasado ou descumprir prazos e metas e a quanto consegue adiar o prazer para conseguir cumprir suas responsabilidades. Portanto, trata-se de uma dimensão bastante relacionada à adequação social, à 
responsabilidade em geral, e à capacidade de administrar o tempo para que obrigações sejam cumpridas. Por exemplo, algumas das questões do questionário referentes à dimensão do futuro são: “Cumprir os prazos para amanhã e fazer outros trabalhos necessários vêm antes da diversão noturna”; “Quando quero alcançar algo, estabeleço objetivos e considero formas específicas para atingi-los”.

De acordo com pesquisas realizadas por esses autores, pessoas orientadas para o futuro tendem a ser mais bem-sucedidas profissionalmente, se alimentar melhor e se exercitar mais, ir mais ao médico, não usar drogas, não fumar, ter menos filhos, gastar menos tempo em lazer e em férias. Alguns fatores que contribuem para que alguém desenvolva uma perspectiva voltada para o futuro são viver em uma zona climática temperada, ter educação formal, viver em uma família e nação estáveis, ter um trabalho e ter modelos de pessoas orientadas para o futuro. Como tendem a ser pessoas com mais educação formal, normalmente conseguem bons empregos, e tendem a economizar dinheiro, e gastar menos em situações sociais, portanto costumam ter mais dinheiro. Poderíamos esperar que uma pessoa orientada para o futuro, nos termos descritos por Zimbardo e Boyd (1999), tenderia a descontar menos o futuro. Já que consegue adiar o prazer para cumprir objetivos, conseguiria adiar o prazer do presente para alcançar algo maior no futuro.

Já a orientação para o presente, como desenvolvida pelos autores, se refere a preferir aproveitar o momento a pensar no amanhã, a viver cada dia como se fosse o último, a não fazer planos e a ter dificuldade de visualizar o tempo que demandará para cumprir uma tarefa. Algumas das sentenças do questionário referentes à dimensão do presente são: “Sempre existirá tempo para colocar meu trabalho em dia”; “Tento viver minha vida tão intensamente quanto possível, um dia de cada vez”; “Aceito cada dia como ele é, ao invés de tentar planejálo”.

Os indivíduos orientados para o presente tendem a ajudar mais os outros, se engajar em comportamentos sexuais de risco, em jogos de azar, uso de drogas e álcool. Pessoas vivendo em países com economia instável tendem a apresentar essa perspectiva de tempo, pois o presente é certo, já o futuro não. Não se pode confiar no governo e nas instituições, portanto o foco no futuro diminui, as decisões têm que ser tomadas aqui e agora. Quanto menos educação formal (ocorrida em escolas, de forma intencional e com objetivos definidos) o indivíduo tem, maior a chance de ele desenvolver uma perspectiva de tempo voltada para o presente. E quanto às classes sociais, quanto mais baixas, também maior a orientação para o 
presente, já que uma orientação para o futuro é necessária para se pensar em guardar dinheiro, e planejar a vida financeira. O uso de drogas também pode levar a pessoa, pelo menos momentaneamente, a ficar orientada para o presente. A pessoa orientada para o presente costuma ser hedonista, vivendo a vida intensamente, se engajando em diversas atividades, como esportes. Fazem amigos e parceiros amorosos facilmente. Desse modo, poderíamos prever que um indivíduo voltado para o presente descontaria mais o futuro, ou seja, valorizaria o momento presente e pensaria pouco no futuro.

A percepção do tempo, portanto, pode ser estudada sob variados pontos de vista, como um constructo mais social, ou mais individual, mais estável na personalidade, ou mais instável e sujeito a condições do momento.

\subsection{Desconto do futuro e percepção de tempo}

A tomada de decisão e o fenômeno do desconto do futuro, relacionados às escolhas intertemporais, têm sido bastante pesquisados. Estudar e compreender as escolhas intertemporais tem grande aplicação prática, pois todos fazem escolhas que envolvem a dimensão do tempo cotidianamente, e as conseqüências dessas decisões afetam tanto o indivíduo, quanto sua família, outras pessoas a sua volta, empresas, governo e a sociedade.

A percepção de tempo também tem sido largamente estudada, sob as mais variadas linhas teóricas e metodologias, porém foi pouco relacionada ao fenômeno de desconto do futuro. Nesse trabalho focamos nas perspectivas de tempo acrescentadas por Read e colaboradores (2005) e Zauberman e colaboradores (2009), com relação à falta de acurácia humana ao horizonte do futuro, e em Zimbardo e Boyd (1999), como uma perspectiva de tempo, uma dimensão mais estável da personalidade do indivíduo. Essas perspectivas focam mais no indivíduo, e tratam também da dimensão do futuro, o que era essencial no estudo do desconto do futuro. Read e colaboradores (2005) e Zauberman e colaboradores (2009) já iniciaram o estudo da percepção de tempo dentro do conceito de desconto do futuro, e nesse trabalho reproduzimos em parte seus experimentos, para testar em uma amostra brasileira. Quanto à Zimbardo e Boyd (1999), até o início da coleta de dados não foi encontrado um trabalho que unisse os conceitos desenvolvidos por esses autores e o desconto do futuro. 
Assim, consideramos que essa teoria acrescentaria noções e dados importantes aos já existentes no campo do desconto do futuro.

Nesse estudo, unimos essas duas grandes áreas de pesquisa, por considerar que a percepção de tempo teria muito a elucidar do fenômeno de desconto do futuro. As escolhas intertemporais envolvem a dimensão temporal, e sendo a percepção de tempo humana um fenômeno subjetivo, esperamos que haja uma relação entre o desconto do futuro e o modo como percebemos o tempo.

As escolhas intertemporais também costumam envolver riscos, por isso adicionamos um instrumento para acessar a aversão ao risco, como forma de enriquecer os dados e as discussões subseqüentes acerca da relação entre desconto do futuro e aversão ao risco, e a relação entre eles e a percepção de tempo.

O objetivo geral foi investigar o fenômeno do desconto do futuro e sua relação com o modo com que percebemos o tempo subjetivamente. Acessamos a taxa de desconto do futuro (“Cenário do cupom”), utilizando a manipulação da forma de apresentação do tempo em quatro condições (“noventa dias”, “três meses”, “data” e “feriado”). Além disso, medimos a aversão ao risco (“Aversão ao risco”), a percepção subjetiva de distância de certo intervalo de tempo (“Distância da data”) e a orientação temporal para o presente e para o futuro (“ZTPI”).

Com isso, acrescentamos dados de uma amostra brasileira e realizamos associações inéditas entre percepção de tempo e desconto do futuro. Esperamos ter realizado contribuições para a área de estudos do desconto do futuro, com dados e reflexões sobre o papel que a percepção subjetiva de tempo exerce, assim como a aversão ao risco.

\subsection{Hipóteses}

Com base nos trabalhos citados, temos algumas hipóteses para os resultados dessa pesquisa.

Com relação ao gênero: 
a) As mulheres apresentarão menor taxa de desconto do futuro, maior aversão ao risco, menor distância subjetiva da data (por causa da menor taxa de desconto do futuro) e serão mais voltadas para o futuro.

Com relação à idade:

b) Os participantes mais jovens apresentarão maior taxa de desconto do futuro do que os mais velhos, maior distância subjetiva da data (por causa da maior taxa de desconto do futuro), menor aversão ao risco, e serão mais voltados para o presente.

Quanto ao instrumento “distância da data”:

c) O grupo experimental "data” e "feriado" apresentarão menor taxa de desconto do futuro do que os grupos “noventa dias" e "três meses”, devido ao date/delay effect.

Quanto às correlações entre os instrumentos - desconto do futuro, aversão ao risco, a distância subjetiva da data e a orientação temporal:

d) Os participantes com maior desconto do futuro apresentarão menor aversão ao risco, verão o futuro como mais longe subjetivamente, e serão mais voltados para o tempo presente.

e) Os participantes com menor desconto do futuro apresentarão maior aversão ao risco, verão o futuro como mais perto subjetivamente, e serão mais voltados para o tempo futuro. 


\section{MATERIAL E MÉTODOS}

\subsection{Participantes}

Participaram da pesquisa 208 brasileiros, com idades entre 18 e 71 anos, que tiveram acesso ao link da pesquisa e aceitaram o termo de consentimento antes de realizá-la.

\section{2 Material}

O material (ANEXO B) consistiu de um questionário de dados demográficos com itens sobre gênero, idade, nível de escolaridade, situação amorosa, se tem filhos e quantos, e de um conjunto de quatro instrumentos. A aprovação da aplicação do material foi obtida junto ao Comitê de Ética de Medicina da Universidade de São Paulo, em 25 de maio de 2011, pelo protocolo de pesquisa número 144/11 (ANEXO A).

O primeiro instrumento, “Cenário do cupom” visava a medir a taxa de desconto do futuro do participante, uma tarefa comumente usada como medida de preferência temporal (Thaler, 1981; Zauberman et al., 2009). Optou-se pela forma de matching e não de "escolha” para se medir a taxa de desconto do futuro, como feito no estudo de Zauberman e colaboradores (2009). Isso para permitir melhor comparação com o estudo desses autores, e porque há mais liberdade para o participante, permitindo a exploração de mais processos psicológicos subjacentes do que no caso de um questionário com opções fechadas, como no de "escolha".

O “Cenário do cupom” é um cenário hipotético em que o participante ganha um cupom de vale-compras. No original (Zauberman et al., 2009), a tarefa é explicada da seguinte forma:

Participants first were presented with a scenario asking them to imagine receiving a gift certificate worth $\$ 75$. They were then told that the gift certificate was valid today and were asked to indicate how much they would need to be paid to wait for 1 month before using the gift certificate. (p. 546). 
Na tradução e adaptação ao português e à atual pesquisa, foi escolhido o valor de RS 100,00, por ser considerada uma quantia moderada, nem muito baixa, nem muito alta, de modo a ser verossímil. Foi então perguntado qual o valor mínimo que o participante teria que ganhar para esperar um determinado intervalo de tempo para receber o vale. Em nosso questionário, após um pré-teste, em que dois sujeitos leram e disseram o que entenderam da pergunta, a forma final do cenário ficou da seguinte forma: "Suponha que você ganhou um cupom de vale compras no valor de 100,00 reais. O cupom é válido a partir de hoje. Qual teria que ser o valor mínimo desse cupom para que você esperasse noventa dias para poder usálo?”.

O intervalo sempre era de três meses, para todos os participantes, porém para cada um dos quatro grupos experimentais, o intervalo foi apresentado de uma forma diferente, para verificar a presença do date/delay effect (Read et al., 2005). Para o grupo 1 foi apresentado como “noventa dias”, para o grupo 2 como "três meses”, para o grupo 3 (“data”) como uma data escrita por extenso que equivalia ao tempo de aproximadamente três meses em relação a data que o participante estava respondendo (por exemplo, “oito de setembro" e "dez de outubro"), e para o grupo 4 (“feriado”), na forma de um feriado que equivalia ao tempo aproximado de três meses (“dia da pátria” e “dia das crianças”) . Foi acrescentada uma forma de escrita além das sugeridas por Read e colaboradores (2005), a do feriado, para verificar o efeito da apresentação em forma de uma data comemorativa, sem números ou menção de dias ou meses. Para garantir que o feriado utilizado correspondesse ao período de três meses em relação ao que o participante estava respondendo ao questionário, o link da pesquisa foi disponibilizado duas vezes, no período de três meses antes de cada um desses feriados, na primeira o feriado era "Dia da Pátria”, e na segunda "Dia das crianças”. O link ficou disponível por três dias em cada uma das vezes, de modo que o tempo aproximado da distância ao cenário hipotético do feriado fosse de três meses.

O segundo instrumento, "Distância da data”, consistiu na medição do tempo subjetivo (baseado no estudo 1 de Zauberman et al., 2009), em que era perguntado ao participante “Quão distante você considera a duração entre hoje e noventa dias?” (cada participante visualizou a mesma forma de apresentação do intervalo de tempo que no instrumento anterior). O participante deveria marcar em uma escala de 1 a 10, em que 1 era "muito curto" e 10 era "muito distante". A escala utilizada era oferecida pelo programa do Google Docs em que foi realizada a pesquisa; pelas limitações do programa, portanto, não se pode utilizar uma medida mais acurada, como a de Zauberman e colaboradores (2009). 
O terceiro instrumento, “Aversão ao Risco”, relacionado com a exposição explícita ao risco, consistiu em sete questões que medem o risco financeiro, ou seja, o quanto que a pessoa se arrisca em situações que envolvem dinheiro (baseadas em trabalho de Kahn \& Sarin, 1988). As sete questões eram quase idênticas, perguntando se a pessoa preferiria ganhar $\mathrm{R} \$$ 50,00 com certeza ou ter a chance de 50\% de ganhar R\$ 800,00. As sete questões só variam o valor do dinheiro que seria ganho com certeza (de $\mathrm{R} \$ 50,00$ a $\mathrm{R} \$ 350,00$, aumentando $\mathrm{R} \$ 50,00$ a cada vez).

O quarto instrumento, Zimbardo Time Perspective Inventory - "ZTPI”, consistiu nas questões do questionário de Zimbardo e Boyd (1999) referentes às dimensões presentehedonístico e futuro. Devido ao questionário ser extenso, e devido às questões das dimensões do passado e do presente fatalista não se relacionarem diretamente com o presente estudo, foram utilizadas somente as questões referentes ao presente-hedonístico e futuro, mais relacionadas ao desconto do futuro, em que presente e passado são as dimensões em foco. Também não foram utilizadas as perguntas relacionadas ao futuro transcendental, que foram desenvolvidas e acrescentadas ao ZTPI posteriormente pelos autores, e são utilizadas em algumas pesquisas e não em outras. O uso de apenas algumas das dimensões e não de todas foi realizado pelos próprios autores em um estudo sobre risco na direção e o tempo presente (Zimbardo, Keough \& Boyd, 1997), em que utilizaram apenas as dimensões do presente e do futuro, e denominaram esse instrumento de versão curta (short version) do ZTPI.

Em um recente estudo sueco, autores acrescentaram ao ZTPI perguntas relacionadas a uma dimensão que denominaram "futuro negativo", que concerne a atitudes pessimistas com relação ao futuro (Carelli, Wiberg \& Wilberg, 2011). Elas não foram acrescentadas nesse estudo porque quando o artigo foi publicado esse projeto já havia sido submetido ao Comitê de Ética, não permitindo modificações. Porém, futuras investigações poderiam se beneficiar dessa nova dimensão descrita.

Quando às dimensões utilizadas, a do presente-hedonístico se refere a uma orientação hedonística em direção ao tempo e à vida, e foi positivamente associada a busca de emoções fortes (sensation seeking) (Zimbardo \& Boyd, 1999), uso de substâncias psicotrópicas (Keough, Zimbardo \& Boyd, 1999), risco na direção (Zimbardo, Keough \& Boyd, 1997) e homens jovens apresentam maiores escores do que mulheres e pessoas mais velhas (Zimbardo et al., 1997). A dimensão do futuro reflete um planejamento para a obtenção de metas, e foi associada positivamente à consideração de conseqüências futuras (Zimbardo \& Boyd, 1999), 
controle percebido, enfrentamento adaptativo (Wills, Sandy \& Waeger, 2001) e as mulheres pontuam mais nessa dimensão do que os homens (Zimbardo \& Boyd, 1999). Foram 28 itens, que o participante respondeu em uma escala tipo Likert de 1 (“Nada a ver comigo”) a 5 (“tudo a ver comigo”). O questionário utilizado foi o adaptado e validado na amostra brasileira por Milfont e colaboradores (2008). As questões referentes ao presente-hedonístico são as seguintes: 17, 19, 20, 22, 23, 25, 27, 29, 30, 32, 34, 36, 38, 42 e 44, que correspondem, respectivamente, às questões 31, 23, 32, 46, 01, 28, 12, 42, 48, 08, 19, 55, 44, 17 e 26 de Milfont e colaboradores (2008). As referentes ao futuro são 18, 21, 24, 26, 28, 31, 33, 35, 37, 39, 40, 41 e 43 que correspondem, respectivamente, às questões 40,13, 10, 56, 21, 09, 24, 06, 18, 30, 51, 45 e 43 de Milfont e colaboradores (2008).

O cálculo do número de pontos para cada dimensão foi feito somando as respostas de cada questão na escala tipo likert de 1 a 5, e depois dividindo pelo número de questões. O resultado é uma média entre 1 e 5 , em que quanto mais próximo do 1 , menos o participante tem a ver com a dimensão, e quanto mais perto do 5 , mais tem a ver com a dimensão.

\subsection{Procedimento}

O questionário foi disponibilizado na Internet através da ferramenta de formulários do Google Docs. Para participar, era necessário ler e aceitar o termo de consentimento livre e esclarecido, em que era dito que o questionário era voluntário e anônimo, além de terem sido disponibilizados os contatos dos pesquisadores e do comitê de ética. Os que clicaram em “Não” (referente a não aceitar as condições da pesquisa), foram encaminhados para uma página de agradecimento e não completaram a pesquisa. A única pergunta obrigatória era a referente ao consentimento, nas demais o participante tinha a possibilidade de deixar questões em branco. O método utilizado foi o da "bola de neve”, em que inicialmente o link era enviado a amigos, e era pedido que esses enviassem a seus amigos, e assim por diante. Aos participantes foi dito se tratar de uma pesquisa sobre comportamento monetário, para evitar muita atenção sobre o tema do tempo. Os quatro grupos experimentais foram separados através do dia do nascimento, para buscar um equilíbrio em sua distribuição. Na página da pesquisa, deveriam indicar uma das seguintes opções de dia do nascimento: “do dia 01 ao dia 
07”, “do dia 08 ao dia 14” e assim por diante, a partir daí foram encaminhados para a página de uma das quatro condições experimentais

\subsection{Análises}

O Google Docs gera uma tabela com os resultados, que somente a pesquisadora teve acesso através de senha. A tabela consistia em colunas, que representavam as perguntas (Gênero, Idade, valor do cupom etc.), e cada linha continha as respostas de um participante. Não houve nenhuma forma de identificação dos participantes, portanto seu caráter anônimo foi mantido. O único dado sobre o acesso do participante ao questionário eram a data e horário em que ele havia enviado as respostas.

Os dados foram passados para uma tabela no programa Statistical Package for Social Sciences (SPSS - versão 18.0). O teste estatístico General Linear Model (GLM) foi utilizado em todas as análises que envolveram diferenças entre os sexos, diferença entre participantes que possuíam ou não filhos, e a comparação entre as quatro condições experimentais. Nas análises que envolveram diferenças de idades, devido à variação entre os resultados nas análises de correlação de Pearson e Spearman, indicando uma relação não-paramétrica entre a distribuição das variáveis, foram utilizados os resultados da Correlação de Spearman. Em todos os casos de comparação de média, a dimensão que envolvia a média era a variável dependente (por exemplo, a taxa de desconto do futuro), e a dimensão comparada, a variável independente (por exemplo, gênero).

A fórmula utilizada para o cálculo da taxa de desconto do futuro, tanto no instrumento “Cenário do cupom”, quanto no "Risco”, foi baseada nos trabalhos de Kirby e Santiesteban (2003):

$\mathrm{K}=$ (Future-tomorrow)/ ((delay in days*tomorrow)- (future)), em que future representa o valor a ser recebido no futuro, tomorrow o dinheiro a ser recebido imediatamente, e delay in days o tempo decorrido até o recebimento do dinheiro no futuro.

O parâmetro k indica o desconto hiperbólico, medindo a indiferença entre receber uma recompensa menor imediatamente (tomorrow) e uma maior no futuro (future). O k é diretamente proporcional à diferença entre o valor de hoje (tomorrow) e o do futuro (future), e 
inversamente proporcional ao atraso (delay). Além disso, é inversamente proporcional ao valor presente - mesmo mantendo-se a diferença entre os valores constantes - pois, por exemplo, o desconto do futuro em que se prefere $\mathrm{R} \$ 100,00$ no futuro ou $\mathrm{R} \$ 50,00$ no presente tem que ser maior do que o desconto do futuro no caso em que se prefere $\mathrm{R} \$ 950,00$ agora ou R\$1.000 no futuro.

No instrumento “Cenário do cupom”, o cálculo do desconto do futuro é realizado através da fórmula, e um K com valor alto significa maior desconto do futuro. No instrumento “Aversão ao risco”, a mesma fórmula é utilizada, porém a estrutura do procedimento é invertida, e o desconto do futuro medido é o desconto probabilístico, desse modo, um número alto de K significa maior aversão ao risco. 


\section{3- RESULTADOS}

\subsection{Análise descritiva geral}

Participaram 208 pessoas, 117 mulheres com idades entre 18 e 61 anos (média = 30,5; desvio $=10,3$ ) e 91 homens, com idades entre 18 e 71 anos (média $=31,3$ e desvio $=$ 11,6). A média de idade, considerando todos os participantes, foi de 30,9 anos, com desvio de 10,9. Como a média foi de 30,9, foram considerados mais jovens os participantes entre 18 e 30 anos. O número total de participantes jovens foi de 133, com média de 24,54 e desvio de 3,09. Desses, 76 (57,14\%) são mulheres, e 57 são homens (42,85\%).

Quanto à escolaridade, 0,5\% possuía ensino fundamental incompleto, 1,4\% ensino fundamental completo, 8,3\% ensino médio completo, 2,4\% ensino técnico, 48,1\% ensino superior e 39,4\% pós-graduação. Não houve correlação entre escolaridade e nenhuma das dimensões estudadas.

Com relação à situação amorosa, 33,2\% eram solteiros, 34,1\% estavam namorando, 26,9\% eram casados e 5,8\% eram divorciados. Não houve correlação entre situação amorosa e nenhuma das dimensões estudadas. A maioria não possuía filhos (78,8\%), somente 21,2\% possuía pelo menos um filho. Dentre as mulheres, 21 possuíam filhos (17,9\%) e 96 não possuíam (82,1\%), e dentre os homens, 23 possuíam filhos (25,3\%) e 68 não possuíam (74,7\%).

Quanto às quatro condições experimentais, 25\% estavam na condição experimental 1 (“noventa dias”), 20,7\% na condição experimental 2 (“três meses”), 30,3\% na condição experimental 3 (“data”) e 24\% na condição experimental 4 (“feriado”). 


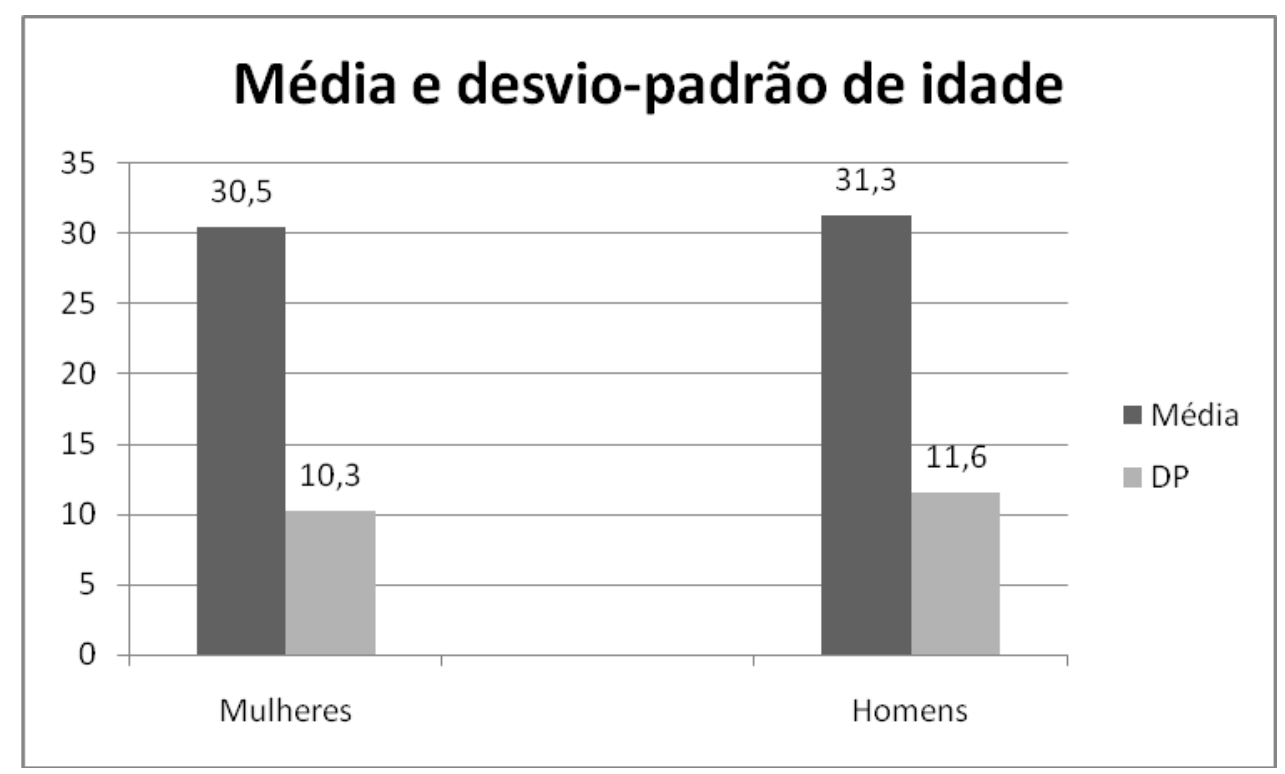

Gráfico 1. Média e desvio-padrão de idade, separados por sexo, de todos os participantes.

\subsection{Cenário do cupom}

\subsubsection{Valor do cupom}

Sete participantes (3,36\%, sendo 6 do sexo feminino e 1 do sexo masculino) responderam que o valor do cupom no futuro seria de R\$100,00, e foram desconsiderados na análise. Três dos participantes (1,44\%, 2 do sexo feminino e 1 do sexo masculino) responderam um valor menor a $\mathrm{R} \$ 100,00$ e também não foram analisados, como em Zauberman e colaboradores (2009). Quando o valor colocado pelo participante para receber no futuro é igual ao oferecido no presente ou menor, o cálculo da taxa de desconto do futuro não é possível, portanto são excluídos da análise. Vinte e um participantes (10,1\%, 14 do sexo feminino e 7 do sexo masculino) responderam um valor muito alto, e também foram desconsiderados da análise. O valor máximo aceito para a análise foi de R\$ $1.800,00$, porque os valores seguintes eram muito distantes. Os valores muito altos e 
distantes dos demais configuraram outliers, ou seja, representaram dados muitos afastados da maioria e poderiam enviesar a análise, sendo prática na estatística excluí-los da análise.

\section{a) Gênero}

Houve uma diferença significativa entre os gêneros quanto ao valor do cupom $\left(\mathrm{F}_{1,175}=\right.$ 8,311; $\mathrm{p}=0,004$; Poder Observado $=0,818$ ), sendo que a mulheres (média $=375,0990 ; \mathrm{N}=$ 101) colocaram maior valor do cupom do que os homens (média = 228,9037; $\mathrm{N}=76$ ).

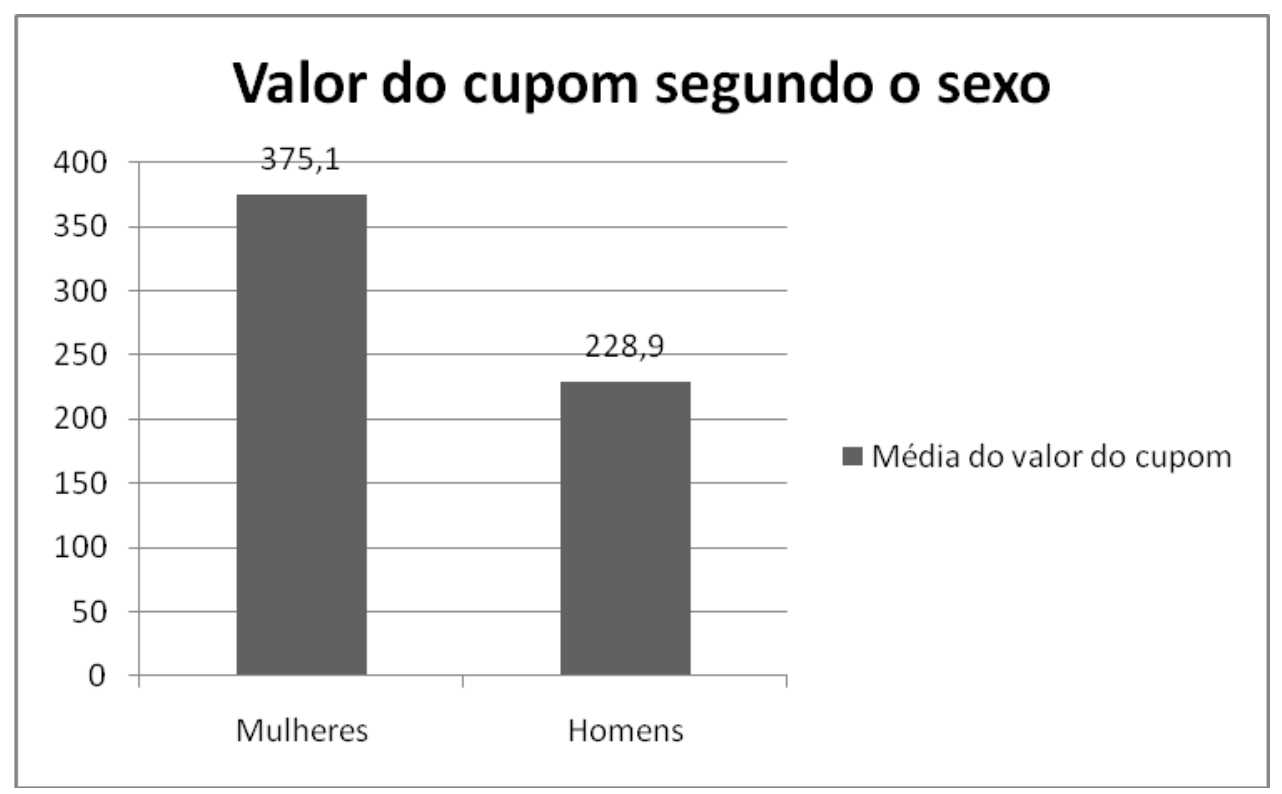

Gráfico 2. Média do valor do cupom segundo o sexo.

\section{b) Idade}

Foi encontrada uma correlação negativa entre idade e o valor atribuído ao cupom $(\mathrm{N}=171 ; \rho=-0,223 ; \mathrm{p}=0,003)$, sendo que os mais jovens atribuíram maiores valores. 


\section{c) Filhos}

Não foi encontrada diferença significativa no valor do cupom $\left(\mathrm{F}_{1,159}=1,612\right.$; $\mathrm{p}=$ 0,206; Poder Observado $=0,243$ ) entre as pessoas que possuem (média $=252,50$ ) ou não (média $=329.79$ ) filhos.

\section{d) Condições experimentais}

Não foi encontrada diferença significativa no valor do cupom $\left(F_{3,173}=0,186 ; p=\right.$ 0,906; Poder Observado = 0,084) entre as condições experimentais: noventa dias (média = 341,49); três meses (média = 303,68); data (média = 291,45); e feriado (média = 313,02).

e) Correlação com os outros instrumentos: “Aversão ao risco”, "Distância da data”, e “ZTPI” ("Presente hedonístico” e “Futuro”)

Não houve correlação entre valor do cupom e os demais instrumentos.

\subsubsection{Taxa de desconto do futuro}

\section{a) Gênero}

Foi encontrada diferença significativa entre os gêneros quanto à taxa de desconto do futuro no cupom $\left(\mathrm{F}_{1,161}=11,510 ; \mathrm{p}=0,001\right.$; Poder Observado $\left.=0,921\right)$, sendo que a mulheres (média =0,033848315; $\mathrm{N}=89$ ) apresentaram-se mais descontadoras que os homens (média = 0,015389189; $\mathrm{N}=74)$. 


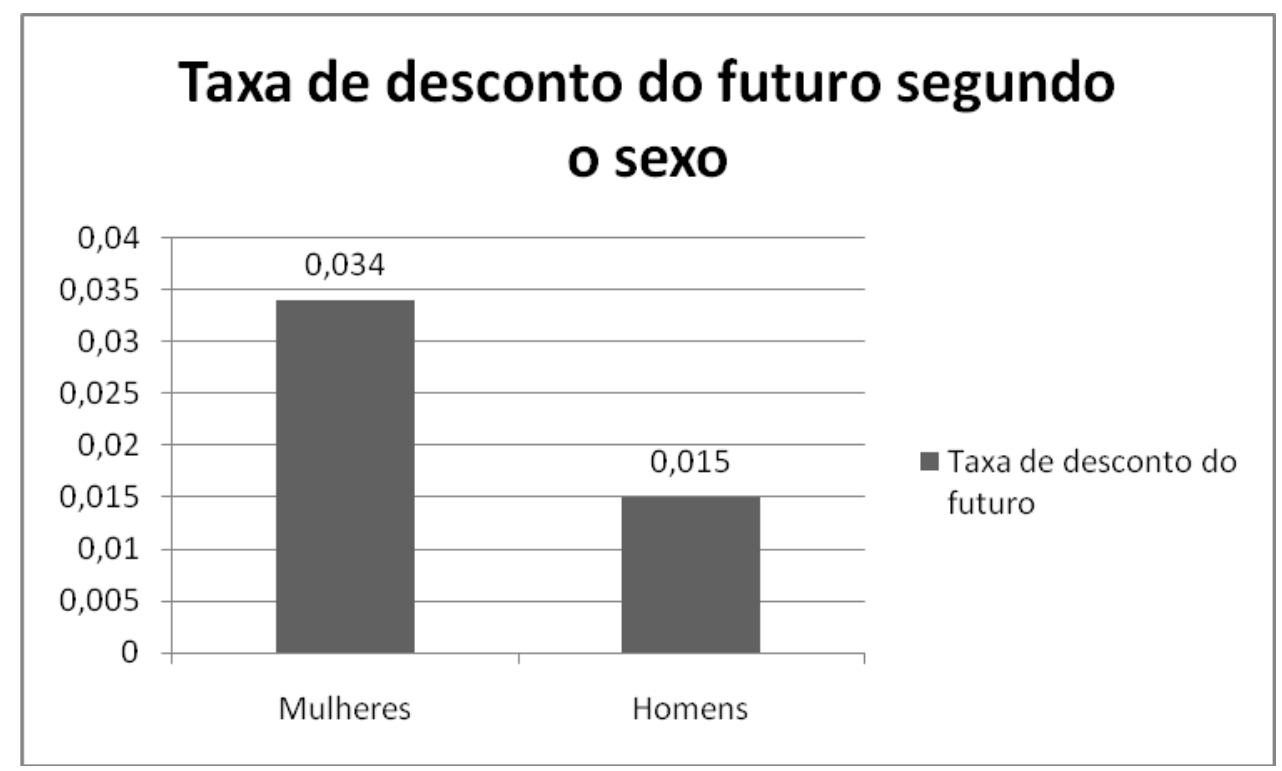

Gráfico 3. Média da taxa de desconto do futuro segundo o sexo.

\section{b) Idade}

Foi encontrada uma correlação negativa entre idade e taxa de desconto do futuro ( $\mathrm{N}=$ 159; $\rho=-0,223 ; p=0,005$ ), sendo que os mais jovens são mais descontadores.

\section{c) Filhos}

Não foi encontrada diferença significativa na taxa de desconto $\left(\mathrm{F}_{1,173}=1,005 ; \mathrm{p}=\right.$ 0,318; Poder Observado $=0,169$ ) entre as pessoas que possuem (média $=0,0183589$ ) ou não (média = 0,0277040) filhos.

\section{d) Condições experimentais}

Não foi encontrada diferença significativa na taxa de desconto $\left(\mathrm{F}_{3,159}=0,078 ; \mathrm{p}=\right.$ 0,972; Poder Observado = 0,064) entre as condições experimentais: "noventa dias" (média = 0,0241310); “três meses” (média = 0,0239117); “data” (média =0,0264000); e "feriado" (média $=0,0271000$ ). 


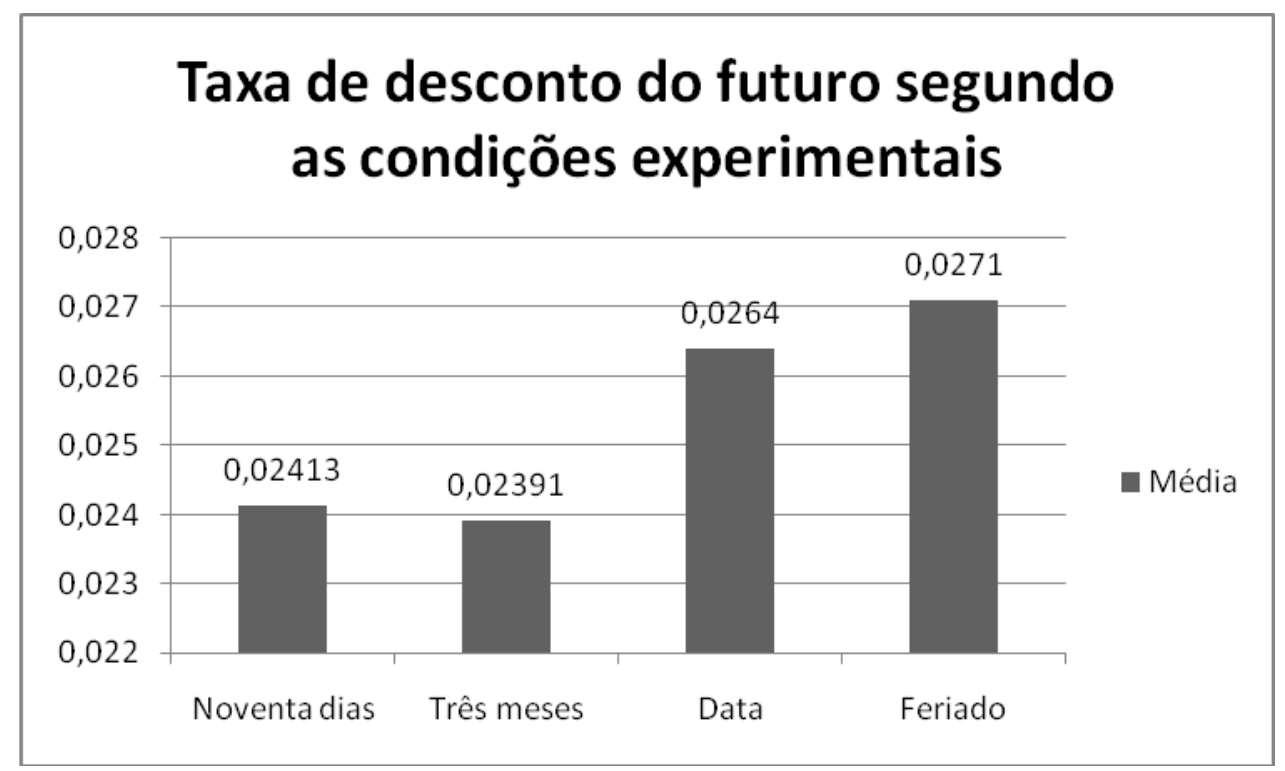

Gráfico 4. Média da taxa de desconto do futuro segundo as quatro condições experimentais, para todos os participantes.

Quando analisadas somente as mulheres, não foi encontrada diferença na taxa de desconto entre as diferentes condições experimentais $\left(F_{3,85}=0,174 ; \mathrm{p}=0,914\right.$; Poder Observado $=0,081)$.

Quando analisados somente os homens, também não foi encontrada diferença na taxa de desconto entre as diferentes condições experimentais $\left(F_{3,70}=1,092 ; p=0,358\right.$; Poder Observado $=0,283$ ).

e) Correlação com os outros instrumentos: “Aversão ao risco”, "Distância da data”, "Presente hedonístico" e "Futuro"

Houve correlação somente com a distância da data, em que quanto maior a taxa de desconto do futuro, maior a distância da data $(\mathrm{N}=163 ; \rho=-0,230 ; \mathrm{p}=0,003)$.

\subsection{Distância da data}


Todos os participantes responderam a essa pergunta, o que indica que ela estava bem formulada. A média encontrada, considerando-se todos os participantes, foi de 4,98 (desvio $=2,19)$.

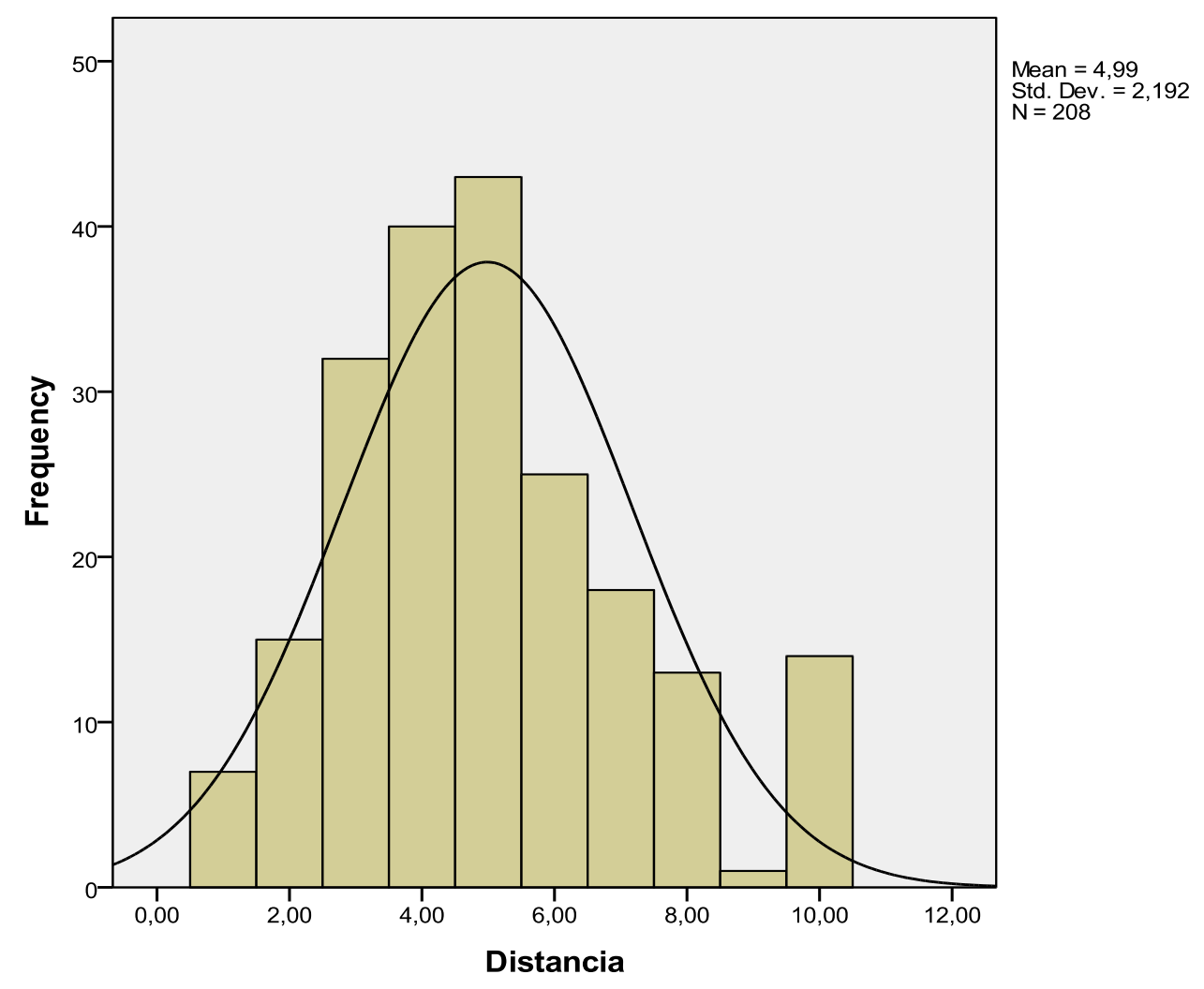

Gráfico 5. Histograma com a curva normal da distribuição dos valores da distância da data, por todos os participantes.

\section{a) Sexo}

Não foi encontrada diferença significativa quanto à distância da data $\left(\mathrm{F}_{1,206}=0,429 ; \mathrm{p}\right.$ =0,766; Poder Observado $=0,060$ ) entre mulheres (média $=5,0256 ; \mathrm{N}=117$ ) e homens (média =4,9340; $\mathrm{N}=91$ ).

\section{b) Idade}

Não foi encontrada correlação entre idade e a distância da data $(\mathrm{N}=203 ; \rho=-0,116$; $\mathrm{P}$ $=0,100)$. 


\section{c) Filhos}

Não foi encontrada diferença significativa na distância da data $\left(\mathrm{F}_{1,204}=2,444 ; \mathrm{p}=\right.$ 0,120; Poder Observado $=0,343$ ) entre as pessoas que possuem (média $=4,52$ ) ou não (média $=5,11$ ) filhos.

\section{d) Condições experimentais}

Foi encontrada diferença significativa na atribuição da distância da data $\left(\mathrm{F}_{3,204}=\right.$ 6,090; $\mathrm{p}=$ 0,001; Poder Observado = 0,958) entre as condições experimentais: "noventa dias" (média = 5,85); “três meses” (média = 4,09); “data” (média = 4,68); e “feriado” (média = 5,24). Testes Post Hoc de Tukey nos mostram que em média os sujeitos da condição experimental de "noventa dias" atribuíram maior distância a hoje do que os sujeitos da condição experimental "três meses” ( $\mathrm{p}<0,001)$ e “data” $(\mathrm{p}=0,019)$, e os sujeitos da condição “feriado” atribuíram distâncias maiores que os sujeitos da condição "três meses” (p = 0,048).

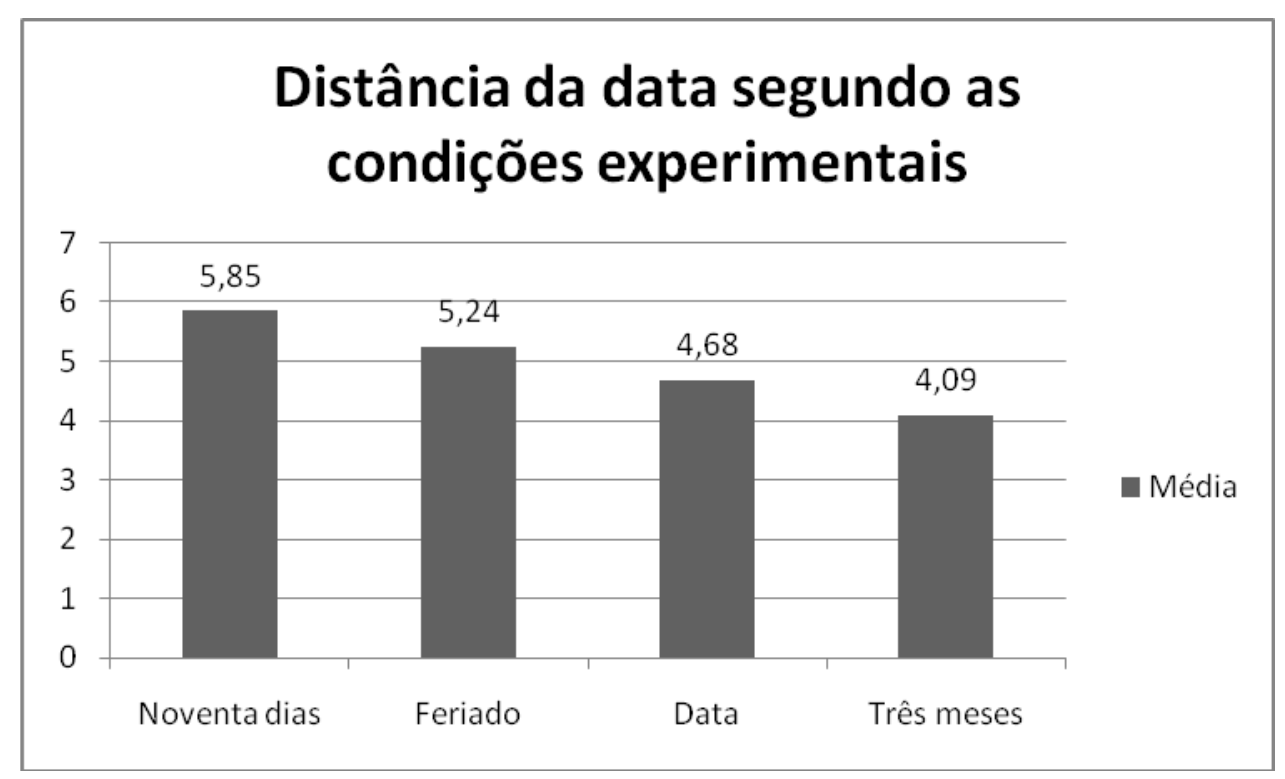

Gráfico 6. Média da distância da data segundo as quatro condições experimentais, para todos os participantes.

e) Correlação com os outros instrumentos: “Cenário do cupom”, “Aversão ao risco", "Presente hedonístico" e "Futuro" 
Houve correlação somente com a taxa de desconto do futuro do "Cenário do cupom", já descrita anteriormente.

\subsection{Aversão ao risco}

No instrumento “Aversão ao risco”, 202 participantes completaram todas as questões e fizeram parte das análises. Quanto maior a média nesse instrumento, maior a aversão ao risco. A média de todos os participantes foi de 0,129394543 (mínimo = 0,0269461; máximo =0,4411765; desvio = 0,1467007739).

\section{a) Gênero}

Foi encontrada diferença significativa entre os gêneros quanto à taxa de aversão ao risco $\left(\mathrm{F}_{1,200}=10,471 ; \mathrm{p}=0,001\right.$; Poder Observado $\left.=0,896\right)$, sendo que a mulheres (média $=$ 0,158071879; $\mathrm{N}=114$ ) apresentaram maior aversão ao risco que os homens (média = 0,092244358; $\mathrm{N}=88$ ).

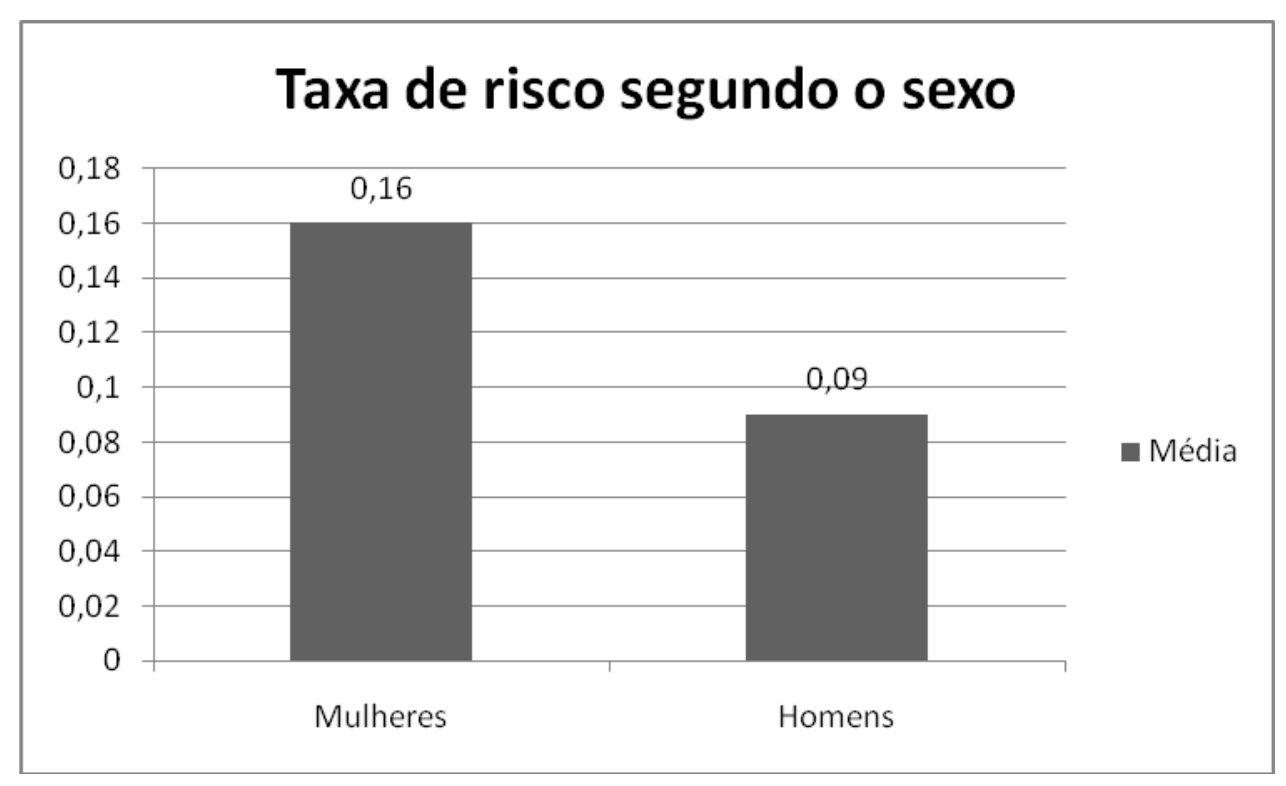

Gráfico 7. Média da taxa de aversão ao risco segundo o sexo. 
b) Idade

Não foi encontrada correlação entre idade e a taxa de aversão ao risco ( $N=197 ; \rho=$ $0,011 ; \mathrm{p}=0,883)$.

\section{c) Filhos}

Não foi encontrada diferença significativa na taxa de aversão ao risco $\left(F_{1,198}=0,298\right.$; $\mathrm{p}=0,586$; Poder Observado $=0,084$ ) entre as pessoas que possuem (média $=0,1127859$ ) ou não (média $=0,1338861$ ) filhos.

\section{d) Condições experimentais}

Não foi encontrada diferença significativa na taxa de aversão ao risco $\left(\mathrm{F}_{3,198}=0,243\right.$; $\mathrm{p}=$ 0,866; Poder Observado = 0,096) entre as condições experimentais: "noventa dias" (média = 0,1354550); “três meses” (média = 0,1288335); “data” (média =0,1365491); e “feriado” (média = 0,1143540).

e) Correlação com os outros instrumentos: “Cenário do cupom”, “Distância da data”, “Presente hedonístico" e "Futuro”

Não houve correlação entre taxa de aversão ao risco e os demais instrumentos.

\subsection{Zimbardo Time Perspective Inventory (ZTPI)}

\subsubsection{Presente Hedonístico}


Com relação ao "Presente hedonístico", 197 participantes completaram todas as perguntas referentes a essa dimensão, permitindo as análises. Os valores poderiam variar de 0 a 5, e a média de todos os participantes foi de 3,05 (mínimo = 1,40; máximo =4,40; desvio = $0,57)$.

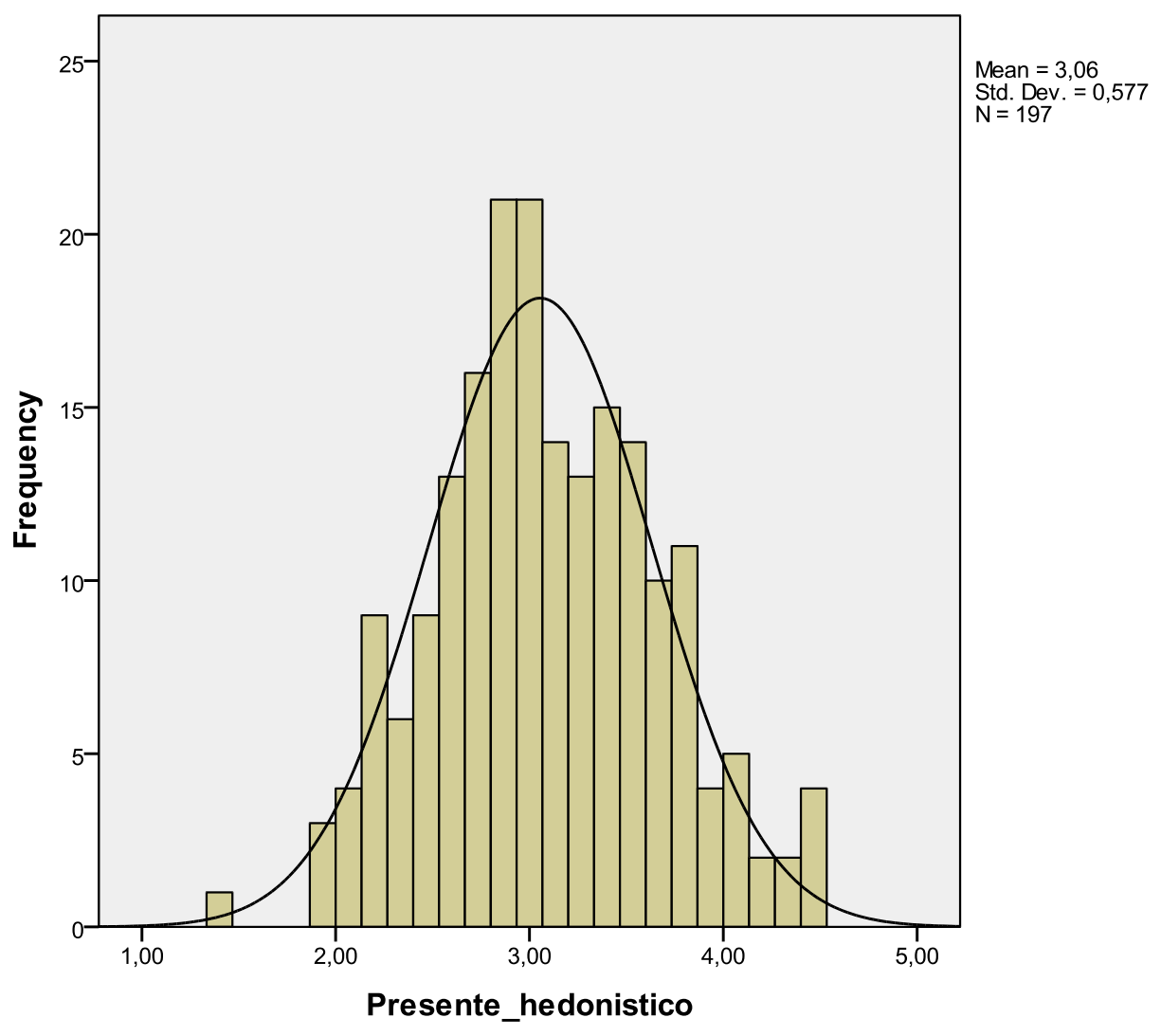

Gráfico 8. Histograma com a curva normal da distribuição dos valores da dimensão "Presente hedonístico”, por todos os participantes.

\section{a) Gênero}

Não foi encontrada diferença significativa quanto à propensão ao tempo presente $\left(F_{1,195}=0,103 ; \mathrm{p}=0,749 ;\right.$ Poder Observado = 0,062) entre as mulheres (média = 3,0667; $\mathrm{N}=$ 112) e os homens (média $=3,0400 ; \mathrm{N}=85$ ).

\section{b) Idade}


Foi encontrada uma correlação negativa entre idade e o presente hedonístico ( $N=193$; $\rho=-0,176 ; p=0,014)$, sendo que os mais jovens são mais propensos ao momento presente.

\section{c) Filhos}

Não foi encontrada diferença significativa no presente hedonístico $\left(\mathrm{F}_{1,193}=0,502 ; \mathrm{p}=\right.$ 0,480; Poder Observado $=0,109$ ) entre as pessoas que possuem (média $=3,01$ ) ou não (média $=3,07$ ) filhos.

\section{d) Condições experimentais}

Não foi encontrada diferença significativa na propensão ao presente $\left(\mathrm{F}_{3,193}=0,195\right.$; $\mathrm{p}$ = 0,899; Poder Observado = 0,086) entre as condições experimentais: "noventa dias” (média = 3,08); "três meses" (média = 3,06); “data” (média = 3,08); e "feriado" (média = 3,00).

e) Correlação com os outros instrumentos: “Cenário do cupom”, “Aversão ao risco”, “Distância da data” e "Futuro"

Houve correlação somente com o futuro ( $\mathrm{N}=190 ; \rho=-0,287 ; \mathrm{p}=0,000)$, que era esperada, em que quanto maior o escore em presente hedonístico, menor o escore no futuro.

\subsubsection{Futuro}


Com relação ao "Futuro", 195 participantes completaram todas as perguntas referentes a essa dimensão, permitindo as análises. Os valores poderiam variar de 0 a 5 , e a média de todos os participantes foi de 3,70 (mínimo = 2,15; máximo = 4,85; desvio =0,55).

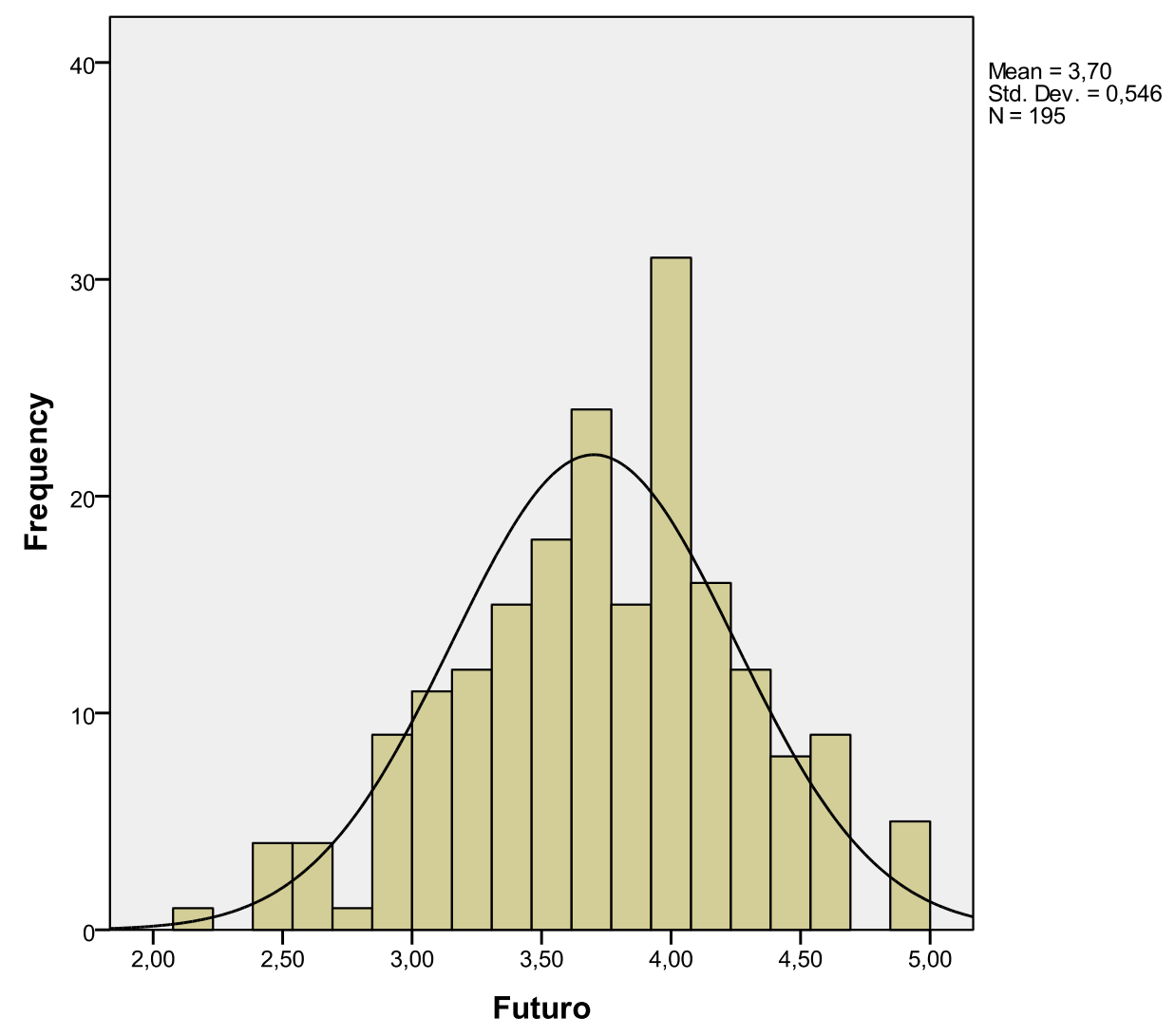

Gráfico 9. Histograma com a curva normal da distribuição dos valores da dimensão "Futuro”, por todos os participantes.

\section{a) Gênero}

Foi encontrada diferença significativa entre os gêneros quanto à propensão ao tempo futuro $\left(\mathrm{F}_{1,193}=8,623 ; \mathrm{p}=0,004\right.$; Poder Observado = 0,832), sendo que a mulheres (média = 3,7988; $\mathrm{N}=112$ ) apresentam-se mais voltadas para o futuro que os homens (média = 3,5709; $\mathrm{N}=83)$. 


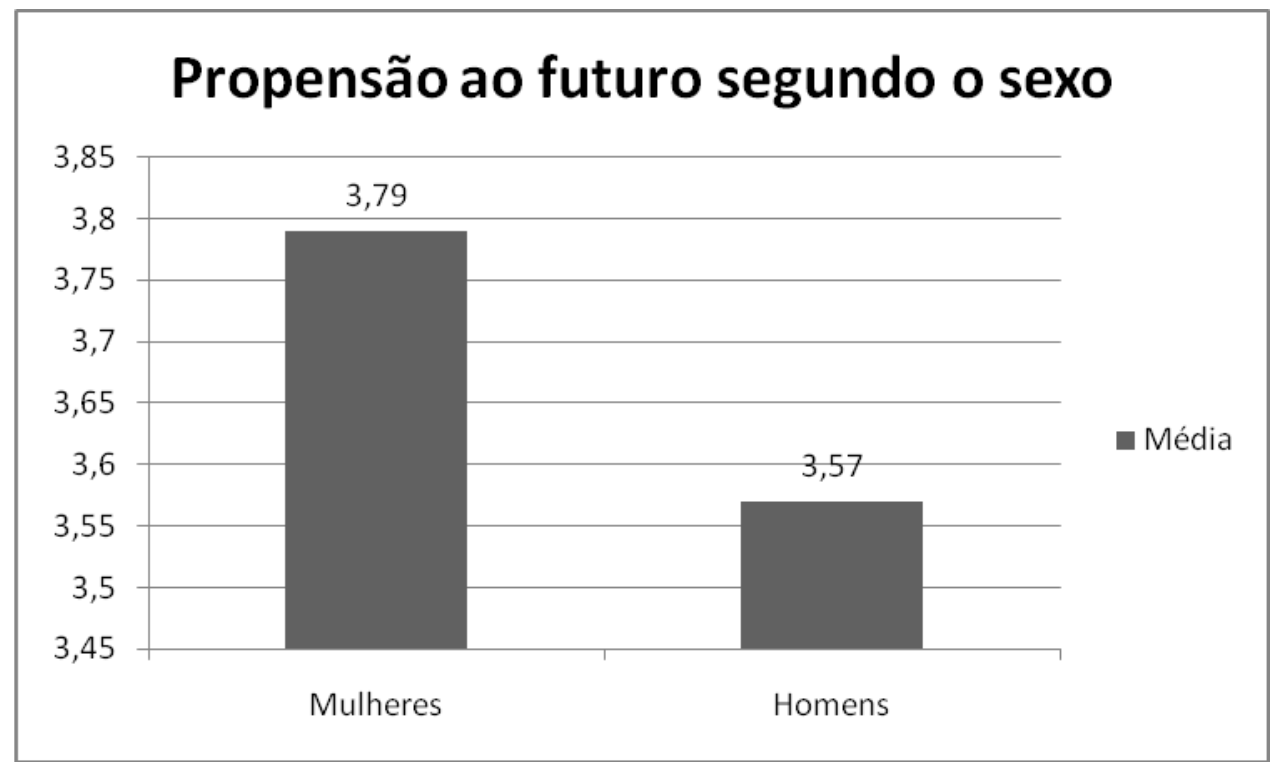

Gráfico 10. Média do escore na dimensão "Futuro” segundo o sexo.

\section{b) Idade}

Foi encontrada uma correlação positiva entre idade e o propensão ao futuro ( $N$ = 191; $\rho=0,170 ; p=0,018$, sendo que os mais jovens são menos voltados para o futuro.

\section{c) Filhos}

Não foi encontrada diferença significativa na propensão ao futuro $\left(\mathrm{F}_{1,191}=2,345 ; \mathrm{p}=\right.$ 0,127; Poder Observado = 0,332) entre as pessoas que possuem (média $=3,89$ ) ou não (média $=3,68)$ filhos.

\section{d) Condições experimentais}

Não foi encontrada diferença significativa na propensão ao futuro $\left(\mathrm{F}_{3,191}=0,092 ; \mathrm{p}=\right.$ 0,964; Poder Observado = 0,066) entre as condições experimentais: "noventa dias" (média = 3,70); "três meses” (média = 3,69); “data” (média = 3,69); e “feriado” (média = 3,74). 
e) Correlação com os outros instrumentos: “Cenário do cupom”, “Aversão ao risco”, “Distância da data” e "Presente-hedonístico"

Houve correlação somente com o "Presente-hedonístico", que era esperada, e já descrita anteriormente. 


\section{DISCUSSÃO}

\subsection{Retomada dos resultados}

Para uma melhor visualização dos resultados para sua discussão, optou-se por organizar os principais resultados em uma tabela.

\begin{tabular}{|c|c|c|c|c|c|}
\hline & $\begin{array}{l}\text { “Cenário do } \\
\text { Cupom" - taxa } \\
\text { de desconto do } \\
\text { futuro }\end{array}$ & $\begin{array}{l}\text { "Distância da } \\
\text { data" }\end{array}$ & $\begin{array}{l}\text { “Aversão } \\
\text { ao risco” }\end{array}$ & $\begin{array}{l}\text { "Presente- } \\
\text { hedonístic } \\
\text { o" }\end{array}$ & "Futuro" \\
\hline $\begin{array}{l}\text { Mulheres } \\
\text { x Homens }\end{array}$ & $\begin{array}{ll}\text { Maior taxa de } \\
\text { desconto } & \text { do } \\
\text { futuro do que os } \\
\text { homens }\end{array}$ & & \begin{tabular}{|ll} 
Maior & \\
aversão & ao \\
risco & do \\
que & os \\
homens &
\end{tabular} & & $\begin{array}{l}\text { Maior } \\
\text { propensão ao } \\
\text { tempo futuro } \\
\text { do que os } \\
\text { homens }\end{array}$ \\
\hline $\begin{array}{ll}\text { Jovens } & \mathbf{x} \\
\text { Mais } & \\
\text { velhos } & \end{array}$ & $\begin{array}{ll}\text { Maior taxa de } \\
\text { desconto } & \text { do } \\
\text { futuro do que os } \\
\text { mais velhos }\end{array}$ & & & \begin{tabular}{|lr} 
Maior \\
propensão \\
ao tempo \\
presente do \\
que res \\
mais \\
velhos
\end{tabular} & \\
\hline $\begin{array}{l}\text { “Cenário } \\
\text { do } \\
\text { cupom” - } \\
\text { as quatro } \\
\text { condições } \\
\text { experimen } \\
\text { tais }\end{array}$ & & $\begin{array}{l}\text { “Noventa dias" } \\
\text { visto como mais } \\
\text { distante do que } \\
\text { "Três meses" e } \\
\text { “data”. "Feriado" } \\
\text { como mais } \\
\text { distante do que } \\
\text { "Três meses". }\end{array}$ & & & \\
\hline $\begin{array}{l}\text { Correlaçã } \\
0 \quad \text { com } \\
\text { outros } \\
\text { instrumen } \\
\text { tos }\end{array}$ & & $\begin{array}{l}\text { Quanto maior a } \\
\text { distância da data, } \\
\text { maior a taxa de } \\
\text { desconto do } \\
\text { futuro }\end{array}$ & & & \\
\hline
\end{tabular}


Tabela 1. Resumo dos principais resultados encontrados.

\subsection{Diferenças de gênero}

As análises indicaram que as mulheres dessa amostra apresentam maior taxa de desconto do futuro, são mais avessas ao risco, e mais propensas à orientação temporal do futuro.

Os resultados referentes à aversão ao risco e à orientação para o futuro têm sido encontrados em pesquisas anteriores, em que as mulheres têm maior aversão a arriscar quando se trata de dinheiro (Hudgens \& Fatkin, 1985; Johnson \& Powell, 1994; Sexton \& BowmanUpton, 1990; Levin et al., 1988; Powell \& Ansic, 1997), e são mais voltadas para a dimensão do futuro descrita por Zimbardo e Boyd (1999).

Já o resultado da taxa de desconto do futuro torna o conjunto de resultados instigante por vários motivos. Em primeiro lugar pela maior taxa de desconto de futuro verificada nas mulheres: apesar de esse resultado ter sido apontado em algumas pesquisas (Logue \& Anderson, 2001; Reynolds et al., 2006), essa não tem sido a regra geral: por exemplo, a metanálise de Silverman (2003) salientou o dado de que as mulheres descontam menos o futuro do que os homens.

Além disso, a junção da maior taxa de desconto com aversão ao risco e propensão ao futuro é até certo ponto inesperada, vide o resultado com jovens que associa alta taxa de desconto do futuro a um perfil de maior propensão ao presente, e sem diferenças quanto à aversão ao risco.

É possível que o maior nível de desconto do futuro das mulheres possa ser mais bem entendido com considerações metodológicas que podem esclarecer a natureza do processo psicológico subjacente. Na presente pesquisa se optou pela forma de medir a taxa de desconto do futuro matching, em que havia uma pergunta aberta, e os participantes deveriam preencher com o valor que quisessem. O cenário era hipotético e não real, em que o indivíduo ganhava um cupom de vale-compras. Nesse exercício de imaginação, em que o respondente poderia colocar qualquer valor, atentando que o enunciado dizia “valor mínimo” (porém livre), as mulheres colocaram valores maiores do que os homens. 
Esse resultado pode ser interpretado de diferentes modos. É possível que, por se tratar de um cupom de compras, as mulheres tenham se interessado mais e colocado um valor mais alto por gostarem mais de compras do que os homens. Em recente pesquisa sobre hábitos de consumo realizada pelo IBOPE no Brasil (2011), 53\% das mulheres concordou totalmente com a frase "Sinto prazer em qualquer tipo de compra” contra 39\% dos homens. Desse modo, o instrumento “Cenário do cupom”, ao apresentar uma situação de compras, pode ter produzido o aparecimento de uma taxa de desconto do futuro que apenas reflete maior interesse por compras por parte das mulheres.

Quando a recompensa é maior os indivíduos tendem a descontar mais o futuro (efeito da magnitude). Talvez nesse caso tenha ocorrido um efeito de magnitude com relação ao cenário de compras: como comprar é mais interessante para a mulher, é como se essa recompensa valesse mais já inicialmente para elas do que para os homens. Assim, essa maior taxa de desconto do futuro seria específica, não necessariamente pode ser transportada para outros contextos.

Outra possibilidade é interpretar a taxa de desconto do futuro maior como uma garantia, já que as mulheres são também mais avessas ao risco. Como preferem a segurança, é possível que para correr o risco de esperar mais tempo peçam mais dinheiro como um contrapeso a esse perigo, como em pesquisa de Guth e Sonsino (2001), em que pessoas mais avessas ao risco eram mais descontadoras. Assim, a conjunção dos dois instrumentos, o do desconto do futuro e o do risco, fornece suporte à hipótese de que pedir mais dinheiro poderia não indicar mais propensão ao presente, e sim maior medo do risco e busca de maior recompensa pelo risco da espera.

As mulheres também apresentaram maior propensão ao tempo futuro pelo ZTPI do que os homens, o que reforça a interpretação de que a taxa de desconto do futuro mais alta encontrada pode não significar maior propensão ao imediato.

Portanto, pode-se trabalhar com várias hipóteses, como a de que a alta taxa de desconto do futuro das mulheres indique uma maior propensão ao presente geral ou específica ao cenário de compras. Ainda, que a maior taxa não represente uma propensão ao imediato, e sim reflita uma aversão ao risco, uma forma de garantir a recompensa.

Também tem que se considerar que se tratava de um cenário hipotético; em Silverman (2003) as mulheres apresentaram menor desconto do futuro, porém em todas as pesquisas 
analisadas as recompensas eram reais. Talvez as mulheres reajam de forma diferente dos homens simplesmente por se tratar de um cenário hipotético, e ainda o contexto de compras pode ter reforçado isso. Contudo, em pesquisa de Kirby e Marakovic (1995), os homens eram mais descontadores em cenários hipotéticos envolvendo dinheiro. Esses resultados fornecem indícios de que o essencial para a diferença na atual pesquisa pode ter sido o cenário de compras, e não o cenário hipotético.

Pode-se questionar se os resultados seriam os mesmos se em vez de se oferecer um cupom de compras fosse oferecido apenas dinheiro. Na metánalise de Silverman (2003) não foram analisadas as situações em que o desconto do futuro era medido, apenas se as recompensas eram reais ou hipotéticas. Não foi encontrada na literatura uma discussão sobre como os instrumentos influenciam na taxa de desconto do futuro com relação ao gênero. Além disso, nem todas as pesquisas apresentaram dados de diferenças entre os gêneros, como em Zauberman e colaboradores (2009), que utilizaram o cenário do cupom. Assim, há pouco foco na diferença entre os gêneros quanto ao desconto do futuro.

O instrumento “Cenário do cupom” pode promover uma diferença entre os gêneros pelo contexto de compras, observação que pôde ser feita nessa pesquisa porque outros instrumentos foram utilizados, como o ZTPI, que aponta para resultados em outra direção.

Tem-se que destacar, porém, que o ZTPI media um tipo de futuro, que pode não ser o mesmo, conceitualmente, que os instrumentos de medida de taxa de desconto do futuro acessam. O futuro no ZTPI é mais relacionado ao cumprimento de obrigações, prazos e metas, planejamento, visão do amanhã, adiamento do prazer. As mulheres são mais conformadas às normas sociais do que os homens (por exemplo, Sistrunk \& McDavid, 1971; Eagly, Wood \& Fishbaugh, 1981), por isso se espera que elas pontuem mais nessa dimensão do que eles, assim como os próprios autores Zimbardo e Boyd (1999) encontraram. Pode-se pensar que justamente por serem mais responsáveis e pensarem mais no amanhã, são mais avessas ao risco, como encontrado no instrumento “aversão ao risco”.

Portanto, tanto em “Aversão ao risco” quanto no ZTPI temos indicações de que as mulheres são menos imediatistas, pensam mais no futuro, adiam o prazer em nome de obrigações, preferem o certo ao incerto, assim, reforçam a hipótese de que a maior taxa de desconto do futuro nessa pesquisa não indica realmente maior propensão geral ao tempo presente, talvez ela seja específica ao cenário de compras ou reflita maior busca de garantia. 


\subsection{Diferenças de idade}

Os jovens, que nessa amostra eram compostos por aproximadamente o mesmo número de homens e mulheres, apresentaram, com relação aos mais velhos, maior taxa de desconto do futuro e maior propensão ao tempo presente. Esse resultado contrasta com o das mulheres, com maior taxa de desconto do futuro, porém maior propensão ao tempo futuro. Ainda os jovens e os mais velhos não apresentaram diferença com relação a aversão ao risco, diferentemente dos resultados das mulheres, em que havia ainda a conjugação de alta taxa de desconto do futuro e propensão ao futuro com maior aversão ao risco.

A literatura aponta que os jovens são mais voltados para o presente, e que ao longo da vida a taxa de desconto do futuro tende a decair (Green et al. 1999), o que foi encontrado nessa pesquisa.

É possível que no caso dos jovens a maior taxa de desconto do futuro realmente represente uma orientação maior ao imediato, já que o instrumento ZTPI apontou nessa direção também. Já no caso das mulheres, que são mais orientadas para o futuro no ZTPI, é possível que a maior taxa de desconto não represente de modo linear ou simples maior propensão ao hoje.

Na literatura os estudos apontam para uma queda no engajamento em situações de risco ao longo da vida (por exemplo, Deakin, Aitken, Robbins \& Sahakian, 2004), porém nessa pesquisa não houve diferença na aversão ao risco quanto à idade. Esse resultado pode reforçar a noção de desconto do futuro e desconto probabilístico como dimensões independentes.

É possível que o “Cenário do cupom” não evoque sentimento de risco, pois não houve apresentação de alguma possibilidade do não recebimento do cupom de compras, mesmo após o tempo de espera. E mesmo que a possibilidade de risco tenha sido evocada, como os participantes mais jovens e mais velhos não apresentaram diferenças na aversão ao risco no outro instrumento que apresentava risco explícito, essa dimensão provavelmente não causou a diferença na taxa de desconto do futuro. Portanto, há indicações de que os mais jovens descontam mais porque são mais voltados para o presente, como o ZTPI indicou, e não 
porque são menos avessos ao risco, porque não houve diferença na aversão ao risco em comparação com os mais velhos.

Portanto, idade foi uma variável importante para explicar diferenças nas dimensões taxa de desconto do futuro e maior propensão ao presente, assim como encontrado em literatura anterior, o que reforça a noção de que a maior taxa de desconto do futuro está relacionada com imediatismo e super valorização do presente, e não com alguma relação com o risco, porque não foi encontrada diferença na aversão ao risco entre mais jovens e mais velhos.

Quanto ao instrumento “Aversão ao risco”, nessa pesquisa as mulheres são mais avessas ao risco do que os homens e não houve diferença quanto à idade. Na discussão sobre a relação entre desconto probabilístico, aqui entendido como aversão ao risco e desconto do futuro tratada por Green e Myerson (2004), os autores afirmam que na maioria dos estudos realizados, variáveis afetavam as duas formas de desconto de modo diferente, sugerindo que são dois fenômenos separados e não diferentes partes do mesmo fenômeno. Nessa pesquisa, o gênero afetou ambas as formas de desconto, mas a idade não. Portanto, a variável gênero correlacionou com ambas as formas de desconto, indicando uma possível relação entre elas, porém a idade correlacionou somente com uma delas, reforçando a independência das duas formas de desconto.

É possível que no caso da diferença entre homens e mulheres a maior aversão ao risco por elas tenha desempenhado um papel na maior taxa de desconto do futuro, em que seria uma forma de garantir o recurso. Já no caso da diferença de idade, a aversão ao risco não parece explicar a alta taxa de desconto do futuro, e sim uma maior propensão ao tempo presente, a uma maior vontade de usufruir o recurso agora, e não preocupação com se ele existirá amanhã. Na conjugação com outras variáveis, como gênero e idade, a relação entre desconto do futuro e aversão ao risco não é tão simples, sugerindo que a interação entre todas essas dimensões é complexa e depende de uma configuração de fatores.

As duas dimensões do desconto do futuro descritas por Anderhub e colaboradores (2001), a do prazer imediato ao consumir o bem e a de evitar o risco de perdê-lo posteriormente aparecem de maneiras diferentes em homens e mulheres e em mais jovens e mais velhos. Para as mulheres, é possível que o crucial em descontar o futuro seja a garantia, como a maior aversão ao risco sugere, e para os mais jovens, o crucial pode ser o prazer de consumir imediatamente, como a maior propensão à orientação temporal do presente no ZTPI sugere. 
Sobre a taxa de desconto do futuro e outras variáveis pesquisadas, como ter ou não filhos, situação amorosa e escolaridade, não houve correlação entre elas. Assim, nessa pesquisa, com relação ao perfil dos participantes, somente as variáveis gênero e idade explicaram diferenças na taxa de desconto do futuro.

\subsection{Diferenças na percepção subjetiva temporal entre os quatro grupos experimentais em "distância da data”}

Quanto a diferenças na percepção subjetiva do intervalo de tempo de três meses apresentado de diferentes formas, não foram encontradas diferenças significativas nos quatro grupos experimentais (“noventa dias”, "três meses”, “data” e "feriado”) entre homens e mulheres, idades diferentes, possuir ou não filhos, escolaridade e situação amorosa. Desse modo, essas variáveis não se relacionaram com diferenças na percepção subjetiva de uma distância temporal. Contudo, foram encontradas diferenças entre as condições experimentais, em que o grupo "noventa dias” atribuiu maior distância a hoje do que o grupo "três meses” e “data”, e o grupo “feriado” atribuiu distância maior que o grupo "três meses”.

Read e colaboradores (2005) encontraram que quando o tempo a ser esperado é escrito em forma de data há menos desconto do futuro, o date/delay effect. Uma das hipóteses para explicar o fato é que a data é percebida como mais próxima ao hoje do que quando o tempo é descrito em atraso, em que fica claro o tempo a ser decorrido até que o participante consiga o prêmio. Em nosso estudo, somente o grupo “noventa dias” apresentou percepção subjetiva de maior distância comparando com a data, o que seria esperado que também ocorresse com o grupo "três meses”. Uma hipótese para explicar esse dado é que o número "noventa” é maior do que "três", o que evoca uma distância maior, como se o complemento "dias" e "meses" tivesse sido negligenciado.

Alguns estudos têm sido realizados na área de processamento de estímulos numéricos e podem auxiliar na interpretação desse resultado. Quando um número é seguido de uma unidade (por exemplo, R\$ ou kg) sendo a unidade familiar ou desconhecida, a tendência é nossa atenção se voltar para a magnitude do número e desconsiderar a unidade (por exemplo, Jacobs \& Kruschke, 2011). Se a unidade é familiar, o que importa realmente é o número, porque já se sabe a grandeza que ele representa. Entretanto, no caso da unidade ser 
desconhecida, ela deveria ser identificada porque sem essa informação o número não pode ser interpretado, porém nossa atenção se volta apenas para o número, talvez porque seja mais fácil de entendê-lo do que a unidade. Essa tendência a ignorar a unidade é chamada de “cegueira deliberada” (deliberational blindness) e não é uma falha perceptual, e sim uma falha na compreensão (Metcalfe \& Wiebe, 1987).

A “cegueira deliberada” às unidades “dias” e “meses” pode ter ocorrido, e a atenção ter se voltado para os números, mesmo as unidades tendo sido apresentadas e serem familiares. Como "noventa” representa um número mais do que "três", pode ter sido considerado mais distante, já que a unidade não recebeu atenção e não entrou nos cálculos do tempo total.

Quanto ao grupo “feriado”, queríamos investigar se uma data relacionada a um acontecimento (nesse caso, a um feriado), representaria alguma diferença com relação a outras formas de escrita de datas. A percepção subjetiva foi de maior distância, e somente em comparação à condição “três meses”. Ocorreu um efeito oposto ao esperado, pois o tempo corrido (três meses) foi percebido como menos distante que um tempo pontual (feriado). É possível que um feriado, por não conter números, apenas um conteúdo relativo a uma comemoração, seja percebido como mais distante por ser menos localizado do que uma data.

\subsection{Desconto do futuro e distância subjetiva da data}

Diferentemente dos estudos anteriores, não foi encontrada diferença na taxa de desconto do futuro entre as quatro condições experimentais ("noventa dias”, "três meses", “data” e “feriado”), portanto o date/delay effect descrito por Read e colaboradores (2005) não foi encontrado.

Contudo, quando os dados do instrumento “distância da data” são analisados em conjunto, aparece uma correlação entre a taxa de desconto do futuro e a percepção subjetiva da data. Trata-se de uma correlação positiva, assim quanto maior a taxa de desconto do futuro maior a distância subjetiva atribuída ao intervalo de tempo, e vice-versa.

Por se tratar de uma correlação, não é possível saber qual é a causa e qual a consequência. Esse resultado sugere que a) as pessoas que veem o futuro como mais longe do presente são mais imediatistas, ou que b) as pessoas mais imediatistas acabam vendo o futuro 
como mais longe. Ainda, é possível que c) um terceiro fenômeno afete essas duas variáveis conjuntamente ou separadamente, causando a) ou b).

A hipótese a) parece representar a visão de Zauberman e colaboradores (2009), em que o indivíduo que percebe subjetivamente um determinado período de tempo como mais distante tende a preferir o presente ao futuro. Talvez o self futuro estaria muito distante e representaria uma ligação ainda mais fraca com o self do presente, que teria maior vantagem e seria preferido. Ou um tempo maior represente mais espaço para mudanças, que tornariam mais inseguro o acesso ao recurso, daí a preferência pelo presente.

Também é possível o inverso, descrito na hipótese b): que o indivíduo que tende a preferir o tempo presente, sendo mais descontador, percebe um intervalo de tempo como muito distante. A maior distância subjetiva temporal seria consequência, e não causa do desconto. Talvez para o imediatista o foco no presente faça com que o futuro seja percebido como distante, menos relacionado a ele, pela atenção estar no agora.

No caso da hipótese c), a variável que afetaria essas duas dimensões provavelmente não seria as que foram estudadas nessa pesquisa, como gênero e idade, pois não demonstraram correlação com o desconto do futuro e ao mesmo tempo com a distância subjetiva da data. Fatores como personalidade e história de vida podem ser causas de diferenças na taxa de desconto do futuro, como algumas pesquisas citadas na Introdução indicaram. Podem também afetar a percepção subjetiva de futuro, porém mais estudos precisam ser feitos nessa área. Caso uma terceira variável afete essas duas dimensões, fortalece-se a hipótese de que são partes do mesmo fenômeno, por exemplo que a alta taxa de desconto do futuro sempre envolve a percepção subjetiva temporal como mais distante e vice-versa.

Seja qual for a direção da relação entre essas duas dimensões, a percepção subjetiva de tempo está relacionada à taxa de desconto do futuro do indivíduo, como Zauberman e colaboradores (2009) sugeriram. Deve-se ressaltar, contudo, que os participantes responderam ao instrumento “Distância da data” após o “Cenário do cupom”, em que o intervalo de tempo de noventa dias estava vinculado ao recebimento do cupom no futuro, com valor a ser preenchido pelo respondente. Portanto, houve uma aproximação entre esse intervalo de tempo e um valor monetário; não se tratou de uma distância temporal qualquer, havia a conjugação com um cenário em que dinheiro estava envolvido. Pode ter ocorrido uma ilusão de foco (focusing illusion), em que o tema dinheiro apresentado imediatamente antes da percepção temporal pode ter feito com que essa percepção subjetiva de tempo ficasse muito relacionada 
ao dinheiro, e não a outros fatores. Sugere-se que estudos sejam feitos envolvendo a percepção subjetiva de tempo e o desconto do futuro com recompensas não monetárias.

De qualquer forma, esse resultado encoraja novas explorações sobre como a percepção subjetiva de tempo se relaciona com a taxa de desconto do futuro. Embora os autores Read e colaboradores (2005) sugiram que o tempo a ser considerado nos estudos do desconto do futuro deva ser o subjetivo, nessa pesquisa as dimensões taxa de desconto do futuro e percepção subjetiva de tempo parecem caminhar juntas: quando a taxa de desconto do futuro é maior, a distância temporal é percebida como mais distante e vice-versa. E isso independentemente da forma de apresentação do tempo de espera, portanto há indícios de que essa forma de apresentação não é algo essencial, pelo menos em se tratando do mesmo intervalo de tempo.

Em Zauberman e colaboradores (2009), a percepção subjetiva de tempo era mais contraída conforme a distância temporal aumentava, assim três anos eram subjetivamente semelhantes a um ano. Nesse estudo, não foram comparados diferentes intervalos de tempo, e sim o mesmo intervalo apresentado de diferentes formas. O objetivo era verificar se a forma de apresentação do tempo interferia na taxa de desconto do futuro, e ainda se havia diferenças individuais na taxa de desconto e na percepção subjetiva de tempo.

Em nosso estudo, o que foi mais notável não foi a forma de apresentação do intervalo de tempo, e sim a relação entre maior taxa de desconto do futuro e maior percepção subjetiva de tempo em geral. Ou seja, elas estão relacionadas, e naqueles indivíduos que vêem o futuro como mais distante a taxa de desconto do futuro é maior, e vice-versa. Mais estudos são necessários para entender a relação entre essas duas dimensões, se são independentes ou partes do mesmo fenômeno.

\subsection{Discussão geral}

Ao estudar o fenômeno do desconto do futuro e a percepção de tempo, nossa principal hipótese era a de que diferentes formas de apresentação do mesmo intervalo de tempo influenciariam na taxa de desconto do futuro, por representar diferentes percepções subjetivas de distância temporal. Nessa amostra brasileira, entretanto, a forma como o período de tempo 
a ser esperado pela recompensa era descrito não influenciou na taxa de desconto do futuro dos participantes.

Contudo, foi encontrada uma correlação positiva entre taxa de desconto do futuro e distância subjetiva da data em geral, juntando-se os quatro grupos e independente da apresentação, o que sugere uma relação entre essas duas dimensões, que tem sido pouco explorada. As pessoas que vêem o futuro como mais distante descontam mais o futuro, e viceversa, porém não se pode afirmar qual é a causa e qual a consequência.

Além da distância subjetiva temporal, as variáveis gênero e idade foram as únicas que correlacionaram com diferenças na taxa de desconto do futuro, dados já encontrados em literatura anterior. Contudo, o instrumento "Cenário do cupom” pode não ter sido adequado para acessar a taxa de desconto do futuro dos participantes quando se considera o gênero, já que outros fatores podem ter causado o maior valor pedido, e não uma maior propensão ao presente. As mulheres pontuaram mais na propensão ao futuro pelo ZTPI, e apresentaram maior aversão ao risco, dados que indicam uma menor propensão ao imediato, contrariando o resultado da alta taxa de desconto do futuro e apoiando a hipótese de que essa alta taxa não representa maior propensão ao presente.

Os mais jovens pontuaram mais na propensão ao presente do ZTPI, e não apresentaram diferença quanto a aversão ao risco, indicando que a maior taxa de desconto do futuro se relaciona com maior valorização do presente, e não com diferenças quanto à propensão a se arriscar.

Diferenças na distância subjetiva temporal do atraso indicam que números maiores em datas podem enviesar a percepção para o sentido de serem mais distantes subjetivamente, independentemente da unidade que segue ao número, devido à “cegueira deliberada”. Assim, em “noventa dias” a percepção subjetiva foi de tempo mais distante do que "três meses", apesar de se tratarem da mesma distância objetiva.

Pesquisas futuras poderiam explorar as diferenças de gênero que os instrumentos de desconto do futuro podem causar e chamar a atenção para esse fato, já que a dimensão gênero é pouco considerada e debatida nos estudos sobre desconto do futuro.

A relação entre desconto do futuro e percepção subjetiva de tempo deve ser mais explorada, por exemplo, em questões como cenários não monetários, e se a relação entre essas dimensões é de causa e consequência ou se são parte do mesmo fenômeno. 


\subsection{Reflexões sobre o método}

Um número grande de pessoas respondeu à pesquisa no pouco tempo em que o link esteve disponível, o que reforça o fato de a Internet ser uma boa ferramenta para pesquisas com questionários. Um viés de amostragem, porém, ocorreu com relação à escolaridade dos participantes, que na maioria possuía ensino superior completo e um grande número possuía pós-graduação, números acima da porcentagem da população em geral. Isso pode ter ocorrido devido à divulgação do link em e-groups da pós-graduação, além de que os conhecidos da pesquisadora, para quem o link foi enviado, em geral têm alto nível de educação formal.

De acordo com o site do Instituto Brasileiro de Geografia e Estatística (IBGE), em 2009 a média de anos de estudo da população brasileira era de apenas 7,4, o que corresponde a ensino fundamental. Portanto, a grande participação de pessoas em pós-graduação nessa pesquisa não reflete a realidade da população brasileira.

A distribuição nas quatro condições experimentais foi equilibrada, indicando que o método de separar os participantes através do dia do nascimento é eficaz. Também houve participação semelhante entre homens e mulheres. Quanto à idade, também houve bastante distribuição, o que nos permitiu análises de comparação entre mais jovens e mais velhos. A grande maioria dos respondentes não possuía filhos, possivelmente porque a idade média dos participantes era por volta dos 30 anos. Foi possível, contudo, realizar análises comparando

participantes com e sem filhos. Algumas das desvantagens da aplicação pela Internet podem ser apontadas, como a incerteza de que o participante forneceu dados verdadeiros, a impossibilidade de controle de que um mesmo participante respondesse mais de uma vez modificando alguns dados, e a impossibilidade do participante solucionar alguma dúvida durante o preenchimento do questionário. Nesse último caso, destaca-se a pergunta do instrumento "Cenário do Cupom”, que pode não ter sido compreendida por muitos participantes. A tarefa de matching apresenta maior nível de dificuldade do que a de “escolha”, porque é o participante que tem que colocar o valor, sem ter nenhum exemplo antes. Nesse caso, houve dificuldade de entendimento por muitos participantes, e pela pesquisa ter sido realizada na Internet, não havia a possibilidade de sanar as dúvidas e explicar como o participante deveria proceder. Pode-se pensar, para uma próxima aplicação, 
na reformulação do texto da pergunta, de modo a diminuir o mau entendimento. Talvez a tarefa de "escolha” seja mais apropriada na aplicação online, as vantagens e desvantagens devem ser pesadas pelos pesquisadores antes de optar por uma das formas, de acordo com o procedimento de sua pesquisa.

Outra possível desvantagem no uso da Internet é uma maior probabilidade de o participante não levar a pesquisa a sério, como no “Cenário do Cupom”, em que alguns participantes responderam um valor muito alto para o cupom, bastante distante do razoável, talvez em tom de brincadeira.

\subsection{Limitações do Estudo}

Houve um viés de amostragem, em que muitas pessoas com alto nível de escolaridade representaram mais da metade da amostra, não refletindo a situação do país. Isso limita a extensão dos resultados à população brasileira. O método "bola de neve” pode fazer com que apenas pessoas semelhantes respondam à pesquisa, já que repassam o link a amigos.

A pergunta do instrumento "Cenário do Cupom” gerou muitas respostas equivocadas, sugerindo que uma reformulação poderia fazer com que mais pessoas compreendessem a questão. Ou talvez a forma de "escolha" seja mais adequada do que a de matching para o cálculo do desconto do futuro em questionários online, já que geram menos dúvida. O cenário de compras pode ter favorecido às mulheres se interessar mais e colocar valores maiores, modificando a taxa de desconto do futuro. Para pesquisas futuras, deve-se tentar um cenário que não evoque tantas diferenças de gênero. Apesar de ter se tentado uma aproximação com a realidade, pode ser que os participantes, ou muitos deles, não tenham se comportado de um modo próximo a como se comportariam se fosse uma situação real.

Os resultados devem ser interpretados à luz dos instrumentos utilizados, portanto com seu referencial teórico e suas limitações. 


\section{REFERÊNCIAS}

Ainslie, G. (1975). Specious Reward: A Behavioral Theory of Impulsiveness and Impulse Control. Psychological Bulletin, 82(4), 463-469.

Ainslie, G. (1992). Picoeconomics: The Strategic Interaction of Successive Motivational States within the Person. New York: Cambridge University Press.

Akerlof, G. A. (1991). Procrastination and Obedience. American Economic Review, 81(2), 119.

Anderhub, V., Guth, W., Gneezy, U., \& Sonsino, D. (2001). On the Interaction of Risk and Time Preferences: An Experimental Study. German Economic Review, 2(3), 239-253.

Ariely, D. \& Loewenstein, G. (2000). When Does Duration Matter in Judgment and Decision Making. Journal of Experimental Psychology: General, 129, 508-523.

Barber, B. M. \& Odean, T. (2001). Boys will be boys: gender, overconfidence and common stock investment. Quarterly journal of economics, 262-292.

Bargh, J.A. (Ed.) (2006). Social psychology and the unconscious: The automaticity of higher mental processes. Psychology Press; Philadelphia.

Baron, J. (2008). Thinking and deciding. Cambridge University Press.

Bettman, J. R., Johnson, E., \& Payne, J. W. (1991). Consumer Decision Making. In: T. S. Robertson, \& H. Kassarjian, Handbook of Consumer Behavior. New Jersey: Prentice Hall.

Bjorklund, D. E, \& Kipp, K. (1996). Parental investment theory and gender differences in the evolution of inhibition mechanisms. Psychotogicat Butletin, 120, 163-188.

Carelli, M.G., Wiberg, B., \& Wiberg, M. (2011). Development and Construct Validation of the Swedish Zimbardo Time Perspective Inventory. European Journal of Psychological Assessment, 27(4), 220-227. 
Carstensen, L., Isaacowitz, D. M. \& Charles, S. T. (1999). Taking Time Seriously: A Theory of Socioemotional Selectivity. American Psychologist, 54(3), 165-81.

Chapman, G. B., \& Sonnenberg, F. A. (2000). Decision making in health care: Theory, psychology, and applications. New York: Cambridge University Press.

Chen, T., Kalra. A. \& Sun, B. (2009). Why do consumers buy extended service contracts. Journal of Consumer Research, 36, 611-623.

Cosmides, L. \& Tooby, J. (1994). Better than rational: evolutionary psychology and the invisible hand. The American economic review, 84(2), 327-332.

Cosmides, L. \& Tooby, J. (2005). Neurocognitive adaptations designed for social exchange. In D. M. Buss (Ed.), The handbook of evolutionary psychology.

Daly, M., \& Wilson, M. (1988). Homicide. Aldine de Gruyter: Hawthorne, NY.

Daly, M. \& Wilson, M. (2005). Carpe Diem: Adaptation and Devaluing the Future. The Quarterly Review of Biology, 80, 55-60.

Damasio, A.R. (1994) O erro de Descartes: emoção, razão e o cérebro humano. Companhia das Letras.

De Wit, H., Flory, J. D., Acheson, A., McCloskey, M., \& Manuck, S. B. (2007). IQ and nonplanning impulsivity are independently associated with delay discounting in middle-aged adults. Personality \& Individual Differences, 42, 111-121.

Deakin, J. Aitken, M. Robbins, T. \& Sahakian, B.J. (2004). Risk taking during decisionmaking in normal volunteers changes with age. Journal of the International Neuropsychological Society, 10, 590-598.

Dehaene, S., \& Cohen, L. (1995). Towards an anatomical and functional model of number processing. Mathematical cognition, 1(1), 83-120. 
Fehr, E. (2002). The economics of impatience. Nature, 415, 269-272.

Eagly, A. H., Wood, W., \& Fishbaugh, L. (1981). Sex differences in conformity: Surveillance by the group as a determinant of male nonconformity. Journal of Personality and Social Psychology, 40, 384-394.

Ebert, J.E.J. \& Prelec, D. (2007). The fragility of time: time-insensitivity and valuation of the near and far future. Management Science, 53(9), 1423-1438.

Eysenck,S.B.G., Eysenck, H.J. \& Barret, P. (1985). A revised version of the psychoticism scale. Personality and individual differences, 6(1), 21-29.

Fischoff, B., \& Beyth, R. (1975). “I knew it would happen” Remembered probabilities of once-future things. Organizational Behaviour and Human Performance, 13, 1-16.

Fodor, J. (2000). The mind doesn't work that way: the scope and limits of computational psychology. Cambridge, MA: MIT Press.

Frederick, S., Loewenstein, G. \& O’Donoghue, T. (2003). Time discounting and time preference: a critical review. In Loewenstein, Read, and Baumeister, (eds.), Time and Decision, 13-86.

Frederick, S. \& Shafir, E. (2004). (no prelo) Careless Choice and Mindless Matching: Elusive Attribute Weights in Preference Elicitation. Massachusetts Institute of Technology.

Fredrickson, B.L. \& Kahneman. D. (1993). Duration Neglect in Retrospective Evaluations of Affective Episodes. Journal of Personality and Social Psychology, 65, 44-55.

Gerber, L.R., Reichman, O.J, \& Roughgarden; J.(2003) Food hoarding: future value in optimal foraging decisions. Ecological modeling, 175(1), 77-85.

Graham, R. J. (1981). The Role of Perception of Time in Consumer Research. Journal of Consumer Research, 7, 335-42. 
Green, L., Fristoe, N.,\& Myerson, J. (1994). Temporal discounting and preference reversals in choice between delayed outcomes. Psychonomic Bulletin \& Review, 1, 383-389.

Green, L., Fry, A.F. \& Myerson, F. (1994). Discounting of delayed rewards: A life-spam comparison. Psychological Science, 5(1), 33-36.

Green, L.,\& Myerson, J. (1996). Exponential versus hyperbolic discounting of delayed outcomes: Risk and waiting time. American Zoologist, 36, 496-505.

Green, L. \& Myerson, J. (2004). A Discounting framework for choice with delayed and probabilistic rewards. Psychological Bulletin, 130(5), 769-792.

Green, L., Myerson, J. \& Ostaszewski, P. (1999). Discounting of delayed rewards across the life span: age differences in individual discounting functions. Behavioural Processes, 46(1), 89-96.

Haipeng, A. C., Sharon, N.G. \& Akshay, R. R. (2005). Cultural Differences in Consumer Impatience. Journal of Marketing Research, 291, 291-301.

Hartog, J., Ferrer-i-Carbonell, A., \& Jonker, N. (2002). Linking measured risk aversion to individual characteristics. Kyklos, 55(1), 3-26.

Haselton, M.G., Bryant, G.A., Wilke, A., Frederick, D.A., Galperin, A., Frankenhuis, W.E. et al. (2009). Adaptive rationality: an evolutionary perspective on cognitive bias. Social cognition, 27(4), 732-762.

Haselton, M.G. \& Buss, D. (2000). Error management theory: a new perspective on biases in cross-sex mind reading. Journal of personality and social psychology, 78, 81-91.

Hofstede, G. \& Bond, M. H. (1988). The Confucius Connection: From Cultural Roots to Economic Growth. Organizational Dynamics, 16(4), 4-18.

Houston, A., Kacelnik, A., \& McNamara, J. (1982). Some learning rules for acquiring information. In D. McFarland (Ed.), Functional ontogeny (pp. 140-191). Boston: Pitman. 
Hsee, C. K. (2000). “Attribute Evaluability and Its Implications for Joint-Separate Evaluation Reversals and Beyon" em Choices, Values and Frames, Daniel Kahneman e Amos Tversky, eds. Cambridge, UK: Cambridge University Press, 543-63.

Hudgens, G. \& Fatkins, L. (1985). Sex differences in risk taking: Repeated sessions on a computer simulated task. Journal of Psychology, 119(3).

Ibope mídia revela hábitos de saúde e consume da mulher brasileira. Recuperado em 05 de fevereirro de 2012 de: http://www.ibope.com.br/calandraWeb/servlet/CalandraRedirect?temp=6\&proj=PortalIBOPE $\underline{\text { \&pub}=\mathrm{T} \& \text { nome }=\text { home } \text { materia \&db=caldb\&docid }=092582 \mathrm{CC} 36 \mathrm{D} 2 \mathrm{FBFB} 8325784800405 \mathrm{FB}}$ $\underline{8}$

Jacobs, L.F. \& Limant, E.R. (1991). Grey squirrels remember the locations of buried nuts. Anim. Behav., 41, 103-110.

Jacobs, R.A., \& Kruschke, J.K. (2011) Bayesian learning theory applied to human cognition. Wiley Interdisciplinary Reviews: Cognitive Science, 2(1), 8-21.

Johnson, J. \& Powell, P. (1994). Decision making, risk and gender: Are managers different? British Journal of Management, 5, 123-138.

Kacelnik, A. \& Bateson, M. (1996). Risky theories: The effects of variance on foraging Decisions. American Zoologist, 36(4), 343-402.

Kahn, B.E. \& Sarin, R.K. (1988). Modeling ambiguity in decision under uncertainty. Journal of Consumer Research, 15, 265-272.

Kahneman, D., \& Tversky, K. (1979). Prospect Theory: An Analysis of Decision under Risk. Econometrica, XLVII, 263-291.

Keough, K.A., Zimbardo, P.G. \& Boyd, J.N. (1999). Who's smoking, drinking, and using drugs? Time perspective as a predictor of substance use. Basic and Applied Social Psychology, 21, 149-164. 
Kirby, K. N., \& Marakovic, N. N. (1995). Modeling myopic decisions: Evidence for hyperbolic delay discounting within subjects and amounts. Organizational Behavior and Human Decision Processes. 64, 22-30.

Kirby. K. N., Petry, N.M. \& Bickel, W.K. (1999). Heroin addicts have higher discount rates for delayed rewards than non-drug-using controls. J Exp Psychol Gen., 128, 78-87.

Kirby, K. N. \& Santiesteban, M. (2003). Concave utility, transaction costs, and risk in measuring discounting of delayed rewards. J. Exp. Psychol. Learn. Mem. Cogn, 29, 66-78.

Kollins, S. H. (2003). Delay discounting is associated with substance abuse in college students. Addictive Behaviors, 28, 1167-1173.

Levin, I., Snyder, M., \& Chapman, D., (1988). The interaction of experiential and situational factors and gender in a simulated risky decision-making task. The Journal of Psychology, 122 (2), 173-181.

Levine, R.V. \& Norenzayan, A. (1999). The pace of life in 31 countries. Journal of crosscultural psychology, 30(2), 178-205.

Logue, A. W., \& Anderson, Y. D. (2001). Higher education administrators: When the future does not make a difference. Psychological Science, 12, 276-281

Malkoc, S. A. \& Zauberman, G. (2006). Deferring versus expediting consumption: the effect of outcome concreteness on sensitivity to time horizon. Journal of Marketing Research, 43, 618-27.

Metcalfe, J., \& Wiebe, D. (1987). Intuition in insight and noninsight problem solving. Memory \& Cognition, 15, 238-246.

Milfont, T.L.; Andrade, P.R.; Belo, R.P.; \& Pessoa, V.S. (2008) Testing Zimbardo Time Perspective Inventory in a brazilian sample. Revista Interamericana de Psicologia, 42 (1), 4958.

Mischel, W., Shoda, Y., \& Rodriguez, M. L. (1989). Delay of gratification in children. Science, 244, 933-938. 
Parfit, D. (1971) Personal Identity. Philosophical Review, 80, 3-27.

Parfit, D. (1987). Reasons and Persons. Clarendon Press: Oxford.

Petry,N.M., \& Casarella, T. (1999). Excessive discounting of delayed rewards in substance abusers with gambling problems. Drug and Alcohol Dependence, 56, $25-32$.

Pinker, S. (2005). So how does the mind work? Mind \& Language, 20, 1-24.

Powell, M. \& Ansic, D. (1997). Gender differences in risk behaviour in financial decisionmaking: An experimental analysis. Journal of Economic Psychology, 18, 605-628.

Rachlin, H. Castrogiovanni, A., \& Cross, D. (1987) Probability and delay in commitment. Journal of the Experimental Analysis of Behavior. 48, 347-353.

Read, D., Frederick, S. Orsel, B. \& Rahman, J. (2005). Four Score and Seven Years from Now: The Date/Delay Effect in Temporal Discounting. Management Science, 51, 1326-35.

Read, D. \& Roelfsma, P.H.M.P. (2003). Subadditive versus hyperbolic discounting: A comparison of choice and matching. Organizational Behavior and Human Decision Processes, 91(2), 140-153.

Reynolds, B., Karraker, K., Horn, K., \& Richards, J. B. (2003). Delay and probability discounting as related to different stages of adolescent smoking and non-smoking. Behavioural Processes, 64, 333-344.

Reynolds, B., Ortengren, A., Richards, J. B., \& De Wit, H. (2006). Dimensions of impulsive behavior: Personality and behavioral measures. Personality \& Individual Differences, 40, 305-315.

Richards, J. B., Mitchell, S. H., de Wit, H., \& Seiden, L.S. (1997). Determination of discount functions in rats with an adjusting-amount procedure. Journal of the Experimental Analysis of Behavior, 67, 353-366. 
Rubenstein, C. (1998). The sacrificial mother. New York: Hypenon.

Schelling, T.C. (1984). Self-command in practice, in policy, and in a theory of rational choice. The American Economic Review, 74, 1-11.

Sexton, D., \& Bowman-Upton, N. (1990). Female and male entrepreneurs: Psychological characteristics and their role in gender related discrimination. Journal of Business Venturing, 5 (1), 29-36.

Shoda, Y., Mischel, W. \& Peake, P.K. (1990). Prediscting adolescent cognitive and selfregulatory competencies from preschool delay of gratification. Developmental psychology, 26, 978-986.

Silverman, I. W. (2003). Gender differences in delay of gratification: A meta-analysis. Sex Roles, 49, 451-463.

Simon, H. A. (1957). Models of Man. New York: John Wyler and Sons.

Simonsohn, U. (2009). Direct risk aversion: Evidence from risky prospects valued below their worst outcome. Psychological Science, 20, 686-692.

Sistrunk, F. \& McDavid, J. W. (1971) Sex variable in conforming behavior. Journal of Personality and Social Psychology, 17 (2), 200-207.

Soman, D. (1998). The Illusion of Delayed Incentives: Evaluating Future Effort-Monetary Transactions, Journal of Marketing Research, 35(4), 427-237.

Soman, D. Ainslie, G., Frederick, S., Li, X., Lynch, J., Moreau, P., et al. (2005) The Psychology of Intertemporal Discounting: Why are Distant Events Valued Differently from Proximal Ones? Marketing Letters, 16 (3/4), 347-360.

Stanovich, K. E., West, R.F. (2008). On the Relative Independence of Thinking Biases and Cognitive Ability. Journal of Personality and Social Psychology, 94 (4), 672- 695. 
Steinberg, L. Graham, S., O’Brien, L., Woolard, J., Cauffman, E. \& Banich, M. (2009) Age Differences in Future Orientation and Delay Discounting. Child Development, 80 (1), 28 - 44.

Strack, F., Martin, L. L., \& Schwarz, N. (1988). Priming and communication: Social determinants of information use in judgments of life satisfaction. European Journal of Social Psychology, 18, 429-442.

Strotz, R.H. (1955). Myopia and inconsistency in dynamic utility maximization. Review of Economic Studies, 23(3), 165-180.

Thaler, R. H. (1981). Some Empirical Evidence on Dynamic Inconsistency. Economic Letters, 8, 201-207.

Thaler, R.H. (2000). From Homo Economicus to Homo Sapiens. Journal of Economic Perspectives, 14 (1), 133-141.

Tooby, J., \& Cosmides, L. (1992). The psychological foundations of culture. Em J. H. Barkow, L. Cosmides, \& J. Tooby (Eds.), The adapted mind: Evolutionary psychology and the generation of culture (19-136). New York: Oxford University Press.

Tooby, J. \& DeVore, I. (1987). The reconstruction of hominid behavioral evolution through strategic modeling. In W.G. Kinsey (Ed.), The evolution of primate behavior: Primate models. 183-237. New York: SUNY University Press.

Trope, Y. \& Liberman, N. (2003). Temporal Construal. Psychological Review, 110 (3), 403421.

Tversky, A. \& Kahneman, D. (1974). Judgment under uncertainty: Heuristics and Biases. Science, 185, 1124-1131.

Tversky, A. \& Kahneman, D. (1983). Extensional versus intuitive reasoning: The conjunction fallacy in probability judgment. Psychological Review, 90, 293-315.

Tversky, A., S. \& Sattath, P. \& Slovic. (1988). Contingent weighting in judgment and choice. Psychological Review, 95(3), 371-384. 
Weber, E. U., Shafir, S. \& Blais, A. (2004). Predicting risk-sensitivity in humans and lower animals: Risk as variance or coefficient of variation. Psychological Review, 111, 430-445.

Weller, R.E., Cook III, E.W., Avsar, K.B. \& Cox, J.E. (2008). Obese women show greater delay discounting than healthy-weight women. Appetite, 51, 563-569.

Wills, T.A.; Sandy, J.M. \& Yaeger, A.M. (2001). Time perspective and early-onset substance use: A model based on stress-coping theory. Psychology of Addictive Behaviors 15, 118-125.

Zauberman, G.; Kim, B.K.; Malkoc, S.A. \& Bettman, J.R. (2009) Discounting Time and Time Discounting: Subjective Time Perception and Intertemporal Preferences. Journal of Marketing Research, XLVI, 543-556.

Zimbardo, P. G. \& Boyd, J.N. (1999). Putting Time in Perspective: A Valid, Reliable Individual-Differences Metric. Journal of Personality and Social Psychology, 77, 1271-88.

Zimbardo, P. G. \& Boyd, J. N. (2008). The time paradox: the new psychology of time that will change your life. New York: Free Press.

Zimbardo, P., Boyd, J., \& Keogh, K. (1999). Who's smoking, drinking, and using drugs? Time perspective as a predictor of substance use. Basic \& Applied Psychology, 21, 149-165.

Zimbardo, P.G., Keough, K.A. \& Boyd, J.N. (1997) Present time perspective as a predictor of risky driving. Personality and Individual Differences, 23, 1007-1023.

Zuckerman, M. (1971). Dimensions of sensation seeking. Journal of Consulting and Clinical Psychology, 36(1), 45-52.

Zuckerman, M.; Eysenck, S. B. \& Eysenck, H. J. (1978) Sensation seeking in England and America: Cross-cultural, age, and sex comparisons. Journal of Consulting and Clinical Psychology, 46(1), 139-149. 


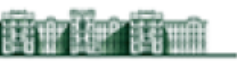 MEDICINA \\ TSP \\ COMITÊ DE ÉTICA EM PESQUISA}

\section{APROVAÇÃo}

O Comitê de Ética em Pesquisa da Faculdade de Medicina da Universidade de São Paulo, em sessão de 25/o5/2011, APROVOU o Protocolo de Pesquisa no 144/11 intitulado: "PERCEPÇÃO DE TEMPO E DESCONTO DO FUTURO” apresentado pelo Instituto de Psicologia.

Cabe ao pesquisador elaborar e apresentar ao CEPFMUSP, os relatórios parciais e final sobre a pesquisa (Resolução do Conselho Nacional de Saúde $n^{\circ}$ 196, de 10/10/1996, inciso IX.2, letra "c").

Pesquisador (a) Responsável: Vera Silvia Raad Bussab

Pesquisador (a) Executante: Isabella Bertelli Cabral dos Santos

CEP-FMUSP, 26 de Maio de 2011.

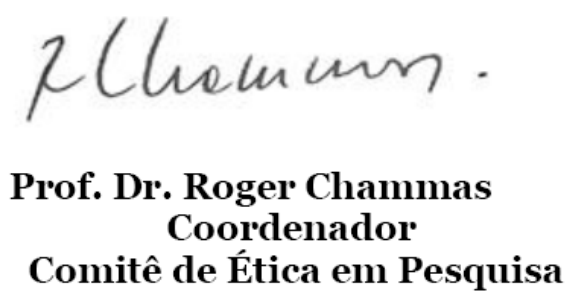




\section{ANEXO B}

\section{Termo de consentimento livre e esclarecido}

Eu, Isabella Bertelli Cabral dos Santos, sou pós-graduanda em Psicologia Experimental no Instituto de Psicologia da Universidade de São Paulo (Av. Professor Mello Moraes, 1721, Cidade Universitário - São Paulo, SP - fone (11) 3091-4357) e estou efetuando a presente pesquisa de mestrado, orientada pela Prof ${ }^{a}$. Titular Dra. Vera Silvia Raad Bussab.

O objetivo da pesquisa é estudar o comportamento monetário. O questionário é autoexplicativo e consiste em algumas perguntas que envolvem decisões em situações que envolvem o uso de dinheiro. Dados demográficos, como idade, sexo, e outros também serão acessados.

Não há respostas certas ou erradas, pois não estamos julgando ninguém, apenas queremos saber como os respondentes são, independentemente de julgamentos de valor. Gostaria que cada participante se empenhasse em responder da forma mais sincera e espontânea possível, sempre prestando atenção ao preenchimento de cada questão.

O questionário é anônimo, voluntário e sigiloso, e não produzirá qualquer dano, gasto, nem desconforto físico para os respondentes. Os dados serão tratados em grupo e de maneira compatível com a Ética da Pesquisa em Psicologia. O comitê responsável pela aprovação dessa pesquisa é o Comitê de Ética em Pesquisa FMUSP, cujo endereço eletrônico é http://www.fm.usp.br/cep .

A participação leva apenas alguns minutos e a adesão à pesquisa é voluntária, sendo possível a desistência a qualquer momento sem que haja nenhum prejuízo. A pesquisadora está à disposição para responder quaisquer dúvidas que surjam antes, durante e depois da pesquisa. Caso os participantes tenham interesse no relatório da pesquisa, estamos disponibilizando nossos endereços eletrônicos: vsbussab@usp.br e isabella.santos@usp.br , endereço e telefone (Av. Prof. Mello Moraes, 1721, Bloco F, sala 35, Cidade Universitária São Paulo, SP- fone; (11) 3097-4448 Ramal 35.

*Obrigatório

\section{Consentimento}

Você aceita participar dessa pesquisa? * 
$\square$ Sim, eu concordo em participar da pesquisa sobre comportamento monetário e declaro estar ciente que dados do questionário terão apenas fins científicos, que é anônimo e que eu posso desistir a qualquer momento da pesquisa.

$\square$ Não, não concordo.

\section{Dados Demográficos}

\section{1) Qual seu sexo?}

( ) Feminino

( ) Masculino

1.2) Qual a sua idade?

1.3) Qual o seu nível de escolaridade?

( ) Ensino fundamental incompleto

( ) Ensino fundamental completo

( ) Ensino médio

( ) Técnico

( ) Superior

( ) Pós-graduação

4) Qual a sua atual situação amorosa?

( ) Solteiro (a)

( ) Ficando 
( ) Namorando

( ) Casado (a)

( ) Separado (a)/ Divorciado (a)

( ) Viúvo (a)

5) Você tem filhos?

( ) Sim

( ) Não

6) Se sim, quantos?

7) Em que dia você faz aniversário? (Essa pergunta é somente para separar as quatro condições experimentais, de modo que haja uma um número de pessoas semelhante em cada uma delas)

( ) Do dia 01 ao dia 07 (condição experimental 1)

( ) Do dia 08 ao 14 (condição experimental 2)

( ) Do dia 15 ao 22 (condição experimental 3)

( ) Do dia 23 ao 31 (condição experimental 4)

8) Suponha que você ganhou um cupom de vale compras no valor de 100,00 reais. O cupom é válido a partir de hoje. Qual teria que ser o valor mínimo desse cupom para que você esperasse noventa dias* para poder usá-lo?

(*ou três meses, ou uma data, ou um feriado, dependendo da condição experimental) 
9) Quão distante você considera a duração entre hoje e noventa dias?

$\begin{array}{llllllllll}1 & 2 & 3 & 4 & 5 & 6 & 7 & 8 & 9 & 10\end{array}$

Muito próximo

Muito distante

10) Você preferiria ganhar $R \$ 50,00$ com certeza ou ter $50 \%$ de chance de ganhar $R \$$ 800,00 ?

( ) Preferiria ganhar R\$ 50,00 com certeza

( ) Preferiria ter a chance de $50 \%$ de ganhar $\mathrm{R} \$ 800,00$

12) Você preferiria ganhar $R \$ 150,00$ com certeza ou ter $50 \%$ de chance de ganhar $R \$$ 800,00 ?

( ) Preferiria ganhar R\$150,00 com certeza

( ) Preferiria ter a chance de $50 \%$ de ganhar $\mathrm{R} \$ 800,00$

13) Você preferiria ganhar $\mathrm{R} \$ 200,00$ com certeza ou ter $50 \%$ de chance de ganhar $\mathrm{R} \$$ 800,00 ?

( ) Preferiria ganhar R\$200,00 com certeza

( ) Preferiria ter a chance de $50 \%$ de ganhar $\mathrm{R} \$ 800,00$

14) Você preferiria ganhar $R \$ 250,00$ com certeza ou ter $50 \%$ de chance de ganhar $R \$$ 800,00 ?

( ) Preferiria ganhar R\$250,00 com certeza

( ) Preferiria ter a chance de $50 \%$ de ganhar $\mathrm{R} \$ 800,00$ 
15) Você preferiria ganhar $\mathrm{R} \$ 300,00$ com certeza ou ter $50 \%$ de chance de ganhar $\mathrm{R} \$$ 800,00 ?

( ) Preferiria ganhar R\$300,00 com certeza

( ) Preferiria ter a chance de $50 \%$ de ganhar $\mathrm{R} \$ 800,00$

16) Você preferiria ganhar $\mathrm{R} \$ 350,00$ com certeza ou ter $50 \%$ de chance de ganhar $\mathrm{R} \$$ 800,00 ?

( ) Preferiria ganhar R\$350,00 com certeza

( ) Preferiria ter a chance de $50 \%$ de ganhar $\mathrm{R} \$ 800,00$

Nas questões a seguir, você deverá verificar quanto que cada frase tem a ver com você.

17) Correr riscos evita que minha vida se torne chata.

Nada a ver comigo Tudo a ver comigo

$$
\begin{array}{lllll}
1 & 2 & 3 & 4 & 5
\end{array}
$$

18) Completo meus projetos na hora certa através de progressos contínuos.

Nada a ver comigo Tudo a ver comigo

$\begin{array}{lllll}1 & 2 & 3 & 4 & 5\end{array}$

19) Tomo decisões no impulso do momento.

Nada a ver comigo Tudo a ver comigo

$\begin{array}{lllll}1 & 2 & 3 & 4 & 5\end{array}$


20) Para mim é mais importante aproveitar a jornada da vida do que focalizar apenas o destino.

Nada a ver comigo

Tudo a ver comigo

$\begin{array}{lllll}1 & 2 & 3 & 4 & 5\end{array}$

21) Cumprir os prazos para amanhã e fazer outros trabalhos necessários vêm antes da diversão noturna.

Nada a ver comigo

Tudo a ver comigo

$\begin{array}{lllll}1 & 2 & 3 & 4 & 5\end{array}$

22) Pego-me sendo levado (a) pela excitação do momento.

Nada a ver comigo Tudo a ver comigo

$\begin{array}{lllll}1 & 2 & 3 & 4 & 5\end{array}$

23) Acredito que encontrar com amigo (as) para festejar é um dos prazeres mais importantes da vida.

Nada a ver comigo Tudo a ver comigo

$\begin{array}{lllll}1 & 2 & 3 & 4 & 5\end{array}$

24) Quando quero alcançar algo, estabeleço objetivos e considero formas específicas para atingi-los.

Nada a ver comigo

Tudo a ver comigo

$\begin{array}{lllll}1 & 2 & 3 & 4 & 5\end{array}$

25) Eu sinto que é mais importante aproveitar o que se está fazendo do que fazer as coisas no prazo.

Nada a ver comigo Tudo a ver comigo

$\begin{array}{lllll}1 & 2 & 3 & 4 & 5\end{array}$ 
26) Sempre existirá tempo para colocar meu trabalho em dia.

Nada a ver comigo

Tudo a ver comigo

$\begin{array}{lllll}1 & 2 & 3 & 4 & 5\end{array}$

27) Quando escuto minhas músicas favoritas, perco toda a noção de tempo.

Nada a ver comigo Tudo a ver comigo

$\begin{array}{lllll}1 & 2 & 3 & 4 & 5\end{array}$

28) Cumpro minhas obrigações com amigos e autoridades no prazo.

Nada a ver comigo Tudo a ver comigo

$\begin{array}{lllll}1 & 2 & 3 & 4 & 5\end{array}$

29) Corro riscos para tornar minha vida excitante.

Nada a ver comigo Tudo a ver comigo

$\begin{array}{lllll}1 & 2 & 3 & 4 & 5\end{array}$

30) Prefiro amigos (as) que são espontâneos àqueles (as) que são previsíveis.

Nada a ver comigo Tudo a ver comigo

$\begin{array}{lllll}1 & 2 & 3 & 4 & 5\end{array}$

31) Não me preocupo se as coisas não forem feitas dentro do prazo.

Nada a ver comigo Tudo a ver comigo

$$
\begin{array}{lllll}
1 & 2 & 3 & 4 & 5
\end{array}
$$

32) Faço as coisas impulsivamente.

Nada a ver comigo Tudo a ver comigo 


$\begin{array}{lllll}1 & 2 & 3 & 4 & 5\end{array}$

33) Aceito cada dia como ele é, ao invés de tentar planejá-lo.

Nada a ver comigo Tudo a ver comigo

$\begin{array}{lllll}1 & 2 & 3 & 4 & 5\end{array}$

34) Idealmente, viveria cada dia da minha vida como se fosse o último.

Nada a ver comigo Tudo a ver comigo

$$
\begin{array}{lllll}
1 & 2 & 3 & 4 & 5
\end{array}
$$

35) Acredito que o dia da pessoa deva ser planejado no início de cada manhã.

Nada a ver comigo Tudo a ver comigo

$$
\begin{array}{lllll}
1 & 2 & 3 & 4 & 5
\end{array}
$$

36) Gosto que minhas relações íntimas sejam apaixonadas.

Nada a ver comigo Tudo a ver comigo

$\begin{array}{lllll}1 & 2 & 3 & 4 & 5\end{array}$

37) Fico chateado (a) quando me atraso para meus compromissos.

Nada a ver comigo Tudo a ver comigo

$\begin{array}{lllll}1 & 2 & 3 & 4 & 5\end{array}$

38) Frequentemente sigo mais meu coração do que minha razão.

Nada a ver comigo Tudo a ver comigo

$$
\begin{array}{lllll}
1 & 2 & 3 & 4 & 5
\end{array}
$$

39) Antes de tomar uma decisão eu peso os custos e benefícios. 
Nada a ver comigo Tudo a ver comigo

$\begin{array}{lllll}1 & 2 & 3 & 4 & 5\end{array}$

40) Permaneço trabalhando em tarefas difíceis e desinteressantes se elas me ajudarem a seguir em frente.

Nada a ver comigo Tudo a ver comigo

$\begin{array}{lllll}1 & 2 & 3 & 4 & 5\end{array}$

41) Sou capaz de resistir às tentações quando sei que existe trabalho a ser feito.

Nada a ver comigo Tudo a ver comigo

$\begin{array}{lllll}1 & 2 & 3 & 4 & 5\end{array}$

42) Tento viver minha vida tão intensamente quanto possível, um dia de cada vez.

Nada a ver comigo Tudo a ver comigo

$$
\begin{array}{lllll}
1 & 2 & 3 & 4 & 5
\end{array}
$$

43) Faço listas das coisas que tenho que fazer.

Nada a ver comigo Tudo a ver comigo

$\begin{array}{lllll}1 & 2 & 3 & 4 & 5\end{array}$

44) É importante vivenciar experiências estimulantes em minha vida.

Nada a ver comigo Tudo a ver comigo

$\begin{array}{lllll}1 & 2 & 3 & 4 & 5\end{array}$

Muito obrigado por sua participação! 
